Portland State University

PDXScholar

\title{
Stratigraphy and structure of the southeast part of the Portland Basin, Oregon
}

Kenneth E. Lite Jr.

Portland State University

Follow this and additional works at: https://pdxscholar.library.pdx.edu/open_access_etds

Part of the Geology Commons, and the Stratigraphy Commons

Let us know how access to this document benefits you.

\section{Recommended Citation}

Lite, Kenneth E. Jr., "Stratigraphy and structure of the southeast part of the Portland Basin, Oregon" (1992). Dissertations and Theses. Paper 4382.

https://doi.org/10.15760/etd.6266

This Thesis is brought to you for free and open access. It has been accepted for inclusion in Dissertations and Theses by an authorized administrator of PDXScholar. Please contact us if we can make this document more accessible: pdxscholar@pdx.edu. 
AN ABSTRACT OF THE THESIS OF Kenneth E. Lite Jr. for the degree of Master of Science in Geology presented May 1, 1992.

Title: Stratigraphy and Structure of the southeast part of the Portland Basin, Oregon.

APPROVED BY THE MEMBERS OF THE THESIS COMMITTEE:

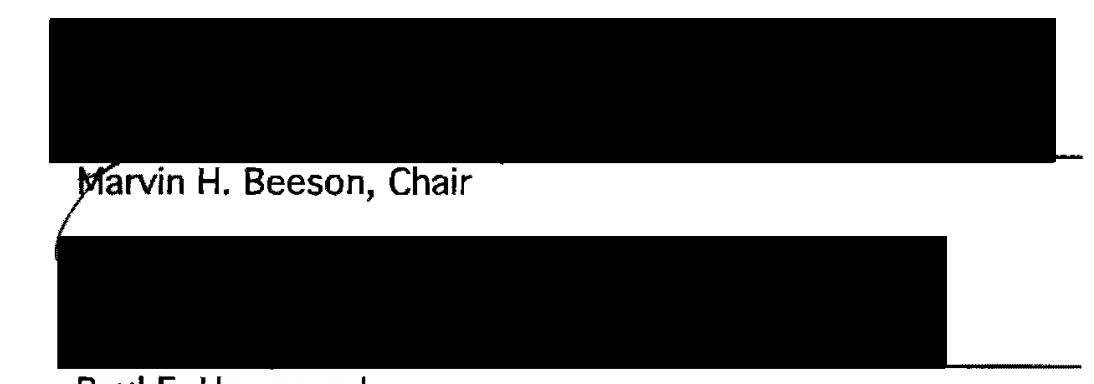

Paul E. Hammond
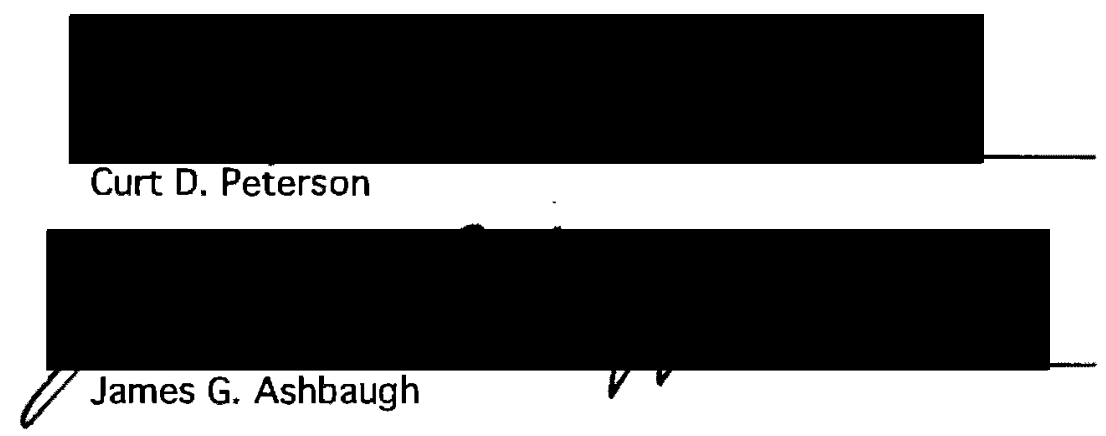

The southeast part of the Portland Basin has been previously described by other investigators. However, little detailed information existed on the depositional relationships between the units, the various sedimentary facies, or the origin of many of the units.

Over 200 samples from surface exposures and drill cuttings were microscopically examined. Geochemical analyses were conducted on fifty bulk samples of 
volcanic and sedimentary materials. Forty-four samples were analyzed for trace elements using instrumental neutron activation analysis. Twenty-six samples were analyzed for major elements by Washington State University staff using x-ray fluorescence techniques.

Grande Ronde Basalt flows of the Columbia River Basalt Group are the oldest rocks within the study area. The Grande Ronde flows are overlain by Ginkgo, Sand Hollow, Sentinel Gap, and Lyons Ferry units of the Frenchman Springs Member of Wanapum Basalt. The Columbia River Basalt Group is overlain throughout the study area by up to 215 meters of massive to thinly laminated clay, silt, and fine sand of the lower Troutdale member. The lower Troutdale member is equivalent to the Sandy River Mudstone. The lower Troutdale member is overlain by the upper Troutdale member. The upper Troutdale member is composed of two facies in the study area, a quartzite bearing pebble to cobble conglomerate in a matrix of micaceous, arkosic sand and a medium to coarse grained vitric and lithic sand with occasional pebble to cobble clasts. The Boring Lava is intercalated with and overlies the upper Troutdale member within the study area. One Boring Lava vent was identified during this investigation. Up to 65 meters of post-Troutdale deposits occur within the study area. The post-Troutdale unit is distinguished from upper Troutdale material by an abundance of coarse grained volcanic clasts, a greater degree of weathering, and a lack of sorting. Post-Troutdale sediments locally contain mudflows and debris flows.

Geochemical data indicate two sources for the sedimentary units. Columbia River Basin derived material exhibit higher elemental abundances of thorium, lanthanum, and silica. Vitric and lithic sediments of the upper Troutdale member and volcaniclastic material from the post-Troutdale deposits are similar to some Cascade Range and Portland Basin volcanic units. Vitric and lithic sediments of the upper Troutdale member cluster in two chemical groups. One group is similar to Pliocene Cascade Range 
basalt units. The basalt-like samples exhibit scandium values from 31 and $36 \mathrm{ppm}$, and silica from 49 to 53 percent. The second group is similar to Portland Basin derived basaltic andesite Boring Lavas. Those samples have scandium values between 19 and 24 ppm, and silica between 54 and 58 percent. Debris flow deposits within the postTroutdale sediments have lower chromium and scandium, and higher silica than other volcanic derived material. The most likely source for much of the vitric and lithic sand and silt deposits in the study area are Pliocene volcanic deposits in the present day Bull Run and Sandy River drainages.

Major structural features within the southeast part of the Portland Basin include the Sandy River fault and the previously unrecognized Tickle Creek fault zone. The Sandy River fault displaces Columbia River Basalt units by approximately 245 meters. The Tickle Creek fault zone is composed of several short $(1 / 2-1 \mathrm{~km})$ northnorthwest, northwest, and northeast trending fault segments. One small northeast striking segment is identified as a left-lateral strike-slip fault. The Tickle Creek fault zone is interpreted as a right-lateral wrench fault. The structural features within the southeast part of the Portland Basin are collectively interpreted as part of a complex boundary zone within the Portland Basin pull-apart structure. 
STRATIGRAPHY AND STRUCTURE OF THE SOUTHEAST PART

OF THE PORTLAND BASIN, OREGON

$$
\text { by }
$$

KENNETH E. LITE JR.

A thesis submitted in partial fulfillment of the requirements for the degree of

\section{MASTER OF SCIENCE \\ in \\ GEOLOGY}

Portland State University

1992 
TO THE OFFICE OF GRADUATE STUDIES:

The members of the committee approve the thesis of Kenneth E. Lite Jr. presented May 1, 1992.

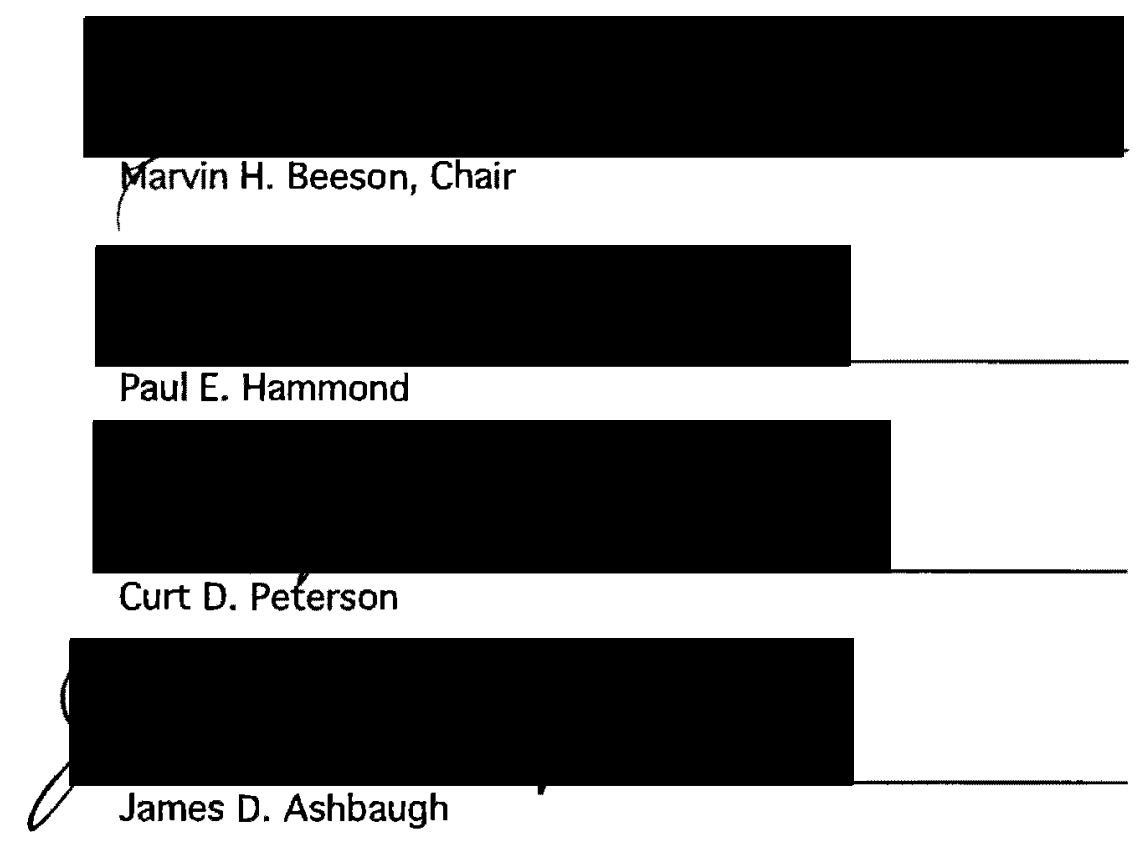

\section{APPROVED:}

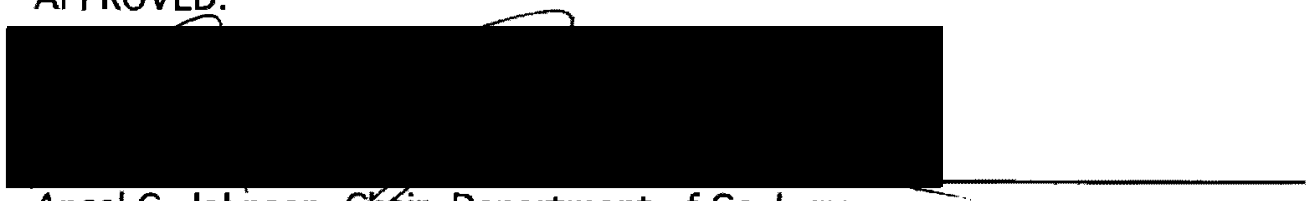

Ansel G. Johnson, Ghair, Department of Geology

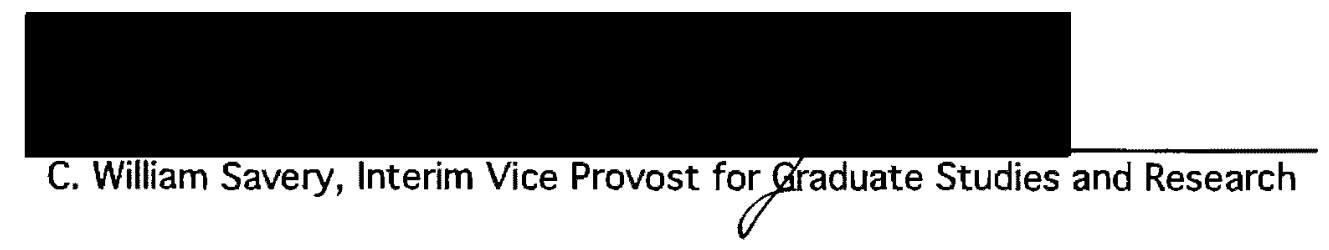




\section{ACKNOWLEDGEMENTS}

I greatly appreciate the support and encouragement received from my colleagues at the Oregon Water Resources Department. Special thanks are given to Mr. Fred Lissner and Mr. Karl Wozniak.

I also appreciate the support provided by the faculty, staff, and students of the Geology Department at Portland State University. Special thanks are given to my advisor, Dr. Marvin Beeson, for his guidance and assistance. I also thank Drs. Paul Hammond and Curt Peterson for reviewing the thesis and offering suggestions. Dr. Paul Hammond also contributed time to discussions of the thesis.

Funding for geochemical analyses were provided by a grant from the Oregon Department of Geology and Mineral Industries. Mr. lan Madin of the Oregon Department of Geology and Mineral Industries staff also provided many discussions in the field.

I also thank Karen and Kendra for their patience and understanding during the course of this study. 


\section{TABLE OF CONTENTS}

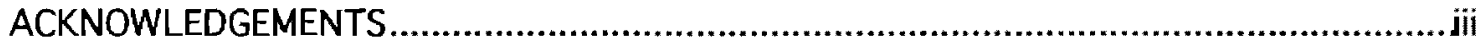

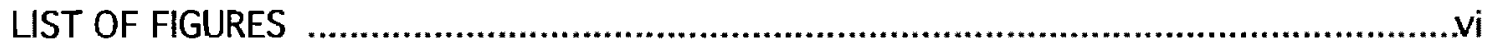

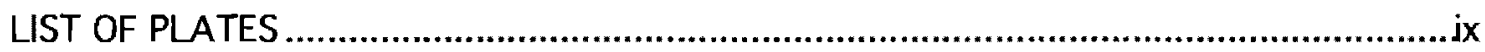

INTRODUCTION

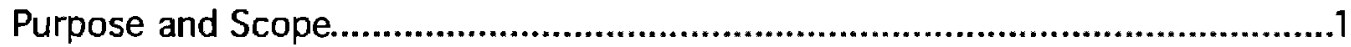

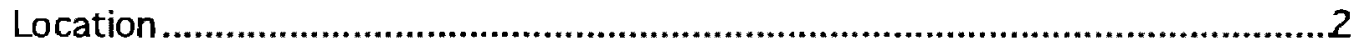

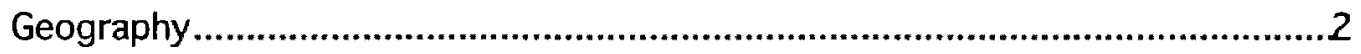

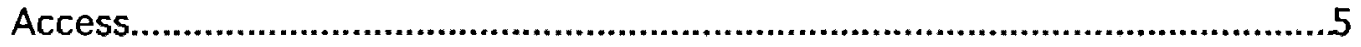

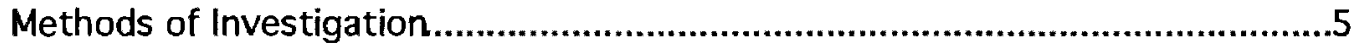

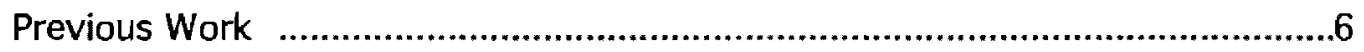

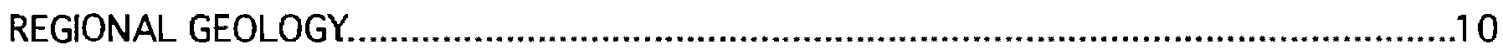

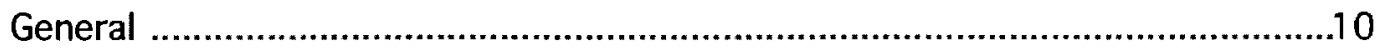

General Stratigraphy of the Portland Basin .....................................................10

Pre-Columbia River Basalt Group Units

Columbia River Basalt Group

Post-Columbia River Basalt Group Deposits

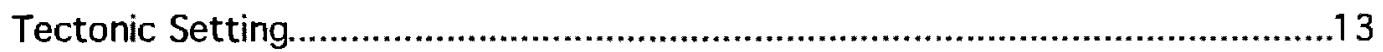

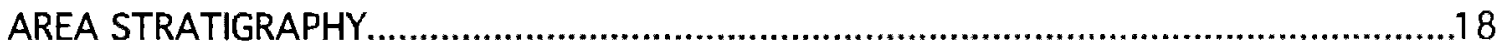

Columbia River Basalt Group ......................................................................18

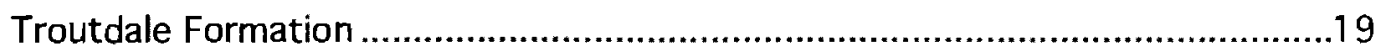




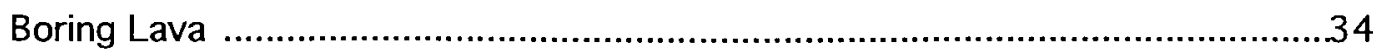

Post-Troutdale Sediments and Debris Flows …...........................................35

Chemical Analyses of Troutdale and Post-Troutdale Units ..............................39

Introduction

Chemical Groups

Possible Source Areas for the Sedimentary Units ..........................................44

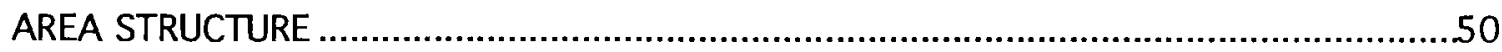

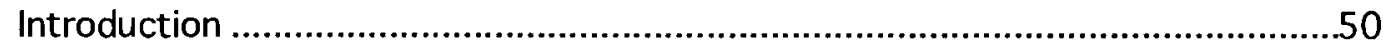

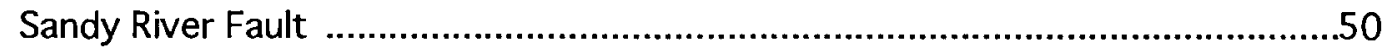

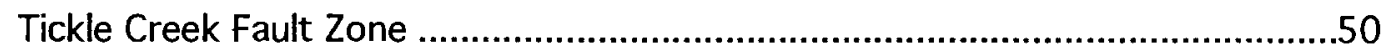

Other Faults

Structure Contour Map ................................................................................54

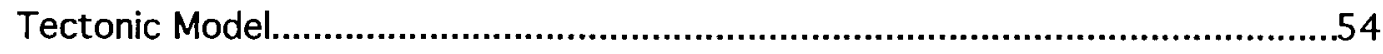

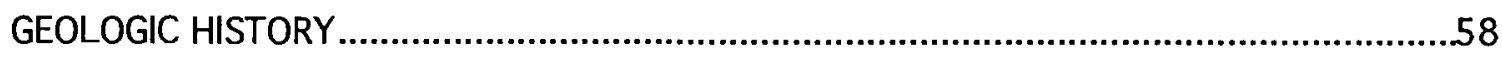

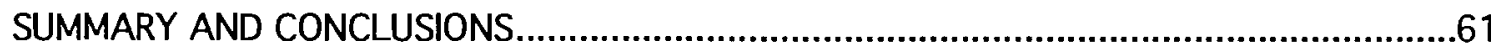

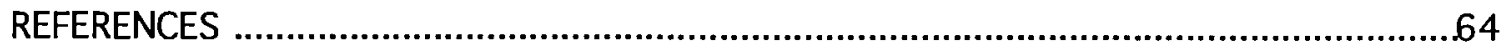

APPENDICES

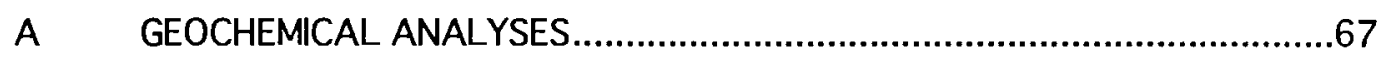

B STRATIGRAPHIC SECTIONS OF SAMPLED WELLS ................................76 


\section{LIST OF FIGURES}

PAGE

FIGURE

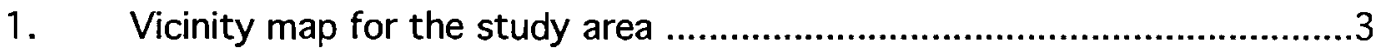

2. Location map for the study area...........................................................4

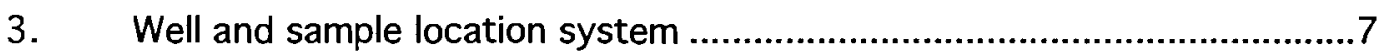

4. Tectonic map of the greater Portland area, modified from Tolan and

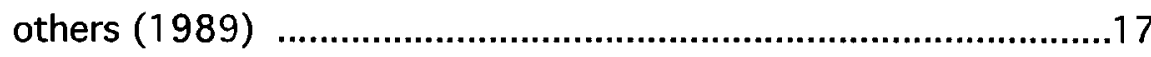

5. Comparison of Geologic Unit Nomenclature used for Portland Basin

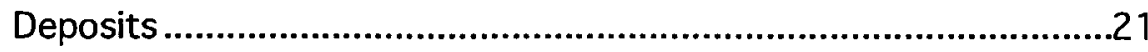

6. Massive to thinly laminated beds of the lower Troutdale member ............22

7. Contact between lower Troutdale member and Columbia River facies

of upper Troutdale member

8. Comparison of thorium vs chromium for lower Troutdale siltstone

(this study) and Sandy River Mudstone sediments.

9. Fine grained lower Troutdale-like sediments overlying Columbia

River facies upper Troutdale member within the N. Fork

Deep Creek drainage

10. Scandium vs chromium for lower Troutdale member and Columbia

River facies upper Troutdale sediments

11. Fine grained upper Troutdale vitric material overlying micaceous

silt and clay layer of the Columbia River facies of upper

Troutdale

12. Close-up of the same contact shown in Figure 11 
13. An $8 \mathrm{~cm}$ basalt clast within coarse grained vitric and lithic sand unit of the upper Troutdale member

14. Matrix supported basalt and quartzite clasts within vitric and lithic unit of the upper Troutdale member

15. Weathered, unsorted, clast supported sediments typical of the post-

Troutdale unit .36

16. Mudflow deposit within the post-Troutdale unit 38

17. Thorium versus $\mathrm{SiO}_{2}$ for all samples analyzed for major elements 41

18. Scandium versus $\mathrm{SiO}_{2}$ for all samples analyzed for major elements

19. Thorium versus scandium for all samples analyzed for major

elements .43

20. Comparison of the variations in selected chemical constituents for

the stratigraphic units

21. Scandium versus $\mathrm{SiO}_{2}$ for several Cascade volcanic units and

Portland Basin volcanic and vitric/lithic units 47

22. Small left-lateral strike-slip fault within the Columbia River

facies of the upper Troutdale member

23. Close-up along strike of the slickensided surface on the quarry

fault .53

24. Structure contour map of the top of the lower Troutdale member. 55

25. A comparison between a right-lateral wrench model and mapped

fault segments along the Tickle Creek fault zone. 56

26. Snyder well section .77

27. Wilson well section .78

28. Iseli Nursery well \#6 section 79

29. Surface Nursery well section .80 
30. Sobella Nursery well section .81

31. Krueger Nursery well section .82 


\section{LIST OF PLATES}

PLATE

1. Geology of the Sandy/Boring area, Clackamas County, Oregon

2. Geologic Cross Sections 


\section{INTRODUCTION}

\section{PURPOSE AND SCOPE}

Trimble $(1957,1963)$ defined or redefined several lithologic units within the Portland Basin. Those units include the Sandy River Mudstone, Boring Lava, and the Troutdale, Springwater, Walters Hill, Gresham, and Estacada Formations.

Trimble did not describe in detail the differences or depositional relationships between the various sedimentary units he defined. The distributions of different facies within the Troutdale Formation have not been defined. Little is known about the depositional relationship between different facies within the Troutdale Formation. Also, little is known about the depositional relationship between the Troutdale Formation and the Springwater Formation as described by Trimble (1963). Some debate exists as to whether the Springwater Formation is a separate stratigraphic unit or a different facies of the Troutdale Formation. The origin and distribution of several Sandy River Mudstone-like deposits within the Troutdale Formation are poorly understood. In addition, little is known about the origin of the Walters Hill Formation. Some questions exist as to whether the Walters Hill Formation is derived from Boring vents within the Portland Basin or from Cascade Range vents.

No structural features have been mapped in the sedimentary units. Presently, the only contact relationship within sedimentary units defined well enough to make structural interpretations is that between the Sandy River Mudstone and the Troutdale Formation.

The purpose of this study is to produce a geologic map of the deposits within the southeast part of the Portland Basin. The objectives are to: 1) interpret the 
depositional environment, sedimentary facies, and geometry of the sedimentary units;

2) obtain a better understanding of the origin of the Troutdale and post-Troutdale deposits; and 3) determine the extent, relative age, and amount of deformation of the sedimentary units.

\section{LOCATION}

The study area is located approximately $25 \mathrm{~km}$ east-southeast of Portland, Oregon within the southeast part of the Portland Basin (Figure 1). The area encompasses approximately $170 \mathrm{~km}^{2}$, and includes most of T1-2S, R3-4E, within northern Clackamas County, Oregon (Figure 2).

\section{GEOGRAPHY}

The Portland Basin is an elongate topographic low that is approximately $75 \mathrm{~km}$ long and $25 \mathrm{~km}$ wide. The Tualatin Mountains, which are primarily composed of Miocene age basalt flows of the Columbia River Basalt Group bound the basin on the west. The eastern boundary of the basin is composed of Oligocene to Pliocene age volcanic and volcaniclastic deposits of the Cascade Range. The Portland Basin is transected by two major rivers, the Willamette and the Columbia, and two tributary streams, the Clackamas and Sandy Rivers. All four rivers drain generally northwestward across the Basin.

The topography of the study area is dominated by a gentle northwest sloping surface which abuts the foothills of the Cascade Range. This surface is broken by the Boring Hills which occupy most of the northwest part of the study area, and several deeply incised drainages. Two drainages flow towards the northwest, while most of the others drain to the west or southwest. 


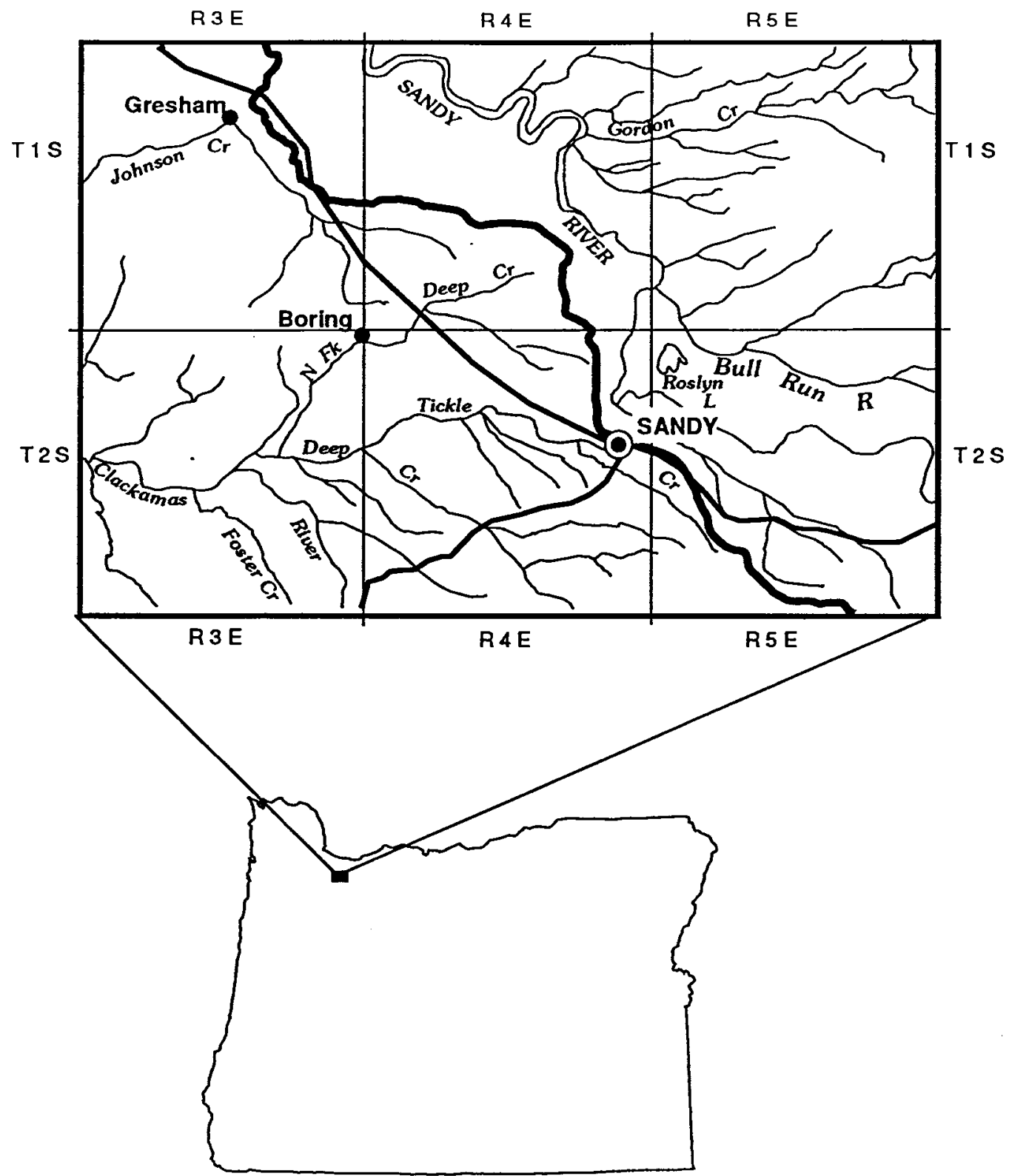

Figure 1. Vicinity map for the study area. 


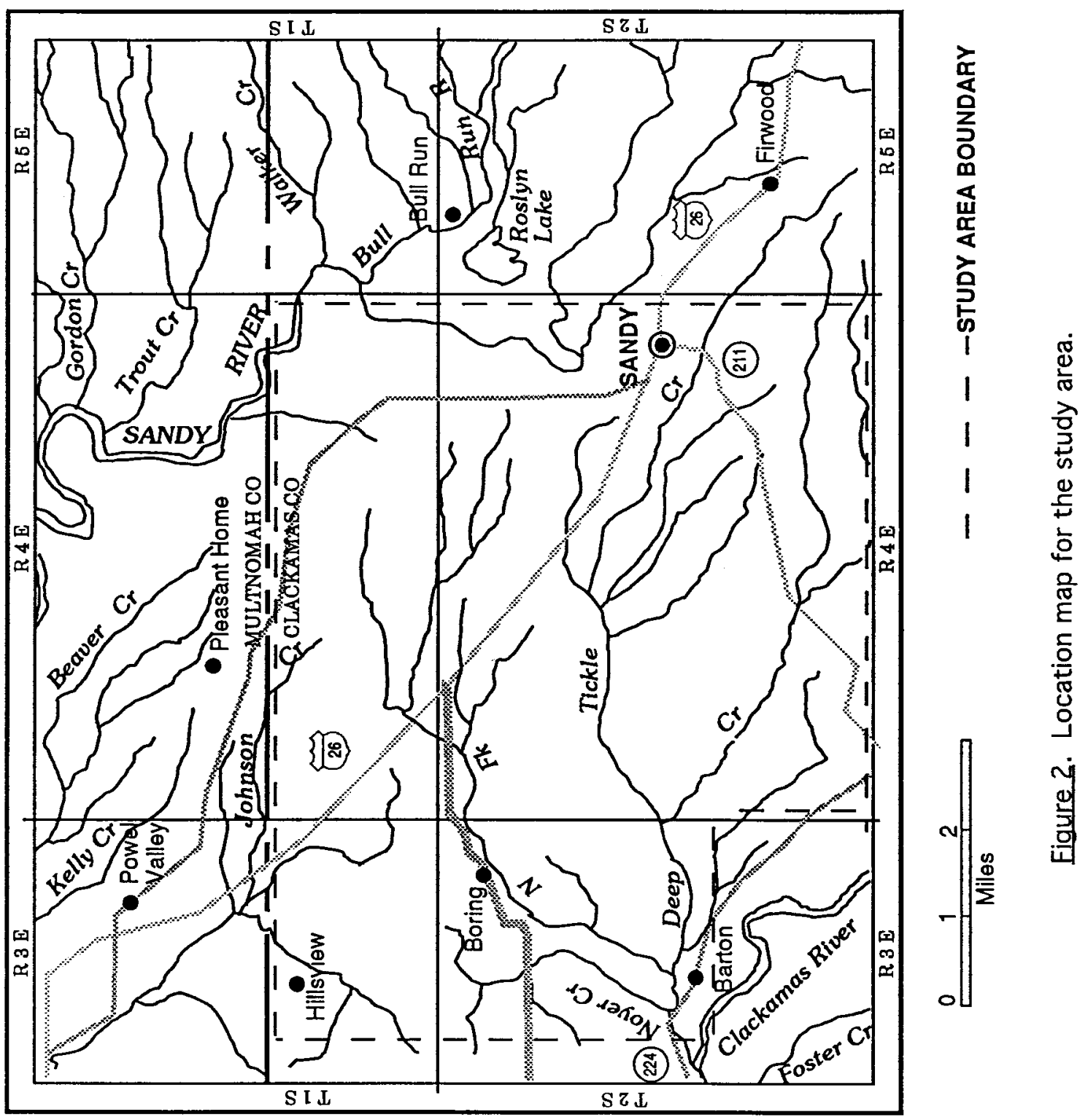


Elevations of the gently sloping surface range from approximately 1100 feet in the southeast, to about 500 feet in the northwest. The Boring Hills rise to approximately 1000 feet in elevation, whereas the lowest elevation of the incised drainages is about 150 feet.

\section{ACCESS}

Access to the study area is very good. U.S. Route 26 transects the area from the north to the southeast. State Highways 211 and 212 cross parts of the area. The highways, together with numerous county and private roads allow access to most of the study area. The large tributaries to the Clackamas and Sandy Rivers are accessible during the late summer months when streamflows are low.

\section{METHODS OF INVESTIGATION}

A number of investigative methods were used during this study including aerial photograph analysis; microscopic analysis of drill cuttings and hand samples; ground traverses and sampling; water well log interpretation; hydrologic data analysis; and geochemical analysis.

Areal photographs were used to field locate wells, map the geology, and locate field sampling points. A 1986 stereo coverage of black and white 1:31,000 scale airphotos were utilized.

Approximately 200 samples were examined with a plain light microscope. The samples included drill cutting from six water wells and representative hand samples from ground traverses.

Ground traverses and sampling were conducted along numerous roads and highways throughout the study area. In addition, traverses were made along parts of the 
Clackamas and Sandy Rivers as well as along Deep Creek, North Fork Deep Creek, Tickle Creek, Noyer Creek, and a number of unnamed tributaries.

Approximately 150 water well reports for field located wells were reviewed during this study. Numerous geologic cross-sections were constructed and examined using data from water well reports, drill cuttings, and ground traverses.

Hydrologic data were used to locate or confirm the presence of geologic features. Aquifer test results and well hydrographs were analyzed to confirm lithologic and structural boundary features.

Geochemical analyses were performed on fifty drill cutting and hand specimen samples. Instrumented neutron activation analysis was used to determine trace element abundances in forty-four fine grained sedimentary and volcanic samples (see Appendix A). Twenty-six of these samples were also analyzed for major element abundances by Washington State University staff at their X-ray Fluorescence Lab.

The map locations of various data points are referenced in the text by Township, Range, and Section. For example, a referenced location in T1S, R4E, section 28DAA is located in Township 1 South, Range 4 East, and Section 28. The letters following the section number indicate the location within the section as shown on Figure 3.

\section{PREVIOUS WORK}

The first geological descriptions within the study area were by Allen (1932). Allen described the occurrence of quartz [quartzite], basalt and andesite boulders in a tuffaceous or gritty matrix. He called the unit Troutdale Formation. Allen (1932) also described a "rotten" conglomerate he named the Deep Canyon Formation. The conglomerate is described as predominantly andesite with a few basalt clasts set in a coarse tuffaceous matrix (Allen, 1932). 


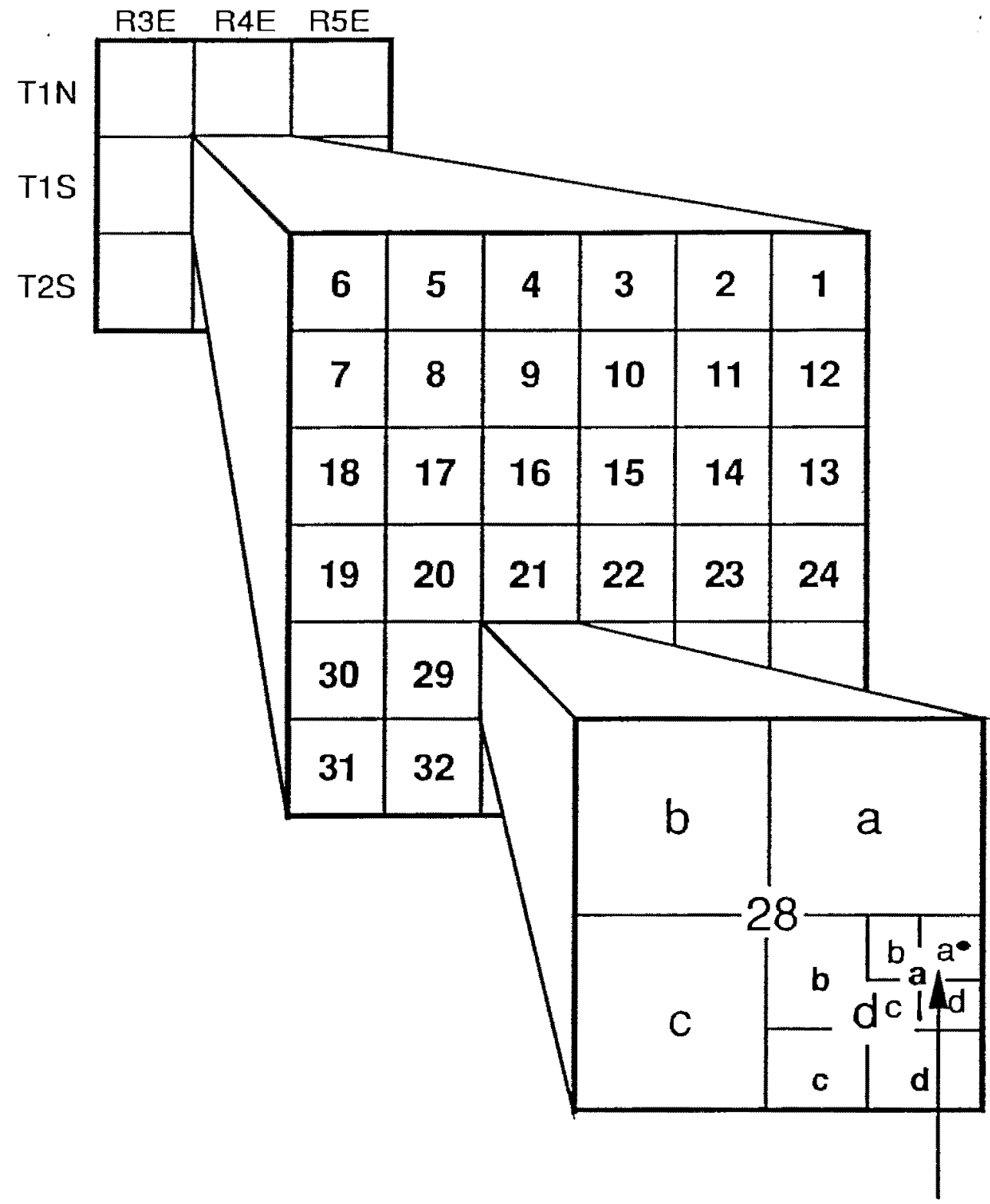

T1S, R4E, Section 28 DAA

Figure 3. Well and sample location system. 
The first geologic map of the study area was made by Treasher (1942). Within the study area, Treasher identified four lithologic units. Those units include the Troutdale Formation, Boring Lavas, Glacial Outwash, and Terrace Gravels. The Troutdale Formation as mapped by Treasher is a combination of Allen's Troutdale and Deep Canyon Formations.

The study area was next mapped by Trimble (1963) who identified seven lithologic units within the study area. The units identified by Trimble included the Sandy River Mudstone, Troutdale Formation, Walters Hill Formation, Boring Lava, Springwater Formation, Gresham Formation, and Estacada Formation. Trimble (1963) subdivided the Troutdale Formation as mapped by Treasher (1942) into the Sandy River Mudstone, Troutdale, Walters Hill, and Springwater Formations. Trimble (1963) mapped the glacial outwash unit of Treasher (1942) as the Gresham, Estacada, and in part, Springwater Formations.

Subsequent work encompassing the study area has been conducted by Foxworthy and others (1964), Hogenson and Foxworthy (1965), Allen (1975), Schlicker and Finlayson (1979), Leonard and Collins (1983), Beeson and others (1989), and Yelin and Patton (1991). Foxworthy and others (1964) published a groundwater data report for the east Portland area. Hogenson and Foxworthy (1965) published a summary of groundwater characteristics and conditions for the east Portland area. Allen (1975) discusses the origins and distribution of Boring Lava vents in the Portland area. Schlicker and Finlayson (1979) describe the geology and geologic hazards of northwestern Clackamas County. Leonard and Collins (1983) describe groundwater conditions in part of northern Clackamas County. Beeson and others (1989a) include the study area in a discussion of the regional distribution of the Columbia River Basalt Group in western Oregon. Yelin and Patton (1991) discuss their analysis of microseismic events within the Portland Basin and propose a seismotectonic model for 
the region. Investigations within the Portland area subsequent to Trimble (1963) mostly utilize the lithologic unit nomenclature proposed by Trimble.

A number of thesis studies have included part or all of the study area. Allen (1932) was the first to describe the stratigraphic units within the study area. An uncompleted thesis project by Darolyn Burch in 1980 includes geochemical data, petrographic data, paleomagnetic data, and interpretations of the Boring Lava within the Portland Basin and lower Columbia Gorge. Davis (1987) utilized gravity modeling to investigate the structure and genesis of the eastern margin of the Portland Basin. Beeson (1990) developed gravity models and maps in an analysis of the geology of the Portland Basin. 


\section{REGIONAL GEOLOGY}

\section{GENERAL}

The study area represents a relatively small part of a larger physiographic and geological feature called the Portland Basin. The Portland Basin has a complex tectonic history which includes millions of years of episodic volcanic and sedimentary deposition. An understanding of the regional stratigraphic and tectonic setting is necessary for an understanding of the geologic history of the thesis area.

\section{GENERAL STRATIGRAPHY OF THE PORTLAND BASIN}

\section{Pre-Columbia River Basalt Group Units}

The oldest geologic unit exposed in the Portland Basin is the Waverly Heights Basalt (Beeson and others, 1989b). The Waverly Heights Basalt are exposed near Milwaukie, Oregon in the southwest part of the Portland Basin. Trimble (1963) had erroneously mapped the exposures as Columbia River basalt. The Waverly Heights Basalt are chemically similar to the Tillamook Volcanics and have been radiometrically dated at approximately 40 million years (Beeson and others, 1989b).

\section{Columbia River Basalt Group}

The Portland area contains deposits of the Columbia River Basalt Group that may exceed 500 meters in thickness (Marvin Beeson, personal communication, 1989). The Columbia River Basalt Group flows overlie the Waverly Heights Basalt and Skamania Volcanics within the Portland Basin (Beeson and others, 1989b; Trimble, 1963). Columbia River Basalt Group flows originated from fissure eruptions in western Idaho, southeast Washington, and northwest Oregon between approximately $16.5 \mathrm{ma}$ and $6 \mathrm{ma}$ 
(Tolan and others, 1989). Only flows of the Grande Ronde Basalt and Wanapum Basalt are known to occur within the Portland area. (Beeson and others, 1989a). The flows entered the Portland area through a topographic low in the Miocene Cascade Mountains (Beeson and others, 1989a). The deposition of those units occurred between approximately 16.5 Ma and $15 \mathrm{ma}$ (Beeson and Tolan, 1989).

\section{Post-Columbia River Basalt Group Deposits}

The sedimentary units in the Portland Basin were first described at exposures which occur in the lower Columbia Gorge. Williams included the sediments as part of the Satsop Formation in 1916; Buwalda and Moore referred to them as the Hood River Formation in 1929 (Tolan, 1982). Hodge (1938) described the Troutdale Formation and named it after the community of Troutdale, Oregon.

The Troutdale Formation and other sedimentary and volcanic deposits were mapped and described within the Portland Basin by several workers between the early 1940's and early 1960's. Treasher (1942), mapped the areal extent of the sediments in the Portland area. He also mapped and named the Boring Lava within the Portland Basin.

Wilkinson and others (1946), mapped and described the Troutdale Formation near the northern terminus of the Portland Basin. They recognized a lower fine grained facies and an upper sand and gravel facies. Trimble (1963), divided the Troutdale Formation into the Troutdale Formation and Sandy River Mudstone. He made the distinction based on differences in lithology and genesis. He also mapped and named a number of post-Troutdale Formations in the Portland Basin including the Walters Hill, Springwater, Gresham, and Estacada Formations (Trimble, 1963). Mundorff (1964) also recognized coarse grained and fine grained components of the Troutdale Formation. He subdivided the Troutdale Formation into upper and lower members. 
Tolan and Beeson (1984), proposed that the Troutdale Formation be subdivided into upper and lower members, based on their work in the Bridal Veil area in the lower Columbia Gorge. The lower member is described as the ancestral Columbia River facies which consists mainly of quartzite bearing basaltic conglomerates and micaceous arkosic sandstone. The lower facies generally overlies the Rhododendron Formation or the Columbia River Basalt Group, except where it overlies the Sandy River Mudstone in the Portland Basin (Tolan and Beeson, 1984). According to Swanson (1986), the lower Troutdale member and the Sandy River Mudstone appear geochemically and petrographically similar.

The upper member consists of pebbly to cobbly vitric sandstones and basaltic conglomerate interbeds with locally derived clasts. The clasts contain high-alumina basalt from Boring Lavas or High Cascade lavas and occasional Columbia Basin derived material (Tolan and Beeson, 1984).

The thickness of post-Columbia River Basalt Group deposits in the basin is known at a number of locations, mainly near the basin margins. Two of the best known locations are the Ladd Well site near 39th and S.E. Glisan and the Hood Acres Well near the Sandy River. The total thickness of post-Columbia River Basalt Group deposits reported for the Ladd Well and Hood Acres Well are 427 meters and 376 meters, respectively. The Ladd Well data are based on records for a well constructed in 1885 and reported in Piper (1942). The Hood Acres Well was drilled and sampled for nursery irrigation use in 1985.

Most studies of the Portland Basin sediments have been at a reconnaissance level. Facies distributions within the sedimentary units in the Portland Basin has not been addressed in detail in the previous work. Trimble (1963) indicates a generally coarsening upward sequence from the Sandy River Mudstone through the Troutdale and the Springwater Formations. 
The age of the deposits in the Portland Basin are thought to range from 16 million to about 0.5 million years. The age range for most of the individual deposits are only approximately known. The age ranges include: Columbia River Basalt Group, $16 \mathrm{Ma}$ to 14.5 Ma; Rhododendron Formation, approximately $14 \mathrm{Ma}$ to $7 \mathrm{Ma}$; lower member of the Troutdale Formation (Sandy River Mudstone), approximately $13 \mathrm{Ma}$ to $6 \mathrm{Ma}$; upper member of the Troutdale Formation, approximately $6 \mathrm{Ma}$ to $2 \mathrm{Ma}$; and Boring Lava, approximately $3 \mathrm{Ma}$ to $0.5 \mathrm{Ma}$ (Beeson and Tolan, 1989, Marvin Beeson, personal communication, 1992).

\section{TECTONIC SEITING}

Prior to 1974 , the Portland Basin was considered a north-south trending synclinal low. Trimble (1963), described the structure in the Portland area as "simple", with broad synclines separated by equally broad anticlines. He referred to the occurrence of faulting as minor. Mundorff (1964), described the northern part of the basin as a broad downwarped structure. Mundorff (1964), also described a number of northwest and northeast trending faults along the eastern basin boundary. Most notably, he mentions a northwest trending fault near Lacamas Creek that offsets the Troutdale Formation.

In 1974, Benson and Donovan published a tectonic map of the Portland area. The map covers most of the Portland and Tualatin Basins, as well as the intervening Tualatin Mountains. The authors interpret the Portland Hills as “...the physiographic expression of a relatively long and narrow uplift which trends approximately $\mathrm{N} 35^{\circ} \mathrm{W}$ ". Benson and Donovan conclude that the Portland Basin could not have been produced by a simple stress system and that the Columbia River Basalt has been broken into separate blocks which have been deformed independently (Benson and Donovan, 1974). 
Beeson and others (1975), observed that the major structure of the Portland Hills is a series of en echelon folds with at least one fault and possibly another along the eastern side. They concluded that the initiation of faulting probably predates the deposition of the Columbia River Basalt Group. Beeson and others (1975) also concluded that "...the Portland area has been the site of nearly continual tectonic activity throughout the Tertiary which was associated with movement along the northwest trending "Portland Hills Fault" which may be a right lateral strike-slip fault".

Additionally, they concluded that the Portland Hills fault zone probably controlled the movement of magma for the Boring Volcanics in the area.

Similar fault traces were observed aligned with the Portland Hills trend in the Clackamas River drainage $40 \mathrm{~km}$ to the southeast by Anderson (1978). Anderson (1978), reported that northwest trending faults cut the Columbia River basalt sequence in an en echelon pattern, and both right-lateral strike-slip and dip-slip faulting had been observed.

In 1985, Beeson and others concluded that the Portland Basin is a pull-apart basin created by wrench faulting. They also concluded that the Portland Basin was an active pull-apart basin at least as early as Frenchman Springs time $(\sim 15 \mathrm{Ma})$.

Prior to the mid-1980's, most of the work to define the boundaries of the Portland Basin had focused on the western boundary. With the exception of Mundorff (1964), none of the previous workers had identified any eastern basin boundary faults. Swanson (1986), concluded that the Portland Basin was still forming after deposition of the upper Troutdale. His evidence is the apparent 130 to 165 meters of displacement within the upper Troutdale Formation between Prune Hill, Washington and Blue Lake, Oregon near the eastern boundary of the Portland Basin.

In 1987, Davis did a study of the eastern margin of the Portland Basin using gravity surveys. The detailed gravity study identified the Lacamas Creek Fault and the 
northern trace of a structure he named the Sandy River fault (Davis,1987). Davis concluded that the eastern margin of the Portland Basin began to develop after the western (Portland Hills fault) boundary. He also concluded that “...it is probable that the eastern margin developed as a response to shear activity along the Portland Hills complex".

Beeson and others (1989a) outline the influence of the Portland Hills-Clackamas structural zone on the distribution of Columbia River Basalt Group flows into the Willamette Valley. They mention that the Portland Hills-Clackamas River structural zone presently displays en echelon faults in the Clackamas River area as well as faulted anticlines and a pull-apart basin in the Portland area.

Madin (1990) mapped numerous faults within the Columbia River Basalt Group flows and within the younger sedimentary and volcanic units of the south-central and southwestern parts of the Portland Basin. Beeson and others (1989b, 1991) have also mapped numerous structures within the southwest part of the Portland Basin.

Yelin and Patton (1991) analyzed data from the 1962 Portland earthquake and analyzed approximately 30 microearthquakes that occurred in the Portland area since 1982. Their fault plane solutions are compatible with right-lateral, primary strikeslip faulting on NNW and NW trending fault planes. They also conclude that the microseismicity is associated with right lateral shear along the eastern margin of the Portland Basin, a zone they call the Frontal fault zone. Yelin and Patton (1991) concluded that the Portland Basin is a pull-apart basin formed between the Portland Hills-Clackamas River fault zone and the Frontal fault zone, and that the extension resulting from this right-stepping feature may also explain the post 5 Ma volcanism within the Portland Basin.

Portland Basin structure is dominated by a large complex set of folds and faults which comprise the western basin bounding Portland Hills-Clackamas River fault zone. 
The eastern margin consists of a series of right-stepping en echelon faults. A number of studies have identified northwest trending, right lateral strike-slip faults with associated normal, reverse, and left lateral faults (Figure 4).

Horizontal displacements along individual strike-slip faults have not been measured. Vertical displacements of approximately 150 meters have been estimated for several faults (Anderson, 1978; Swanson, 1986; Davis, 1987).

Until recently, most of the structural features associated with the Portland Basin have been identified within the Columbia River Basalt Group. Few faults that deform post-Columbia River Basalt Group units had been identified prior to 1990. The notable exceptions are Mundorff (1964) and Swanson (1986). 


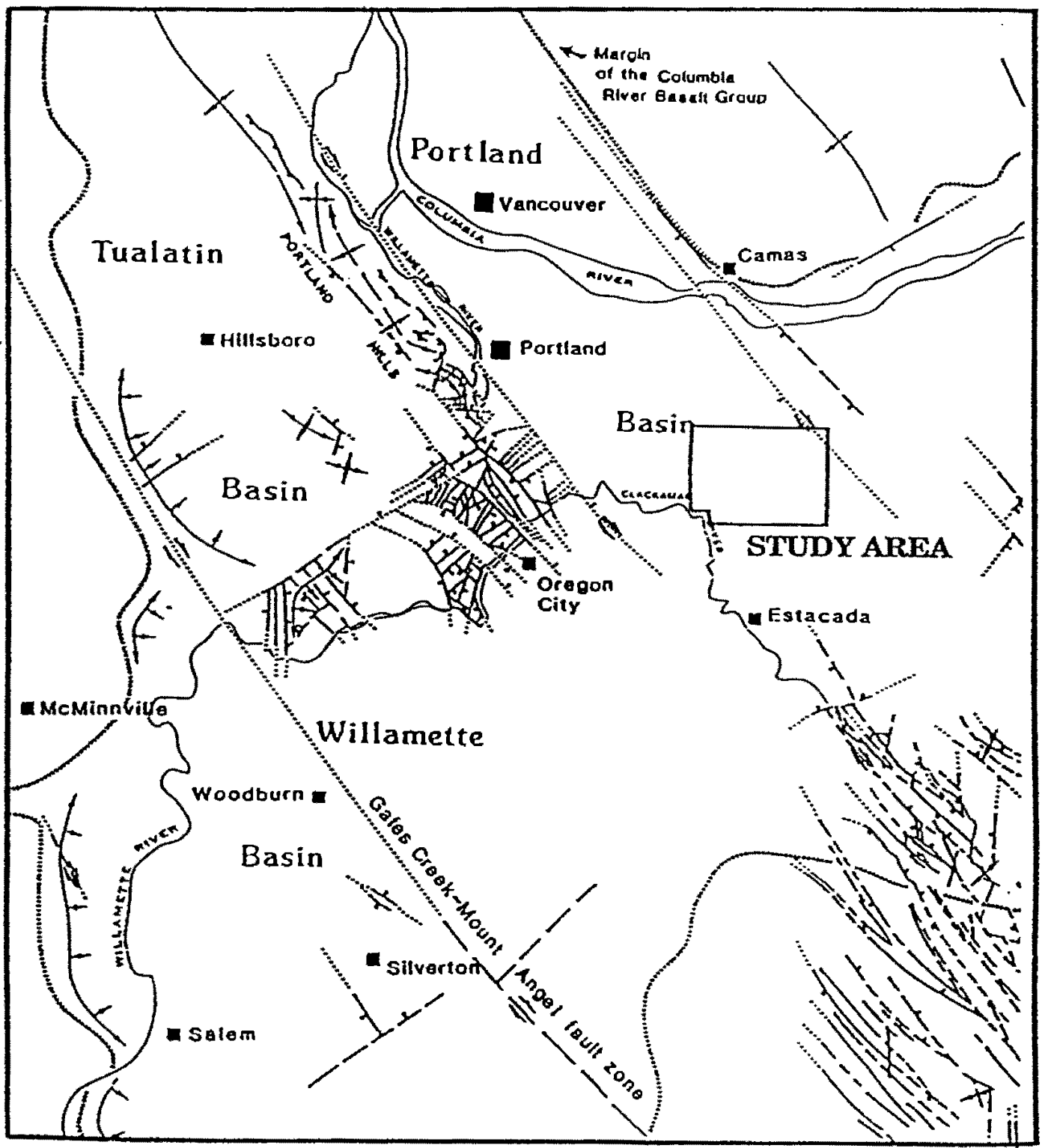

Figure 4. Tectonic map of the greater Portland area, modified from Tolan and others (1989). 


\section{AREA STRATIGRAPHY \\ COLUMBIA RIVER BASALT GROUP}

The Columbia River Basalt Group is not exposed at the surface within the study area. It is exposed in the Sandy River drainage, just outside the north-eastern study area boundary. The occurrence of Columbia River Basalt Group within the Sandy River drainage was first identified by Allen (1932). Columbia River Basalt Group units underlie the entire study area and form the basement for the sedimentary units. It has been identified within the study area in a number of water wells by Hogenson and Foxworthy (1965).

Columbia River Basalt Group units have been described and chemically analyzed in the Hood Acres Well within the study area (Marvin Beeson, personal communication, 1991). The Hood Acres Well is located in T1S/R4E, section 28DAA in the northern part of the study area. Low MgO and high MgO chemical types of Grande Ronde Basalt, as well as four flow units of the Frenchman Springs Member of Wanapum Basalt were identified (Marvin Beeson, personal communication, 1991). Wanapum Basalt flows of Ginkgo, Sand Hollow, Sentinel Gap, and Lyons Ferry were identified by Beeson.

Beeson described 167 meters thickness of Columbia River Basalt Group units in the Hood Acres Well. The bottom 15 meters of the well is low MgO Grande Ronde Basalt. The well contains 58 meters of high MgO Grande Ronde Basalt. The four units of Wanapum Basalt total 97 meters of thickness in the Hood Acres Well.

Columbia River Basalt Group units have also been described and chemically analyzed in an Oregon Department of Geology geothermal test well. The well is located within the Sandy River Canyon approximately $3 \mathrm{~km}$ northeast of the study area in 
T1S/R4E, section 11ACC (McCarthy and Anderson, 1990). Frenchman Springs Member of the Wanapum Basalt, and low MgO and high MgO Grande Ronde Basalt were identified (Marvin Beeson, personal communication, 1991). The elevation of the top of the high MgO Grande Ronde Basalt in the Sandy River Test Well is approximately 245 meters higher then in the Hood Acres Well.

The top of the Columbia River Basalt Group occurs at -424 feet elevation in the Hood Acres Well. Columbia River Basalt Group flows are thought to occur in several water wells within the study area (Hogenson and Foxworthy, 1965). Hogenson and Foxworthy (1965) report the elevation of the top of the Columbia River Basalt Group as -275 feet in T2S/R3E, section 14CAA; -43 feet in T2S/R4E, section 18DDA; and -95 feet in T2S/R4E, section 21DAA. Three additional locations were identified during this study where probable Columbia River Basalt Group material was encountered at depth in water wells. The top of the Columbia River Basalt Group is suspected to occur at elevation -486 feet in T2S/R4E, section 2CDD; -310 feet in T2S/4E, section 14CBB; and -18 feet in T2S/R4E, section $17 \mathrm{CBC}$.

\section{TROUTDALE FORMATION}

The Troutdale Formation within the study area includes clay, silt, arkosic sand, vitric sand, lithic sand, and quartzite bearing pebble and cobble conglomerates. Trimble (1963) named the the lower, predominantly fine grained part of the Troutdale Formation the Sandy River Mudstone. Trimble justified his subdivision on what he called distinct lithologic character and genesis (Trimble, 1963). The Sandy River Mudstone has been traditionally used as both a lithostratigraphic unit and a chronostratigraphic unit. Sandy River Mudstone-like deposits are interbedded throughout the Troutdale Formation within the study area. The presence of the similar material within the Troutdale Formation complicates the usage of Sandy River Mudstone 
as a chronostratigraphic unit. More appropriate chronostratigraphic unit subdivisions of the Troutdale Formation within the study area are the upper and lower member designations proposed by Tolan (1982). With the understanding that Sandy River Mudstone is the fine grained facies equivalent of the channel facies unit described by Tolan (1982) in the Bridal Veil area, the lower member of the Troutdale Formation will be used in place of Sandy River Mudstone in this discussion. This is also consistent with the usage by Mundorff (1964). A comparison of the geologic unit nomenclature used in previous studies is shown on Figure 5.

\section{Lower member of the Troutdale Formation}

A thick deposit of clay, silt, and fine sand, the lower member of the Troutdale Formation, underlies the entire study area. The unit is identified on Plates 1 and 2 as "Tt|". The upper part of the unit is exposed at the surface in the drainages of the Sandy River, Tickle Creek, Deep Creek, N. Fork Deep Creek, and Noyer Creek (Plate 1). The maximum exposed thickness of the unit within the area is approximately 55 meters where it crops out in the Sandy drainage in T2S/R4E, section 1CBA. The maximum thickness of the unit encountered in a well within the study area is approximately 215 meters in the Hood Acres Well in T1S/R4E, section 28DAA (Plate 2).

Trimble (1963) described the unit as consisting mainly of lake beds of silt or very fine sand and some conglomerate beds. Within the study area the unit is characterized by massive to thinly laminated beds of silt and fine sand (Figure 6). South of the study area in the Clackamas River drainage the unit mapped by Trimble (1963) as Sandy River Mudstone appears to be fluvial (C.D. Peterson, A.R. Niem, personal communication, 1989). Swanson (1986) analyzed Sandy River Mudstone samples using petrographic and geochemical techniques. Petrographic line count results were used to classify the samples as arkosic arenites according to the McBride classification scheme (Swanson,1986). 


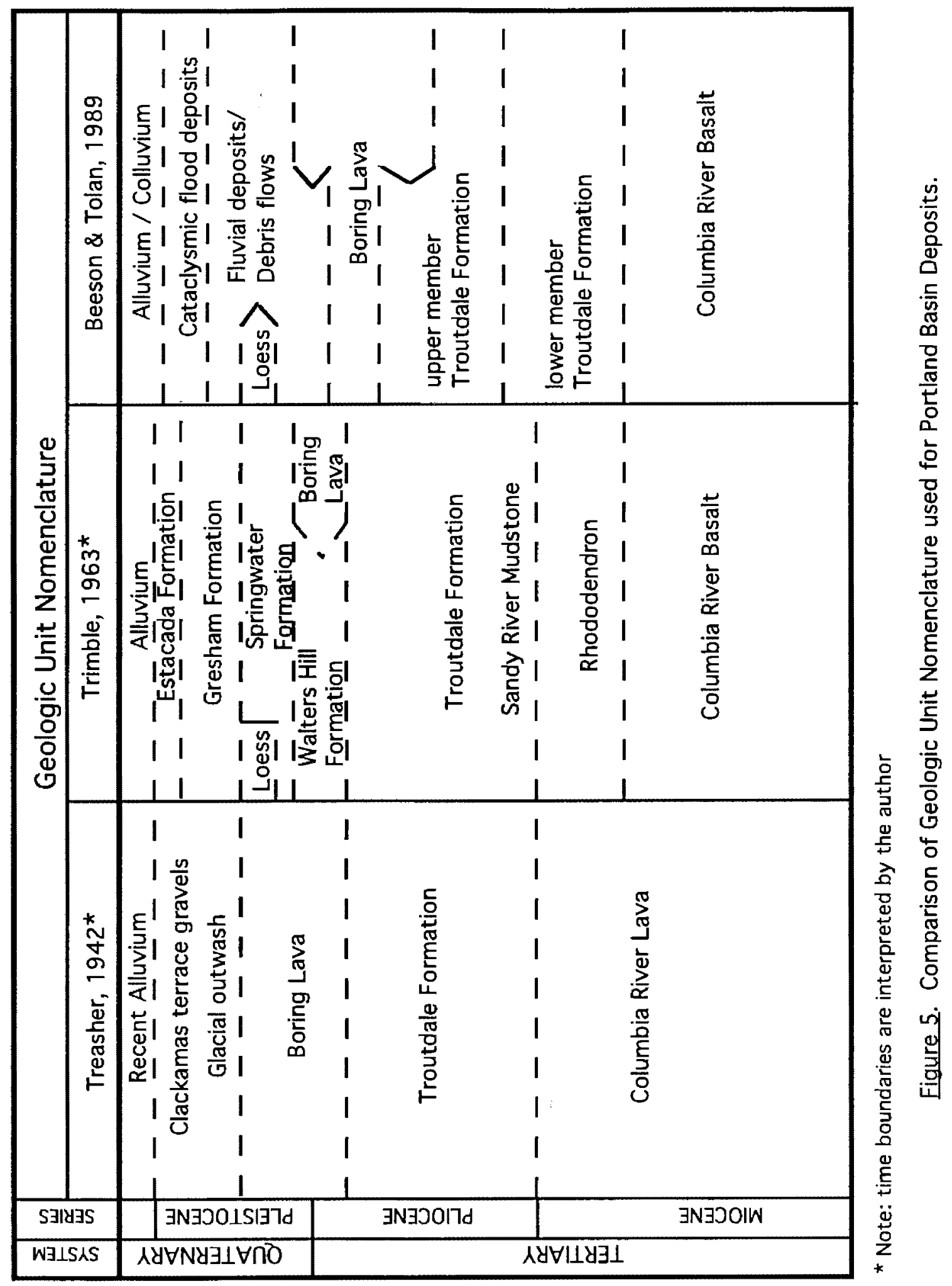



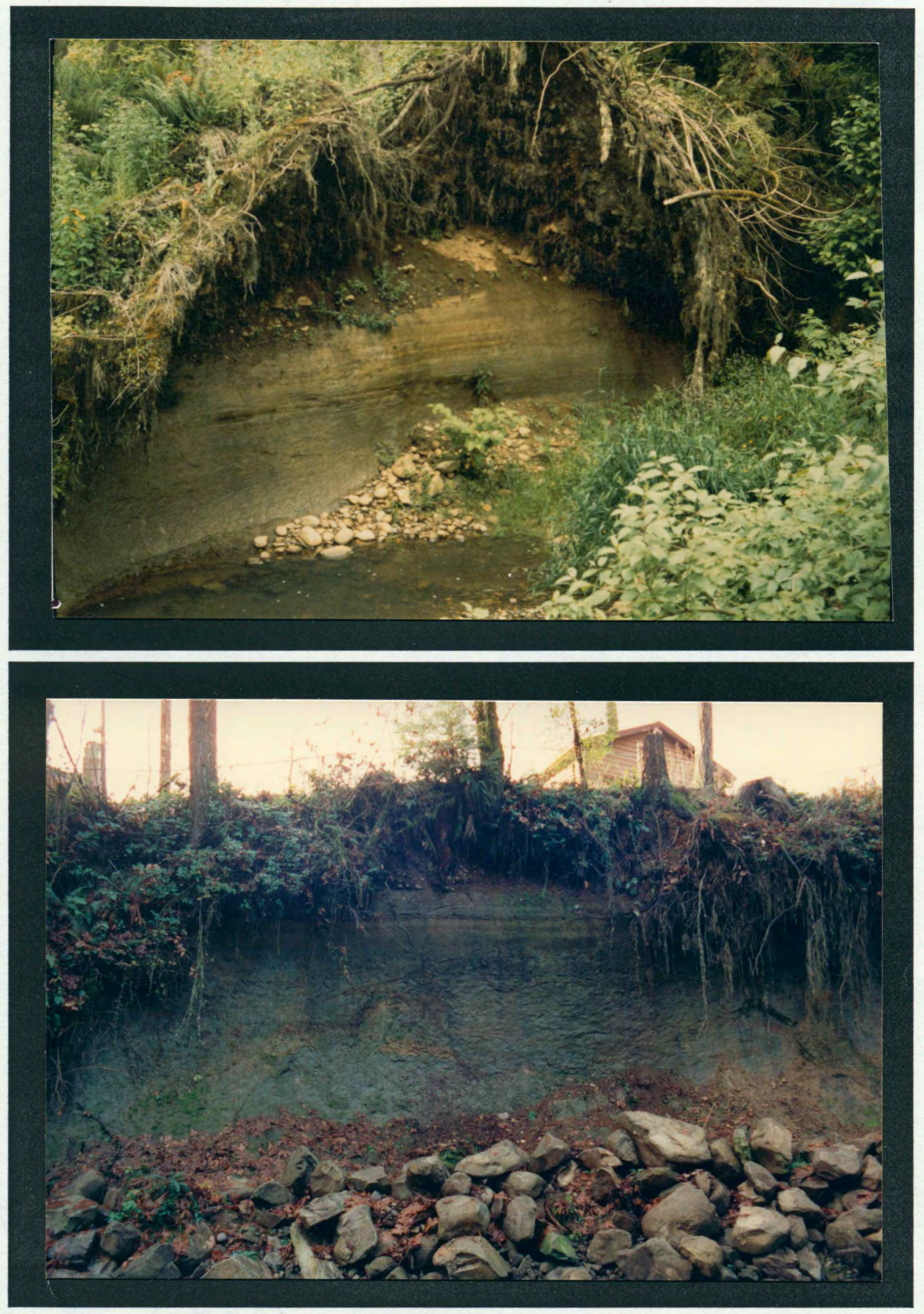

Figure 6. Massive to thinly laminated beds of the lower Troutdale member. Located in T2S/R4E, section 2OCBB and T2S/R3E, section $14 \mathrm{CBD}$. 
The lower Troutdale member unconformably overlies the Columbia River Basalt Group within the study area (Treasher, 1942). Southwest of the study area, the unit was observed overlying the Rhododendron Formation.

The lower Troutdale unit grades rapidly up into the overlying upper Troutdale sand and gravel unit at most localities where the contact has been observed within the study area. An example of the contact relationship is exposed at a site in Deep Creek near the confluence with Tickle Creek in T2S/R4E, section 18CAA (Figure 7).

Lower Troutdale siltstone was chemically analyzed from three localities during this study. The samples are chemically similar to Sandy River Mudstone samples analyzed during other studies. For example, Figure 8 shows thorium versus chromium results for Sandy River Mudstone from Swanson (1986), Wilkinson (unpublished data, 1990), and lower member siltstone from this study.

\section{Upper member of the Troutdale Formation}

The upper Troutdale is characterized by two distinct facies within the study area. One facies is a quartzite bearing pebble to cobble conglomerate with a matrix of micaceous arkosic sand. This facies is herein referred to as the Columbia River facies. The other facies is a medium to coarse grained vitric and lithic sand with occasional pebble to cobble clasts which occur predominantly towards the base of the sand unit. The upper Troutdale unit is partially exposed in all the major drainages within the study area (Plate 1).

The Columbia River facies has been previously described within the study area by Treasher (1942) and Trimble (1963). Both Treasher and Trimble mapped this unit as Troutdale Formation. The Columbia River facies is mainly exposed in the southern end of the study area. The unit is identified on Plates 1 and 2 as "Ttug". The unit is exposed in Tickle Creek, Deep Creek, N. Fork Deep Creek, and Noyer Creek ( Plate 1 ). 

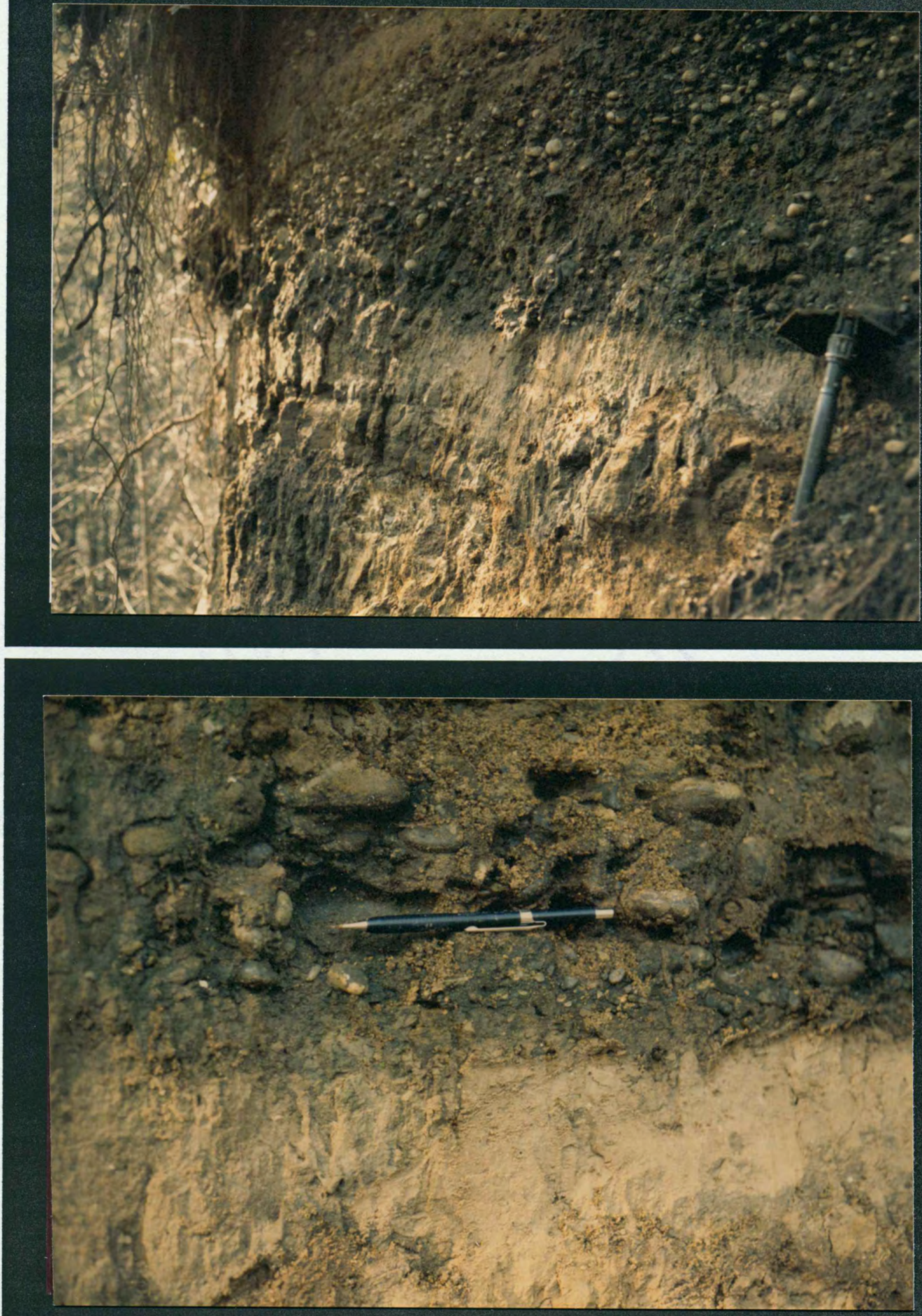

Figure 7. Contact between lower Troutdale member and Columbia River facies of upper Troutdale member. Lower photo shows close-up of the same contact. Note mechanical pencil for scale. Located in T2S/R4E, section 18CCA. 


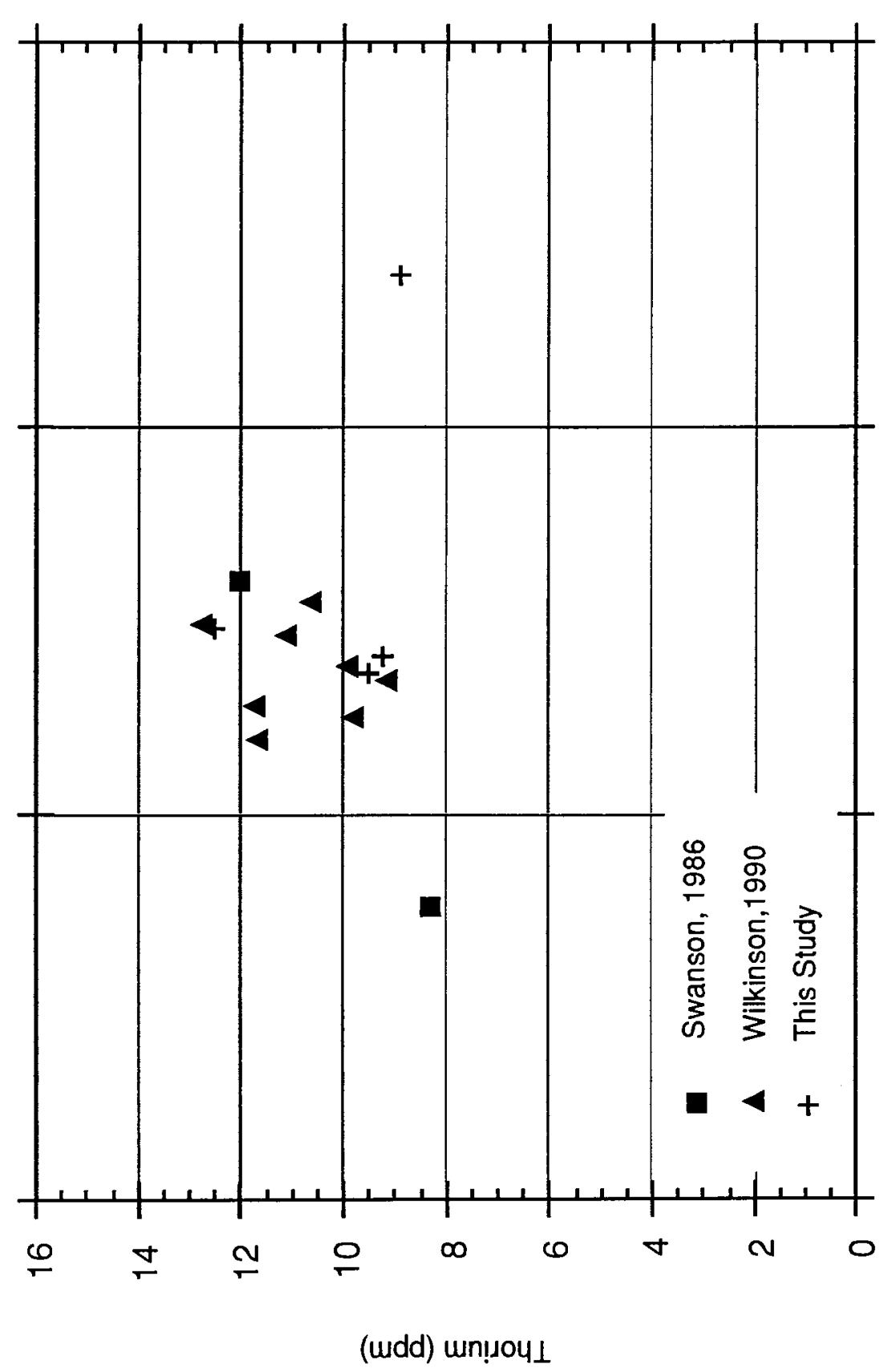

욤

فํ.

을

웅

कृ

)

离

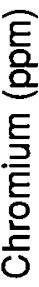

을

음

क

ำ

농

은

ह

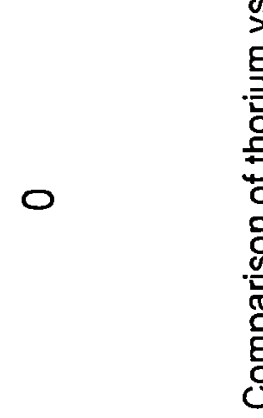

혐 
The Columbia River facies was sampled and described in five wells within the study area during this investigation (Appendix B). The maximum thickness of the unit within a sampled well is 40 meters in T2S/R4E, section 7BAA.

The quartzite conglomerate unit is commonly overlain by an arkosic sand or micaceous silt and clay layer within the study area (Figure 9). The unit is identified on Plate 1 as "Ttuc" where it is thick enough to depict on the map. The overlying layer was extensively sampled in the N. Fork Deep Creek drainage in T2S/R3E, section 1CCB. The layer is approximately 3 meters thick at that location. Major and trace element geochemical analyses were conducted on three samples from the layer in N. Fork Deep Creek. Many of the elemental values are remarkably similar to the lower Troutdale samples. An example of the similarity for scandium and chromium are shown on Figure 10. The similarity of this layer with the lower Troutdale member within the study area probably caused Trimble (1963) to erroneously map the layer as Sandy River Mudstone in Tickle Creek at T2S/R4E, sections 8 and 9 . The layer is approximately 12 meters thick at that location. The layer was also sampled and chemically analyzed at T2S/R4E, section 18ABD in Tickle Creek, and along Highway 211 at T2S/R4E, section 28ABA.

The Ttuc layer is overlain by a fine grained vitric and lithic unit at the same $\mathrm{N}$. Fork Deep Creek location mentioned above. The two fine grained units are separated by a thin approximately $20 \mathrm{~cm}$ thick organic rich paleosol (Figures 11 and 12). The fine grained vitric and lithic layer marks the base of the upper Troutdale vitric and lithic sand facies at that location. The upper Troutdale vitric and lithic sand unit is identified as "Ttus" on Plates 1 and 2.

The vitric sand facies of the upper Troutdale has been previously described within the study area by Treasher (1942) and Trimble (1963). Trimble described the unit as a vitric sandstone composed mostly of sideromelane grains (Trimble 1963). 


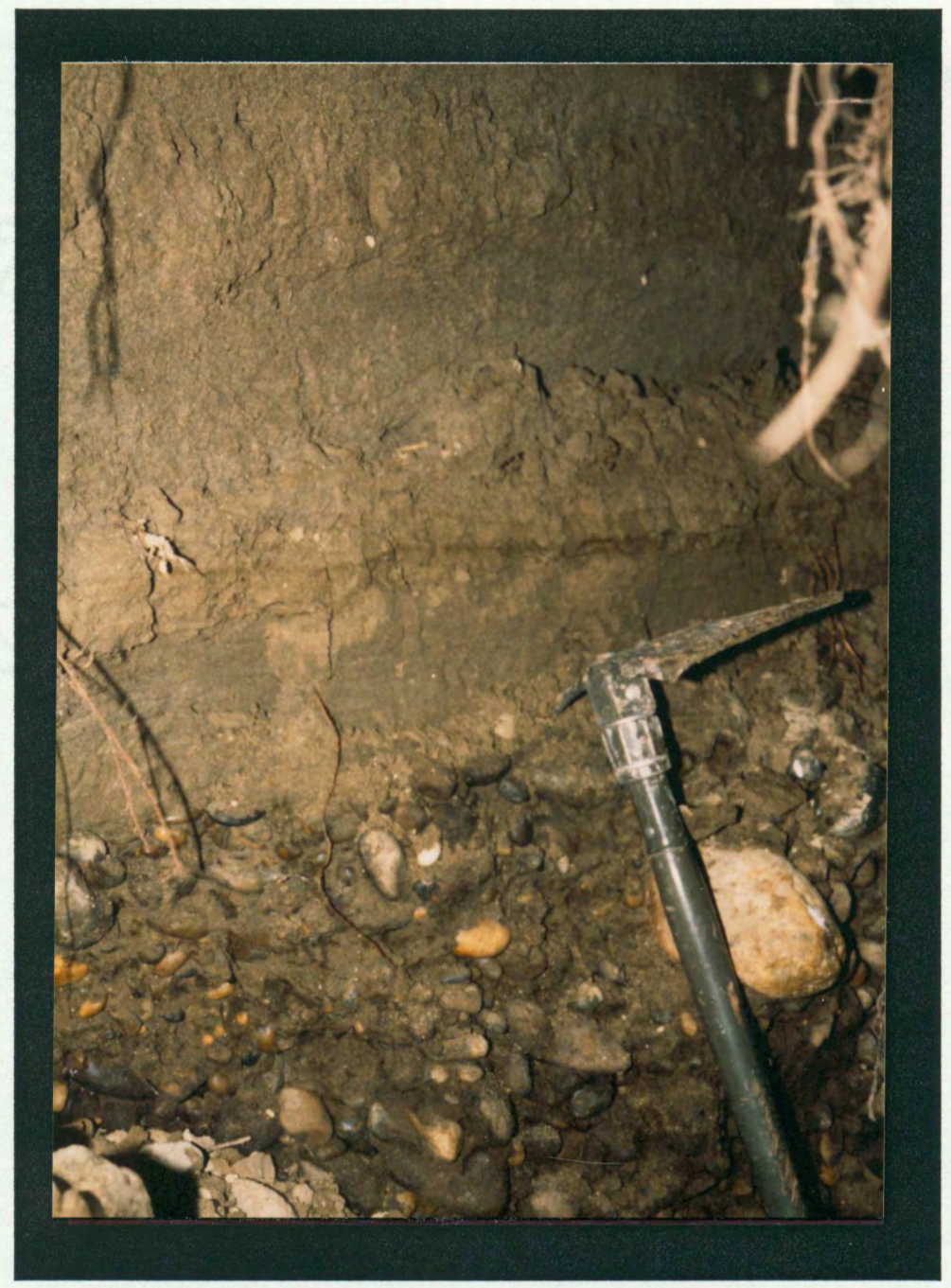

Figure 9. Fine grained lower Troutdale-like sediments overlying Columbia River facies upper Troutdale member within the N. Fork Deep Creek drainage. Located in T2S/R3E, section 1CCB. 


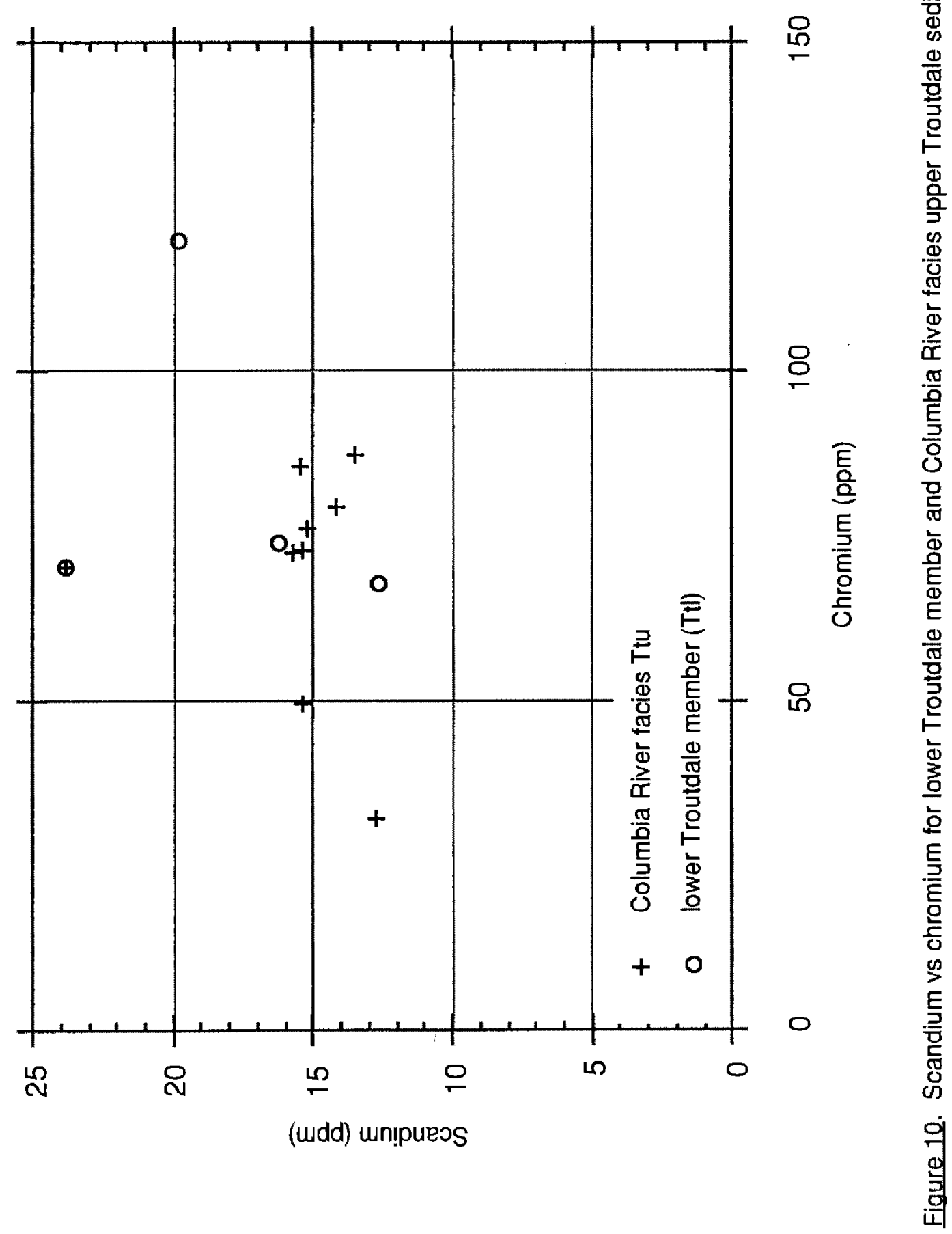




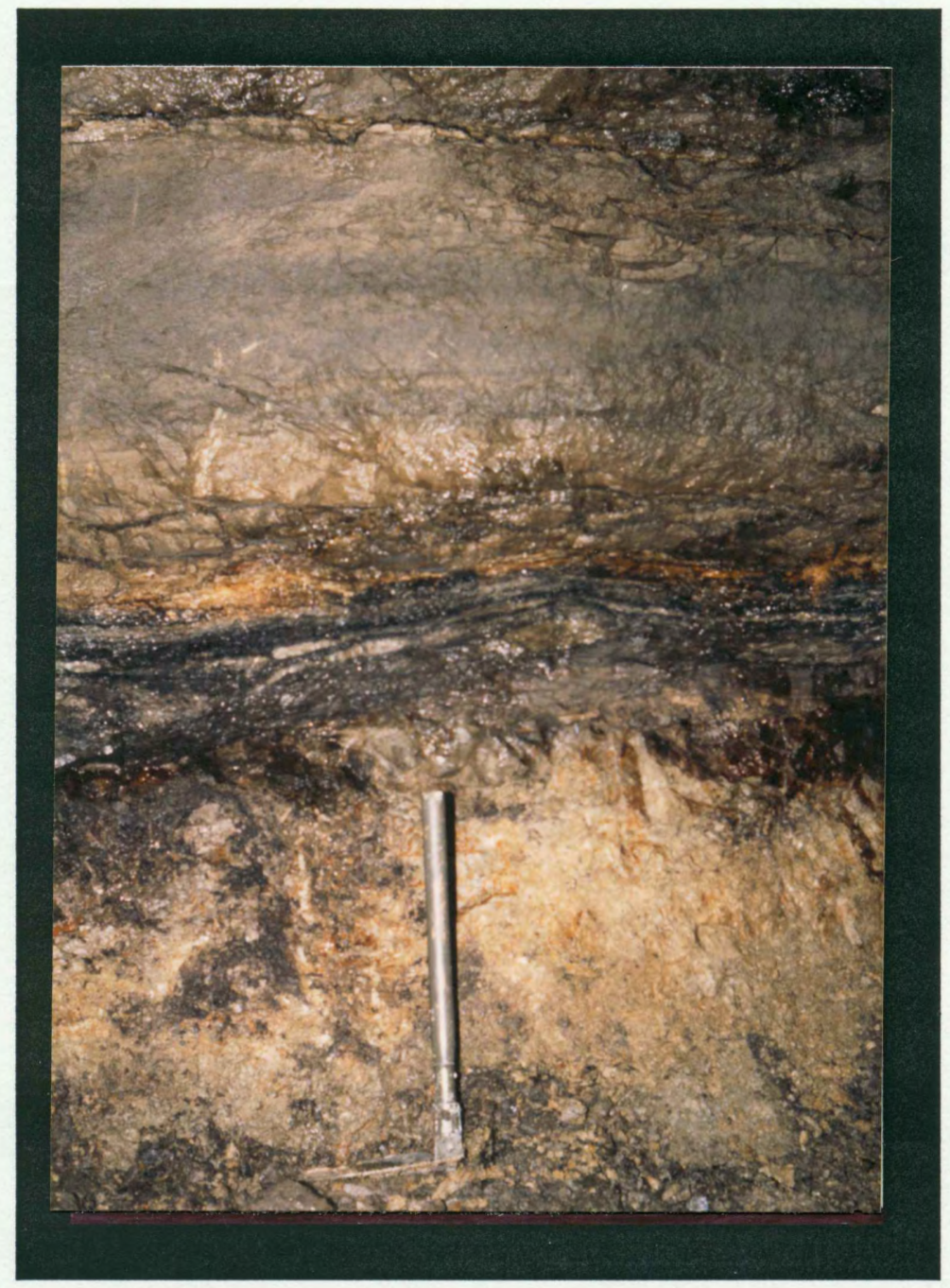

Figure 11. Fine grained upper Troutdale vitric material overlying micaceous silt and clay layer of the Columbia River facies of upper Troutdale. Located in T2S/R3E, section 1CCB. 


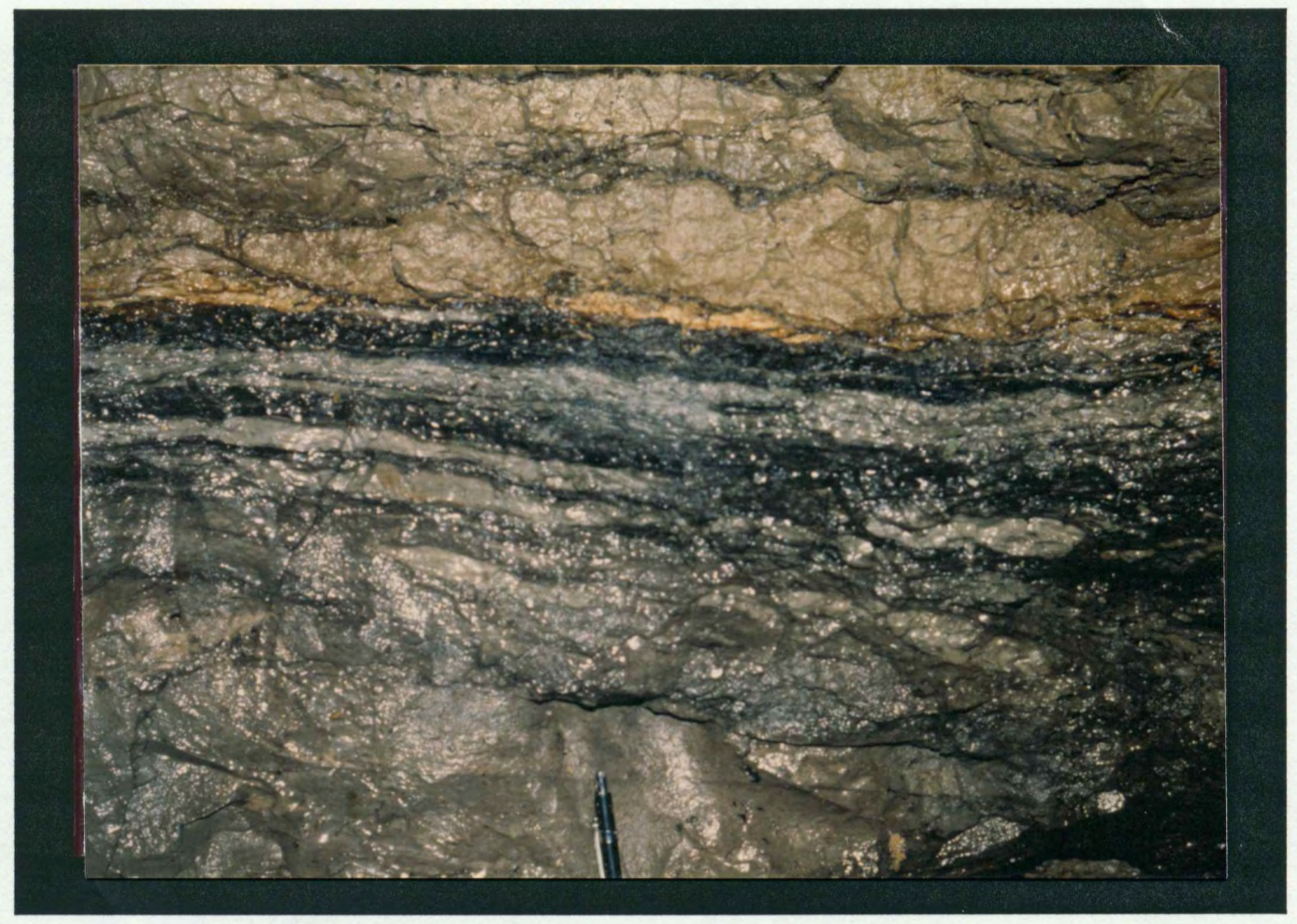

Figure 12. Close-up of the same contact shown in Figure 11. Note mechanical pencil for scale. Located in T2S/R3E, section 1CCB. 
The petrography and geochemistry of the vitric sands have been previously studied within parts of the lower Columbia River Gorge and the Portland Basin by Tolan (1982) and Swanson (1986).

Vitric sand deposits occur within the study area in three forms. The first form is a 15 to $40 \mathrm{~m}$ thick deposit of predominantly clean, reverse graded, subangular to subrounded, medium to coarse grained vitric sand or vitric and lithic sand, with occasional subangular to angular volcanic pebble to boulder clasts (Figure 13, Appendix B). The exposures are commonly yellow brown to black in color due to the partial to complete palagonitization of the vitric grains. Grains examined from well cutting samples are mostly slightly to moderately palagonitized. Occasionally the grains are completely altered. Palagonite appears to be the primary cement for the sands. A similar observation was made of the vitric sand deposits in the lower Columbia Gorge by Tolan (1982).

The second form of the vitric sand deposit is a reverse graded medium to coarse grained sand with matrix to clast supported pebbles and cobbles forming the lower part of the unit. An example of this form is exposed near the confluence of N. Fork Deep Creek and Deep Creek in T2S/R3E, section 14CAB (Figure 14). The clasts are predominantly quartzite and basalt, similar to the Columbia River facies clasts.

The third type of occurrence of the vitric sands is as layers within quartzite bearing pebble and cobble conglomerate and arkosic sand layers. This relationship was only occasionally recognized in the field, but was readily apparent during microscopic inspection of drill cutting samples and from geochemical analyses. This depositional form is included as "Ttug" on Plates 1 and 2.

The upper Troutdale vitric and lithic material also locally occurs as silt and clay layers overlying the coarser sand material. The overlying fine grained layers appear to be very similar to the fine grained layer at the base of the unit identified in N. Fork Deep 


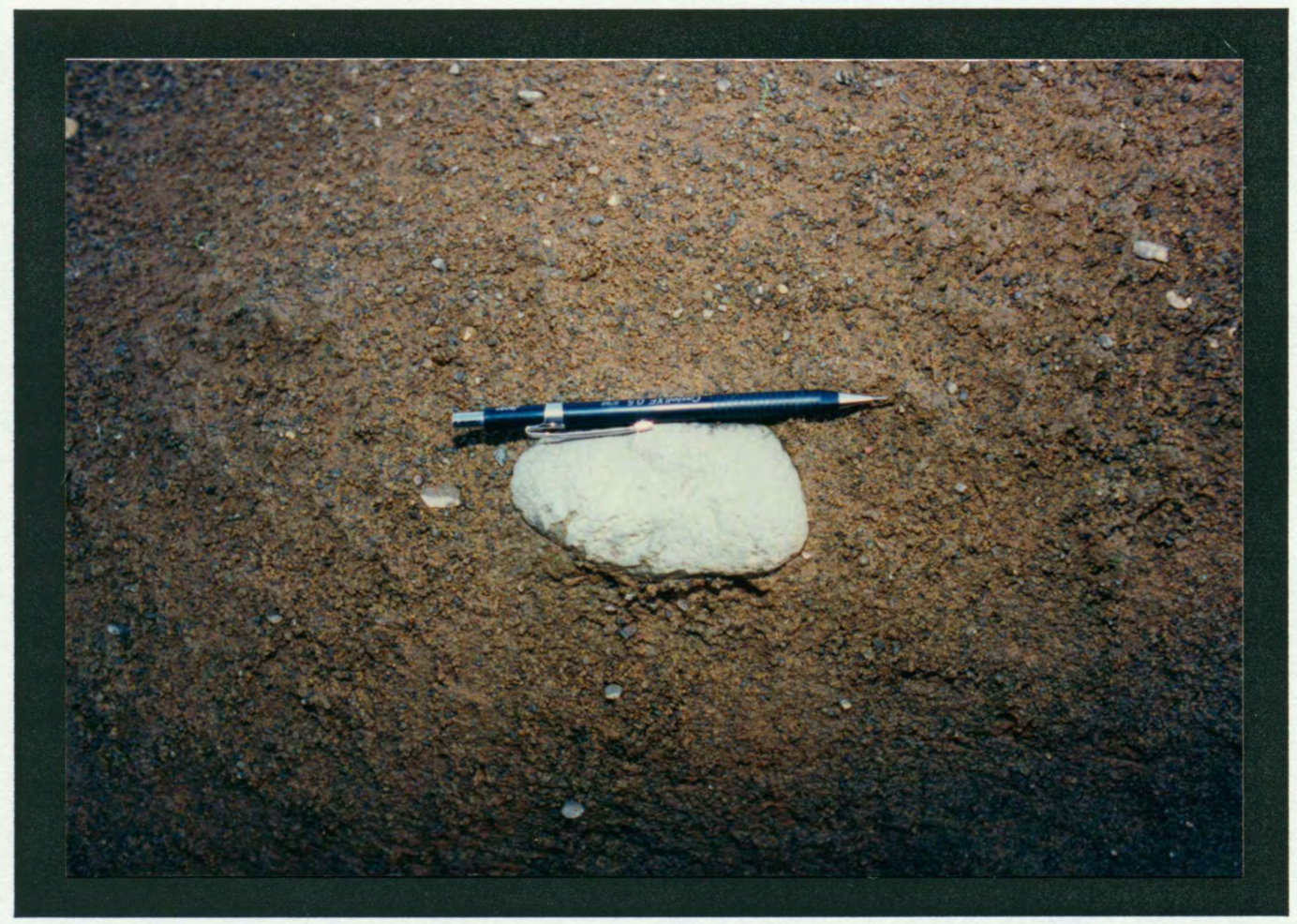

Figure 13. An $8 \mathrm{~cm}$ basalt clast within coarse grained vitric and lithic sand unit of the upper Troutdale member. Located in T2S/R3E, section $14 \mathrm{CAB}$. 

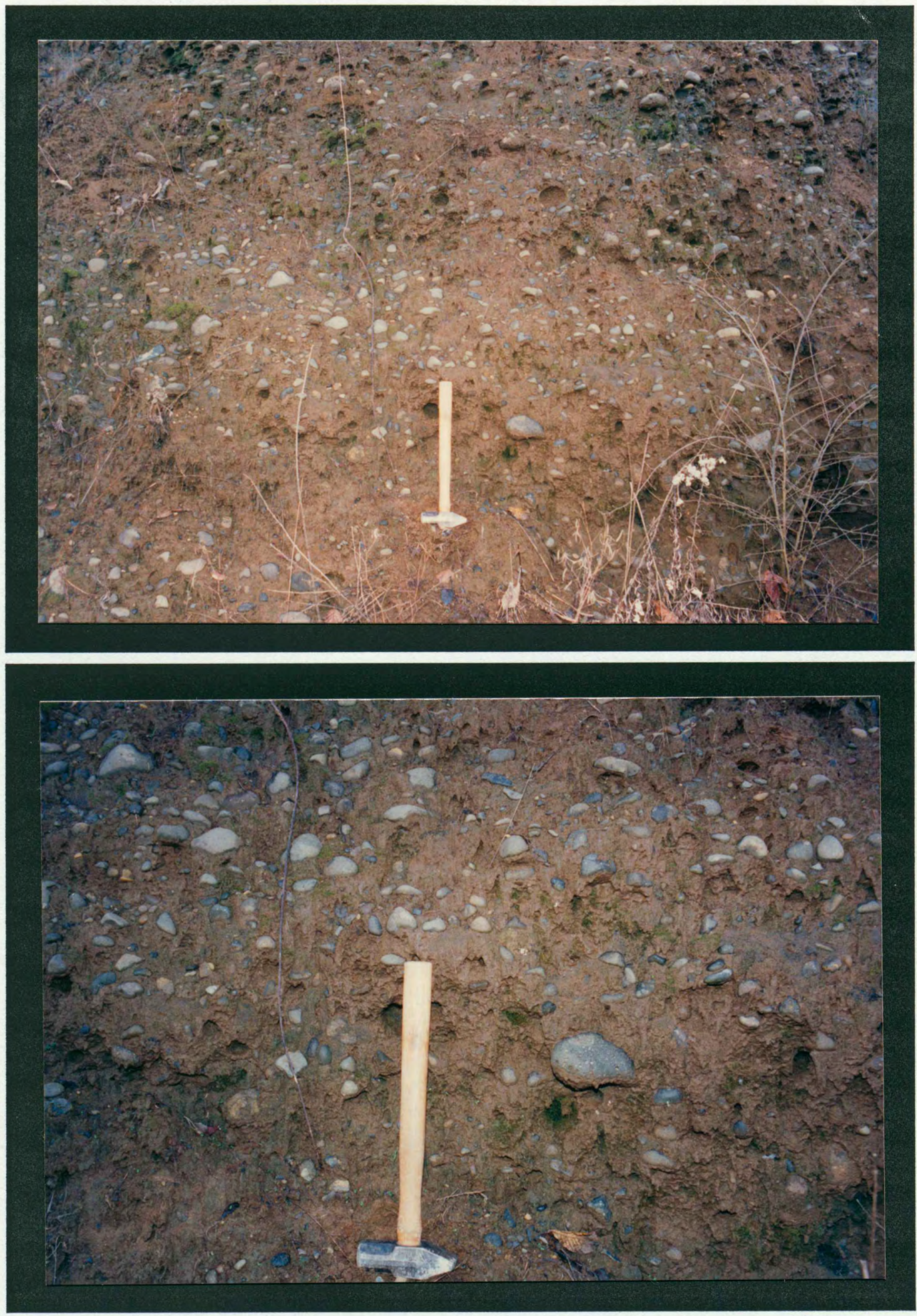

Figure 14. Matrix supported basalt and quartzite clasts within vitric and lithic unit of the upper Troutdale member. Lower photo shows close-up of the same outcrop. Located in T2S/R3E, section 14CAB. 
Creek. Three locations were sampled and chemically analyzed during this study. The samples from the silt and clay layers overlying the vitric sand material were found to be chemically similar to the vitric sand samples.

\section{BORING LAVA}

Boring Lava is poorly exposed within the study area. Trimble (1963) and Hogenson and Foxworthy (1964) mapped Boring Lava as isolated outcrops along the Sandy River Canyon and the main constituent of the Boring Hills. Burch (thesis manuscript, 1980) collected and chemically analyzed one sample within this study area. The unit is identified as "QTV" on Plates 1 and 2.

Only isolated weathered exposures of Boring Lavas were found in the two large Boring Hills located within the study area. Mostly, Troutdale-like sediments and volcanic breccia were identified in the hills northwest of Boring, Oregon.

Relatively good exposures of Boring Lava material were identified in an unnamed drainage in T1S/R3E, section 25CAB. The creek drains the west flank of a conical shaped hill north-northwest of Boring. The hill is interpreted as a Boring Lava vent, based on several water well drilling records. A well constructed at the peak of the hill encountered over 150 meters of material described by the driller as lava, basalt, and cinders. Exposures at the base of the hill consist of vesicular blocks ( $<1$ meter) of Boring Lava in a matrix of mudflow debris. The Boring Lava material is fine grained, gray, diktytaxitic basalt with some olivine phenocrysts. A driller's description from a nearby well indicates that the exposed material may be underlain by a lava flow.

"Basalt" flows have been noted on several water well reports within the study area. Most notable is a basalt flow reported from elevation 251 to 220 feet in the Hood Acres Well. Stratigraphically, the flow directly overlies the lower member of the Troutdale Formation. Another flow was sampled from a well in T1S/R4E, section 
34AAD. This flow occurs between elevation 530 and 460 feet, and directly overlies upper Troutdale vitric sand (Appendix B). The flow was analyzed for major oxides and some trace elements. The chemistry of the flow is similar to most of the vitric and lithic sands analyzed for this study.

Boring Lava appears to be intercalated with the upper member of the Troutdale Formation within the study area. Boring Lava intercalated with Troutdale Formation vitric sand has also been recognized in the lower Columbia Gorge by Williams in 1916, and Lowry and Baldwin in 1952 (Tolan, 1982).

\section{POST-TROUTDALE SEDIMENTS AND DEBRIS FLOWS}

Distinct post-Troutdale deposits were recognized within the study area by Allen (1932). Allen proposed the name Deep Canyon Formation for a deposit of "rotten" conglomerate occurring in the vicinity of Deep Creek (Allen, 1932). These deposits were later mapped as Springwater Formation (Trimble, 1963). The Springwater Formation has been described as a fluvial cobble gravel and bouldery cobble gravel with interstratified mudflow deposits locally forming a large part of the unit (Trimble, 1963).

The post-Troutdale deposits occur throughout the study area. The unit is identified as "QTs" on Plates 1 and 2. The unit is generally thickest in the northeast part of the study area and thinnest in the southwest part of the area. The unit is present in all the wells sampled and analyzed during this study (Appendix B). The thickest occurrence of the unit analyzed during this study is in T1S/R4E, section 27ADC. The deposit is 67 meters thick at that location. The post-Troutdale sediments are generally distinguished from the upper Troutdale material by the abundance of coarse grained volcanic clasts, degree of weathering, and lack of sorting (Figure 15). The postTroutdale sediments are locally separated from the underlying upper Troutdale vitric 

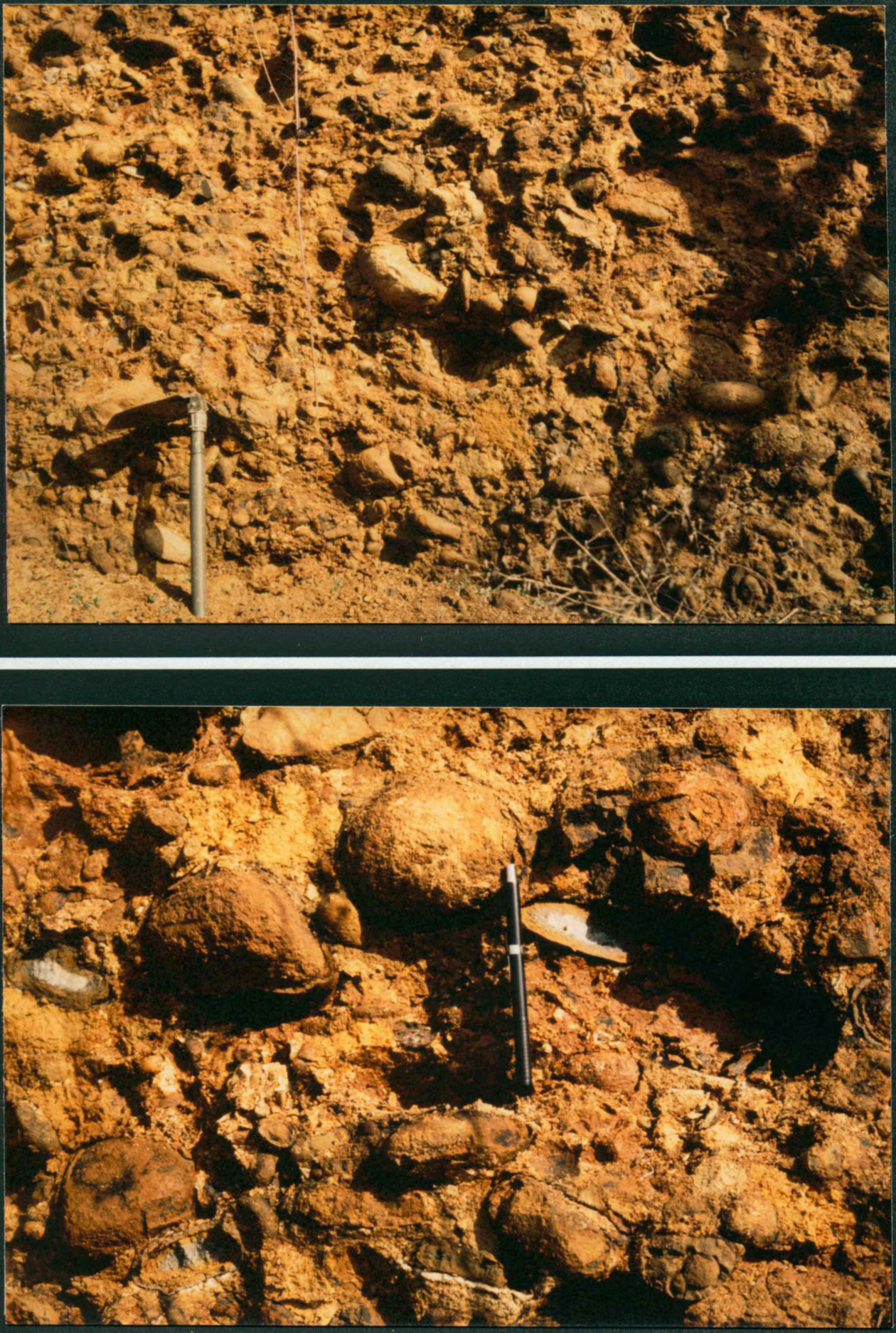

Figure 15. Weathered, unsorted, clast supported sediments typical of the post-Troutdale unit. Lower photo shows close-up of the same outcrop. Located in T2S/R4E, section 18AAC. 
and lithic sand unit by a fine grained, predominantly upper Troutdale-like silt and clay layer.

Several volcanic deposits were observed within the post- Troutdale deposits in the northern part of the study area. An approximately 6 meters thick lava flow material was identified within the unit in T2S/R4E, section 8BAA. The identification was made on the basis of a well drillers report and drill cutting samples. The flow occurs in the uppermost part of the unit (Appendix B). The flow was chemically analyzed for major and trace elements (Appendix A). The results of the analyses show the flow to be chemically similar to Cascade Range andesite flows. A large approximately 3 to 4 meter wide block within a debris flow was also sampled and analyzed from the study area. This flow is exposed in a roadcut in the Sandy River Canyon in T1S/R4E, section 36ABB. The debris flow appears to be an intracanyon deposit and thus does not relate stratigraphically to the previously described lava flow. The microscopic appearance of the two samples is quite similar. The major and trace element chemistry are remarkably similar between the flow samples (Appendix A). The debris flow exposed in the Sandy Canyon occurs as large blocks of rock surrounded by flow breccia and mudflow breccia. Similar appearing mudflow breccia and flow breccia are exposed elsewhere in the Sandy River Canyon and near Boring, Oregon. Most of the mudflow deposits are described by Trimble (1963).

A previously unmapped mudflow deposit was identified during this study in T2S/R3E, section 1ACD (Figure 16). The matrix and one clast were sampled and chemically analyzed as part of this study. The chemistry of the matrix material is also very similar to the andesite debris flow samples (Appendix A).

Weathered material similar in appearance to the weathered parts of the flow breccia identified in the Sandy River Canyon occurs in the vicinity of the Boring Hills. The weathered breccia was sampled and chemically analyzed from a site on the lower 

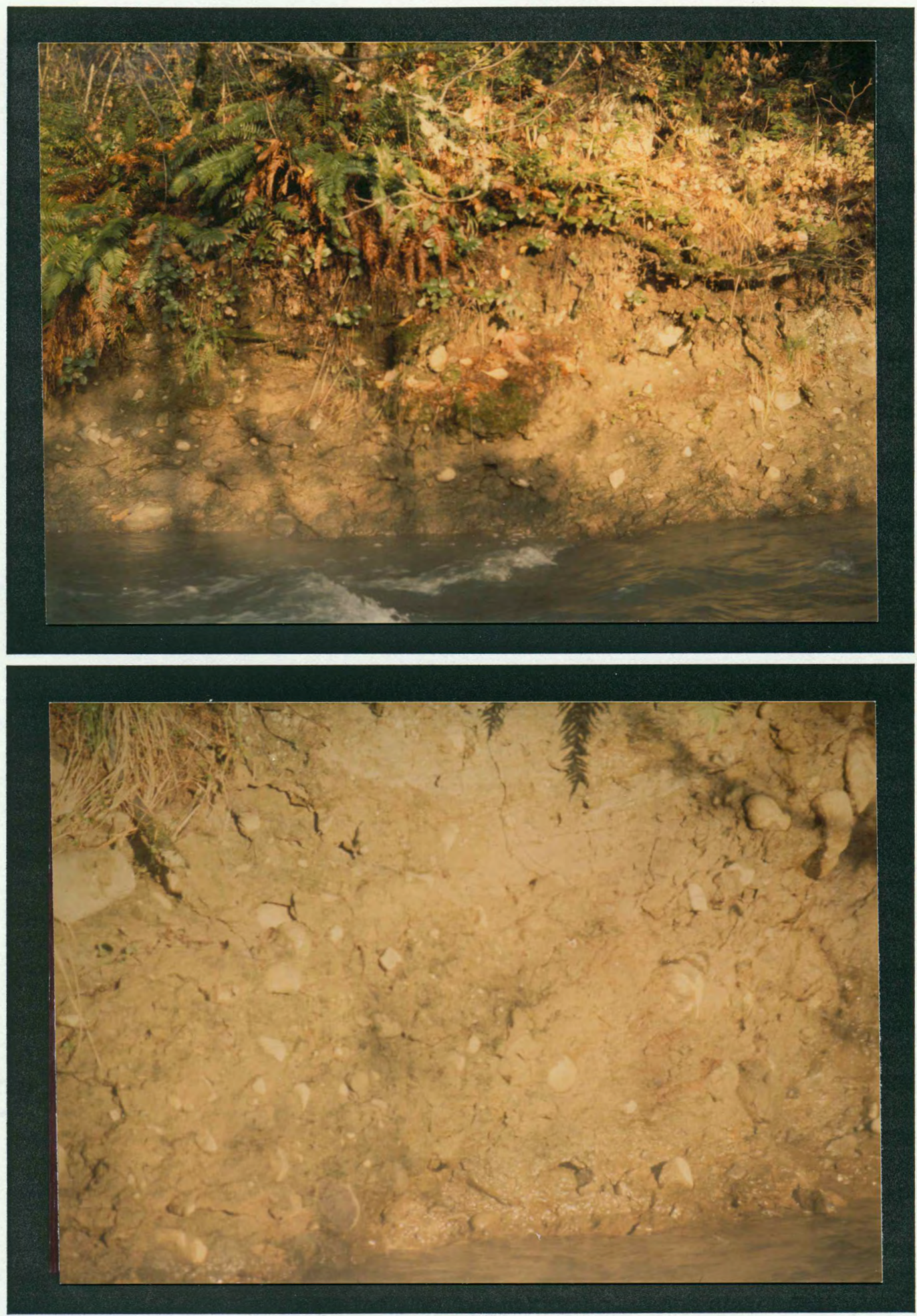

Figure 16. Mudflow deposit within the post-Troutdale unit. Lower photo shows close-up of the same contact. Located in T2S/R3E, section 1ACD. 
flank of one of the Boring Hills in T1S/R3E, section 26ABC. The chemical results are inconclusive due to the weathering of the sample (Appendix A). Some of the elemental abundances are similar to Cascade Range andesites. Other chemical plots indicate that the sample is similar to basaltic andesite type Boring Lava. Trimble mapped this unit as Walters Hill Formation.

Previous sampling and chemical analysis at two sites in the Boring Hills within the study area yielded chemical results more similar to the andesite debris flows and mudflow deposits then that of Boring Lava (Burch, thesis manuscript, 1980 and Beeson, unpublished data, 1986). It is presumed that Burch mistakenly sampled debris flow clasts instead of Boring Lava at those sites.

\section{CHEMICAL ANALYSES OF TROUTDALE AND POST-TROUTDALE UNITS}

\section{Introduction}

Forty-four samples were originally selected from the study area for chemical analysis. Instrumental neutron activation analysis was used to determine the elemental abundances within the samples. Twenty of the forty-four samples were selected for additional analysis using an x-ray fluorescence technique. The sedimentary samples used for chemical analyses were silt to clay sized samples. A relatively uniform fine grained sample was used to minimize the possible effects of grain size distribution on the analyses. An additional six samples were subsequently analyzed with the $x$-ray fluorescence technique. Additional analyses were obtained to provide more chemical data for the vitric and lithic sands within the study area, and an analysis of a lava flow intercalated with the vitric and lithic upper Troutdale part of the section. The clastic samples were medium sands to fine gravels. 


\section{Chemical Groups}

Graphs of the chemical data indicate that most samples cluster in one of four groups. The best groupings were obtained by using a combination of trace elements and major oxides.

The constituents that best distinguish the various samples are thorium, lanthanum, scandium, chromium, magnesium oxide, titanium oxide, and silica. Variance diagrams of thorium versus silica, scandium versus silica, and thorium versus scandium illustrate the four distinct groupings (Figures 17, 18, and 19). The numbers on the graphs correspond with the sample numbers (Plate 1, Appendix A and B). Note that the same samples tend to group together in each of the graphs.

Group 1 samples are from the lower Troutdale member, and from the Columbia River facies of the upper Troutdale member. Group 1 samples have silica values ranging from 67 to 73 percent; thorium values ranging from 9 to $15 \mathrm{ppm}$; and scandium values between 13 and $17 \mathrm{ppm}$.

Group 2 samples are from the vitric and lithic unit of the upper Troutdale member. Group 2 samples have silica values from 54 to 58 percent; thorium values ranging from 3.5 to $5 \mathrm{ppm}$; and scandium values between 19 and $24 \mathrm{ppm}$.

Group 3 samples are also from the vitric and lithic unit of the upper Troutdale member. Group 3 samples have silica values ranging from 49 to 53 percent; thorium values between 0.5 and $2.1 \mathrm{ppm}$; and scandium values between 31 and $37 \mathrm{ppm}$. Group 3 also includes a sample from a lava flow overlying the vitric and lithic unit (Sample 45).

Group 4 samples are from debris flows within the post-Troutdale deposits. Group 4 samples have silica values ranging from 57 to 63 percent; thorium values between 1.5 and $3.5 \mathrm{ppm}$; and scandium values ranging from 11 to $14 \mathrm{ppm}$. 


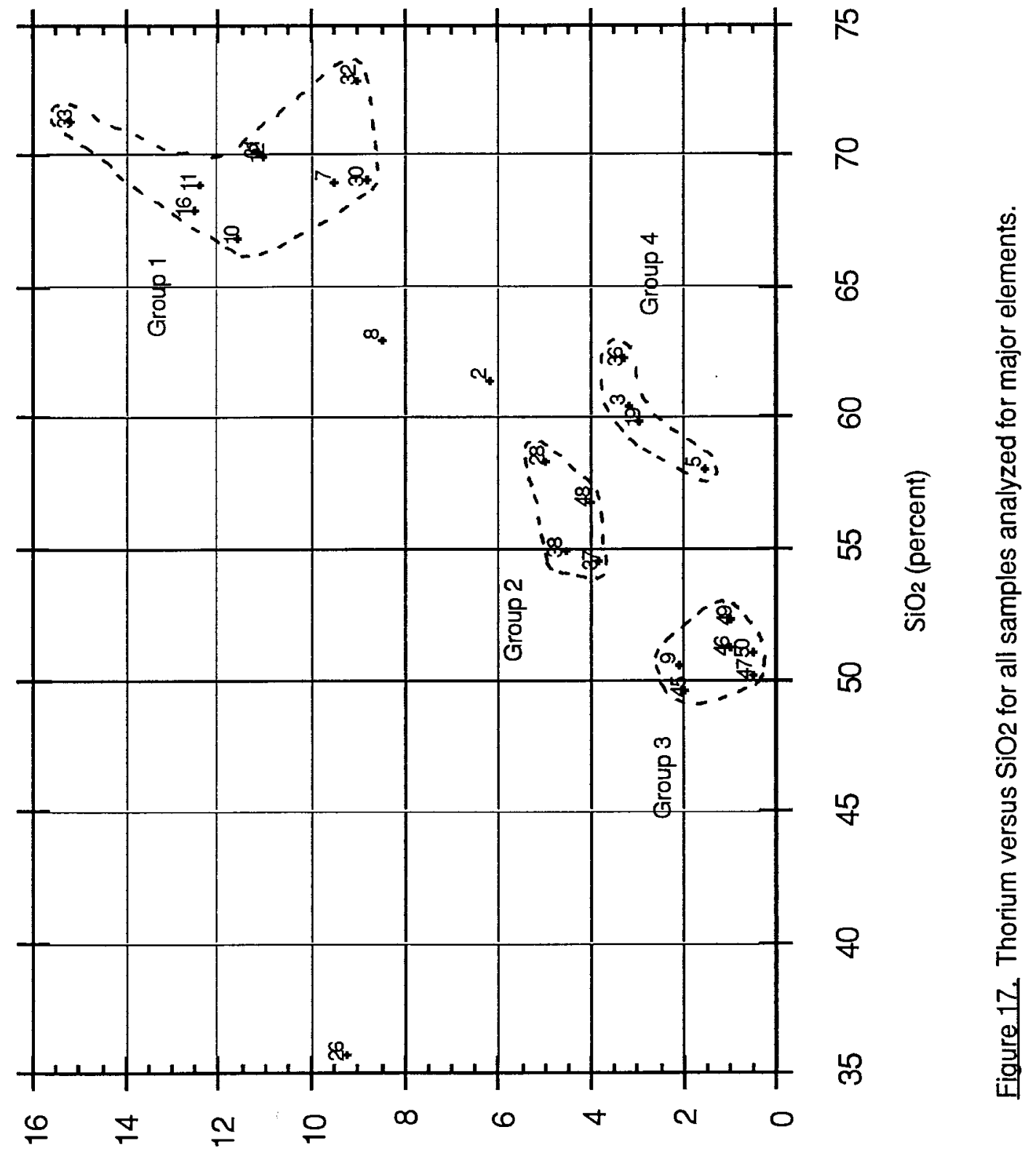

(udd) wn!ı $1 \perp$ 


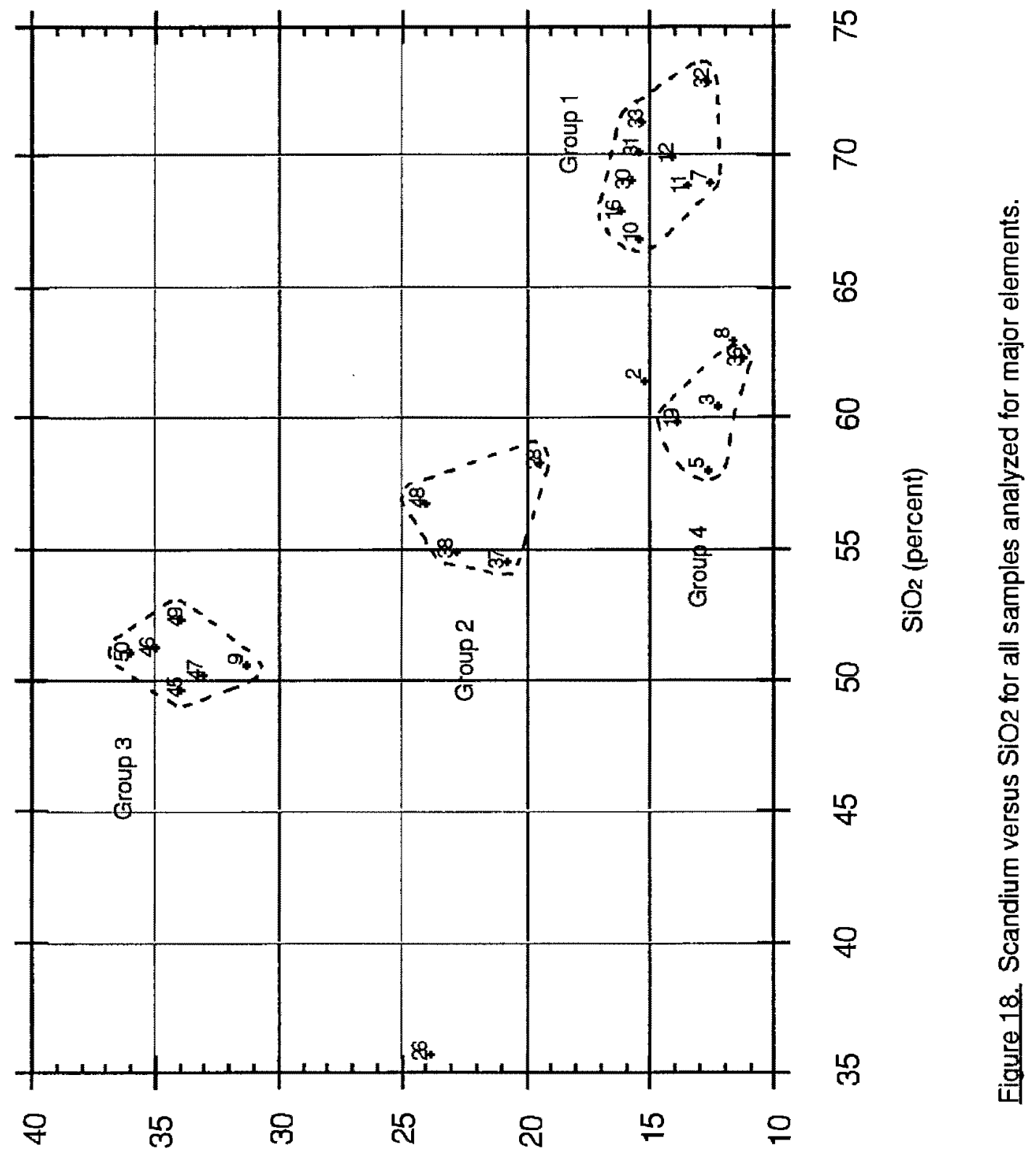

(udd) un!pueos 


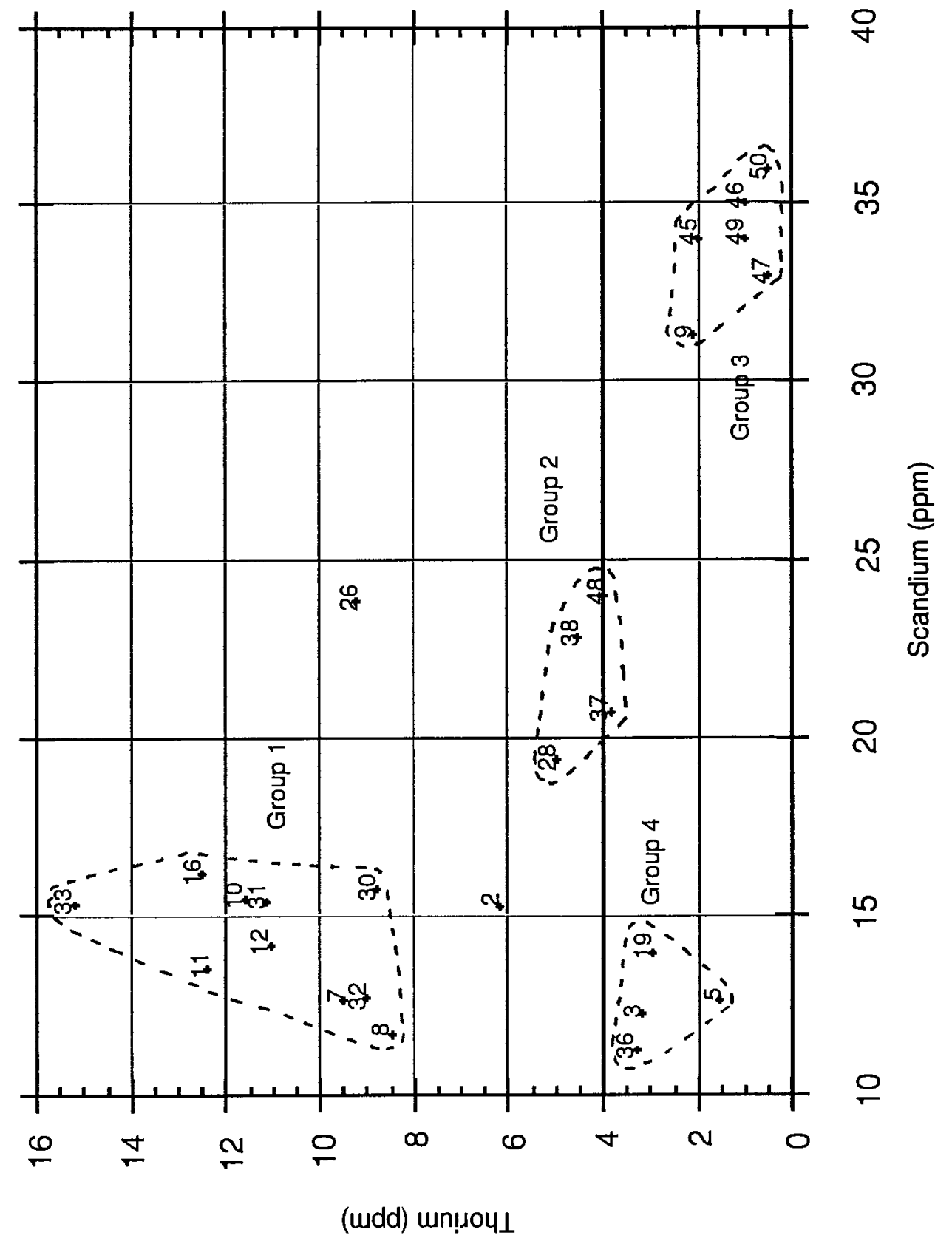

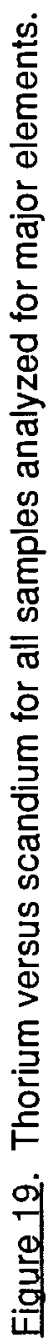




\section{POSSIBLE SOURCE AREAS FOR THE SEDIMENTARY UNITS}

Two distinct sources for the stratigraphic units within the study area are apparent from an analysis of the sediment lithology and the chemical data. The presence of micaceous silt and sand, together with the abundance of quartzite and other exotic clasts within some units indicate a source area that includes plutonic and metamorphic rocks. The Columbia Basin has been previously recognized as the probable area for much of the micaceous and quartzite bearing deposits (Trimble, 1963; Mundorff, 1964).

Basaltic vitric and lithic sand, as well as the abundance of high alumina basalt and andesite volcanic clasts in many of the upper Troutdale and post-Troutdale deposits indicate a Cascade Range origin for those deposits. The Cascade Range has long been recognized as the likely source area for the vitric and lithic sand units and postTroutdale deposits (Allen, 1932; Trimble, 1963).

Chemical analysis of samples from the study area support the lithologic based conclusion that two very different source areas contributed to the sedimentary deposits. The chemical characteristics of the two source areas are very distinct. Figure 20 shows a comparison of the range of values within the stratigraphic units for chromium, thorium, scandium, silica, and titanium oxide.

The Columbia River Basin derived sediments are easily distinguished from the Cascade Range derived material by the higher thorium, lanthanum, and silica content (Figures 17 and 20, Appendix A). Group 1 on Figure 17 contains Columbia River Basin derived sediment samples.

The Cascade Range derived material appears to represent three distinct chemical groups. Sediments derived from the Cascade Range exhibit chemistry similar to basalt, basaltic andesite, and andesite rock types. A comparison of chemistry from the vitric- 


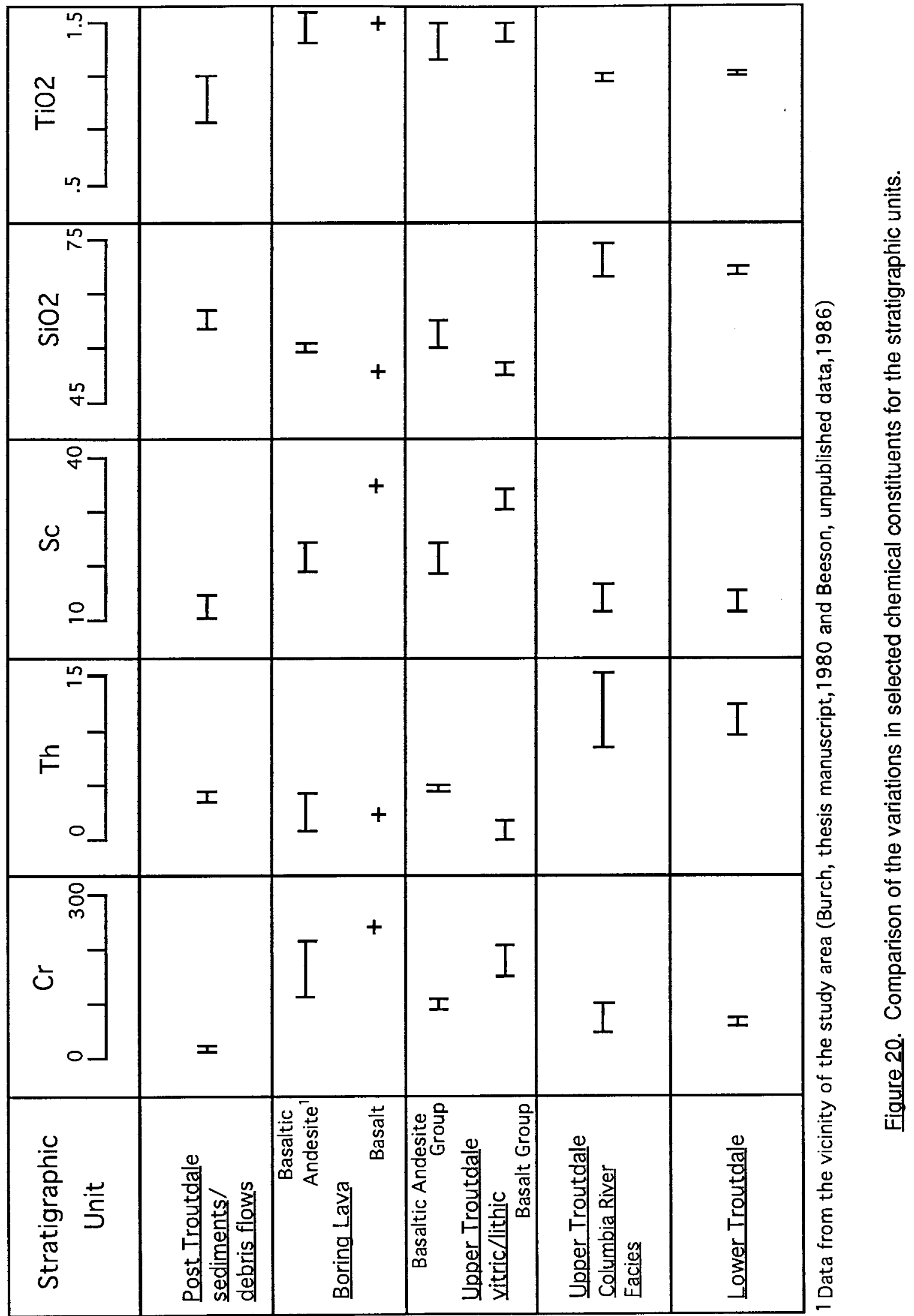


lithic upper Troutdale material and Cascades basalt and basaltic andesite material illustrate the similarities (Figure 21). The variance diagram of scandium versus silica also illustrates that the vitric-lithic upper Troutdale sediments plot in two distinct fields. One field exhibits higher scandium ( 32 to $42 \mathrm{ppm}$ ) and generally lower silica (47 to 53 percent). Most of the samples in the higher scandium, lower silica field are basalt composition. The samples from this study that are within the basalt group are those graphed as Group 3 on Figure 18. The other field containing upper Troutdale sediments is lower in scandium (19 to $28 \mathrm{ppm}$ ) and generally higher in silica (51 to 58 percent). Most of the samples in this field exhibit basaltic andesite composition. The basaltic andesite type sediments from this study are those shown as Group 2 on Figure 18.

The basalt composition group in Figure 21 also includes several chemically similar samples from Rhododendron Ridge (Hammond, 1988) and one sample from the Mt. Hood area (Gannett, 1982). The basaltic andesite composition field also contains several chemically similar samples of Boring Lava from the vicinity of the study area and within the Portland Basin (Burch, thesis manuscript, 1980) and (Beeson, unpublished data, 1986); one sample from the Mt. Hood area (Gannett, 1982) and one sample from Rhododendron Ridge (Hammond, 1988).

The post-Troutdale sediments and debris flow unit exhibit two distinct chemical types. Only one of the chemical types is displayed on Figure 21 . The chemical type not shown is indistinguishable from the basaltic andesite type vitric and lithic sediments of the upper Troutdale Formation. This chemical type is found in fine grained sediments interlayered within the coarse grained sand and pebble to cobble conglomerates. The other chemical type is found in the interlayered debris flow units. The chemistry of the volcaniclastic sediments are typically lower in chromium and scandium, and higher in 


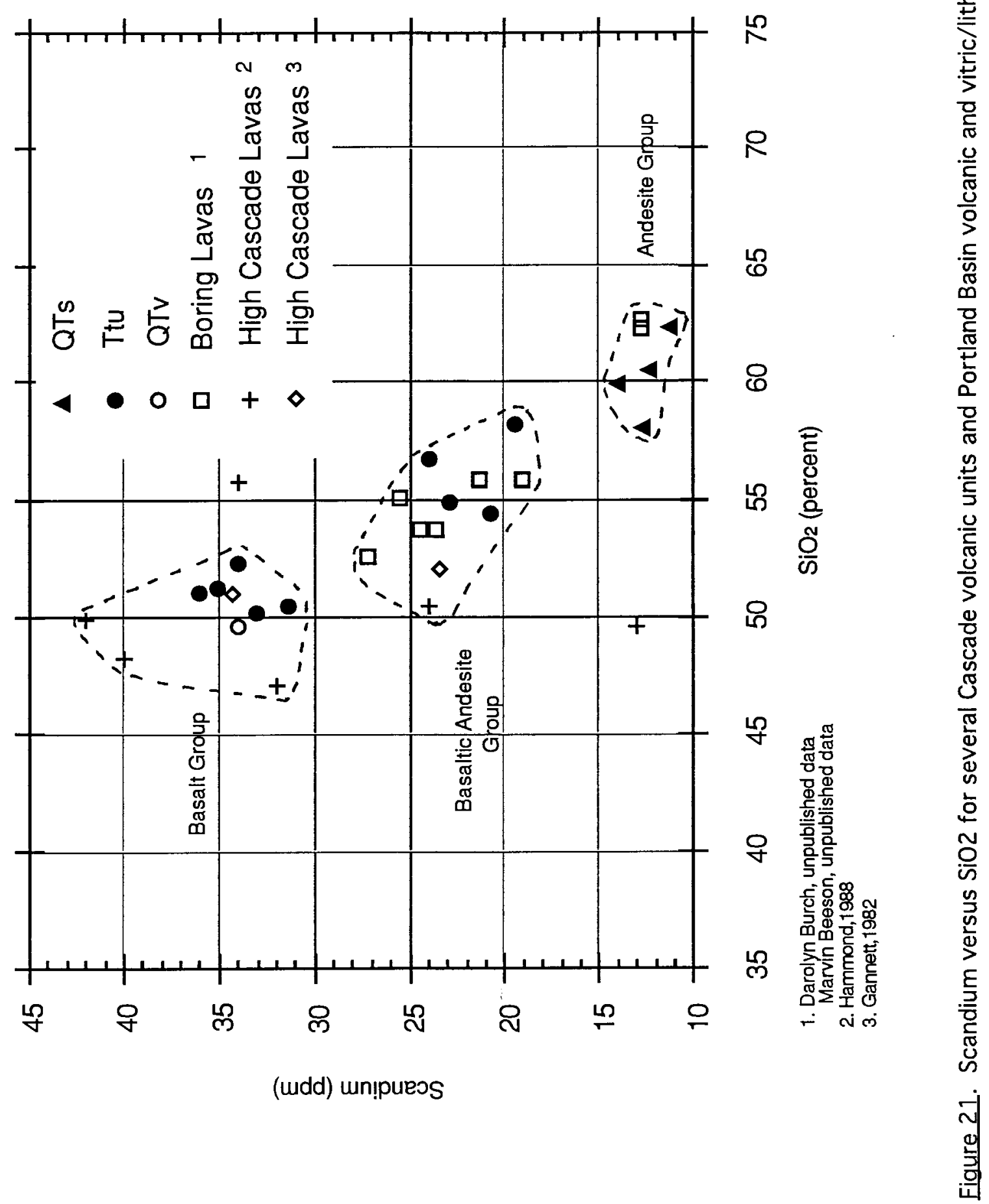


silica than the other Cascades derived sediments. The volcaniclastic deposits exhibit andesite lava composition.

In the previous discussion, the similarity of many chemical constituents between the upper Troutdale vitric and lithic sediments and Cascade Range volcanic rocks was established. The relationship between Cascade Mountain volcanic activity and some of the sediments within the Portland Basin has been recognized in previous studies (Allen, 1932; Trimble, 1963; Beaulieu, 1974; Sherrod and Smith, 1989).

A maximum age of approximately 6 million years has been proposed for the upper Troutdale vitric and lithic sand unit within the lower Columbia River Gorge area (Beeson and Tolan, 1984). The age of the deposit is probably closer to 4 million years within the study area (Marvin Beeson, personal communication, 1992).

Numerous volcanic deposits of basalt and basaltic andesite have been mapped within the Cascade Mountains adjacent to the Portland Basin. Many of the deposits are within the proposed age range. The 6 million year time period has been recognized as the approximate beginning of renewed volcanic activity within the Cascade Range which produced primarily basalt and andesite material (Priest and Vogt, 1983; Sherrod and Smith, 1989).

Nomenclature previously used for the approximately 6 million year old volcanic units adjacent to the Portland area include: upper Pliocene basalt and andesite (Wise,1969); upper Pliocene lavas (Priest and others, 1982); older basalt and basaltic andesite (Hammond and others, 1982); and Early High Cascades (Priest and Vogt, 1983).

The samples from Gannett (1982) were collected from units that Wise (1969) termed upper Pliocene volcanics in the Mt. Hood area. Upper Pliocene volcanics are described as younger than 5.8 million years (Gannett, 1982). The Hammond (1988) samples are from the Rhododendron Ridge area in the upper Clackamas River drainage. 
Three samples from Hammond (1988) are from the Gyp Point unit dated between 4.2 and 4.77 million years. Another sample is from the Cachebox Meadows unit in the same area and was dated at 4.18 million years (Hammond, 1988).

Sherrod and Smith (1989) have mapped several units of basalt and basaltic andesite as Tb1 adjacent to the Portland Basin. The Tb1 unit is assigned an age of 7 to 2 million years (Sherrod and Smith, 1989).

Early to middle Pliocene ages have been assigned to vitric and lithic sediments mapped adjacent to the study area in the Bull Run drainage (Beaulieu, 1974). Those vitric and lithic sediments have also been correlated with nearby volcanic rocks (Beaulieu, 1974). 


\section{AREA STRUCTURE}

\section{INTRODUCTION}

Few structural features have been previously identified within the study area. Several northeast and northwest trending lineaments were identified by Schlicker and Finlayson (1979). The north-northwest trending Sandy River fault was identified with gravity surveys by Davis (1987).

\section{SANDY RIVER FAULT}

The structural feature with the greatest amount of apparent displacement in the vicinity of the study area is the Sandy River fault. Exposures of the Sandy River fault were not observed during this study. However, the top of the high MgO (Sentinel Bluffs) Grande Ronde Basalt is offset approximately 245 meters between the Hood Acres Well in T1S/R4E,section 28DAA, and the Oregon Department of Geology Geothermal Test Well in T1S/R4E, section 11ACC. Geologic mapping during this study places the Sandy River fault east of the location proposed by Davis (1987). This is based on the apparent lack of north-northwest trending deformation in the sedimentary units between the Hood Acres Well and the Sandy River Canyon (Plates 1 and 2).

\section{TICKLE CREEK FAULT ZONE}

A dominant structural feature within the study area is a previously unrecognized northwest trending fault zone. The fault zone is herein called the Tickle Creek fault zone. The Tickle Creek fault zone is approximately $3 \mathrm{~km}$ wide and approximately $10 \mathrm{~km}$ long within the study area (Plate 1). The fault zone enters the study area at the southern 
boundary in the vicinity Deep Creek and trends approximately $\mathrm{N} 40^{\circ} \mathrm{W}$ to the vicinity of Boring, Oregon. The Tickle Creek fault zone comprises many short $(1 / 2-1 \mathrm{~km})$ northnorthwest, northwest, and northeast trending en echelon fault segments. Most of the fault segments are mapped on the basis of discontinuities in surface exposures or subsurface discontinuities in adjacent water wells, or both. The $\mathrm{N} 10^{\circ} \mathrm{W}$ fault segment in the northwest corner of section 7 in T2S, R4E was located by analyzing boundary conditions for a multiple well aquifer test (Grondin, unpublished data, 1988). Individual fault segments within the Tickle Creek fault zone exhibit apparent vertical offsets of 15 to 45 meters.

A small fault plane was located in an exposure of the upper Troutdale member within the Tickle Creek fault zone (Figure 22). The fault is located in a gravel quarry in T2S/R4E, section 21CCA (Plate 1). The fault strikes $N 35^{\circ} \mathrm{E}$ and dips southeast at 85 degrees. Slickensides on a thin red clay within the fault plane show a southwest rake of 55 degrees (Figure 23). The fault exhibits left-lateral movement with an apparent one foot vertical offset, based on the displacement of a sand lense in the quarry face.

The Tickle Creek fault zone appears to be an effective hydrologic boundary. Seasonal pumping of wells show markedly different responses across the structure in an area just south of Boring, Oregon.

\section{OTHER FAULTS}

Two additional faults are mapped within the study area. A northeast trending fault is mapped in T1S/R4E, section 32 and a northwest trending fault crossing T2S/R4E, section 1 and T1S/R4E, section 35 (Plate 1). The northeast trending fault is mapped on the basis of subsurface lithologic discontinuities (cross-section B-B') and topographic lineaments (Plates 1 and 2). The northwest trending fault is mapped on the 


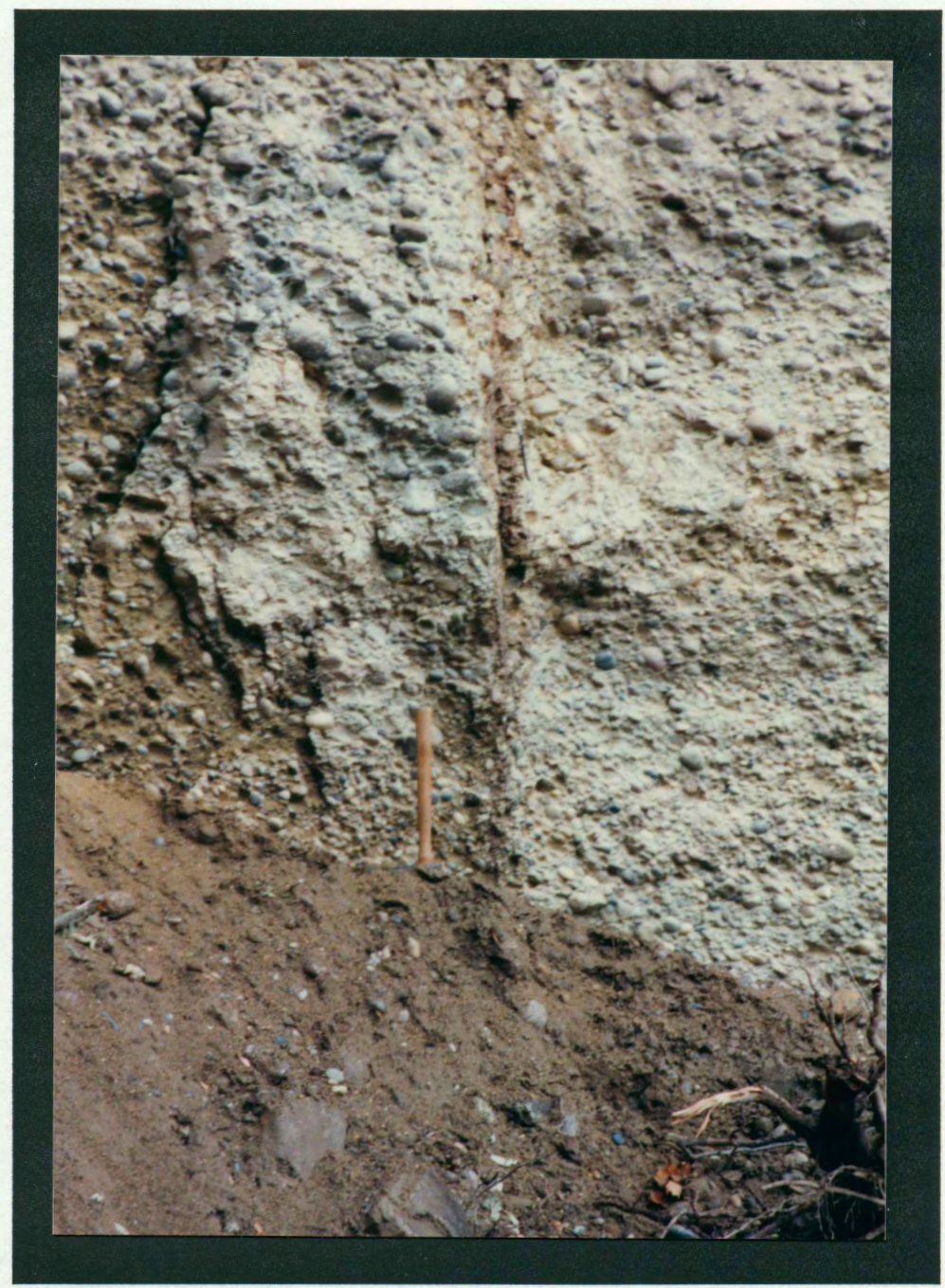

Figure 22. Small left-lateral strike-slip fault within the Columbia River facies of the upper Troutdale member. Located in T2S/R4E, section 21CCA. 


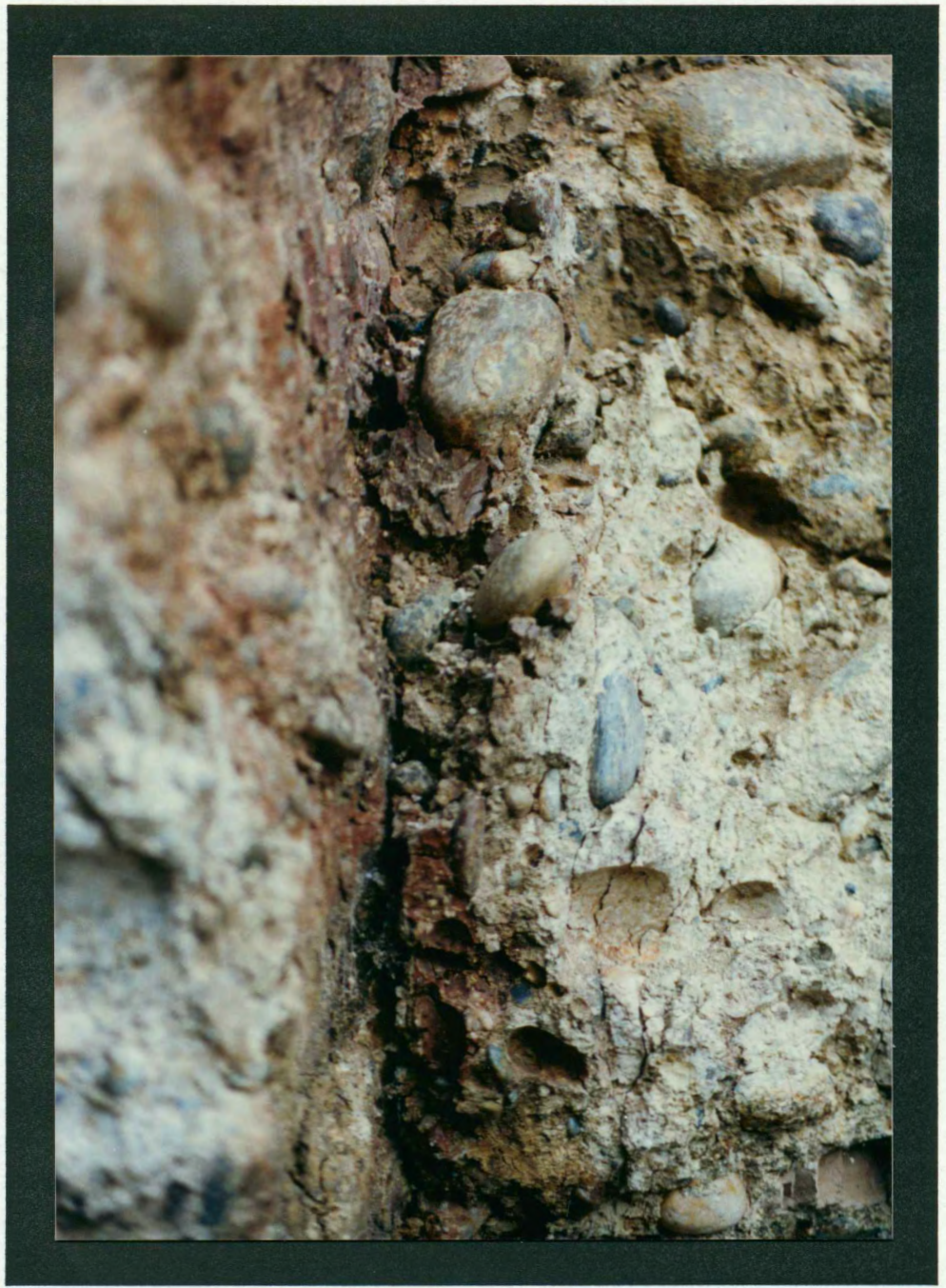

Figure 23. Close-up along strike of the slickensided surface on the quarry fault. Located in T2S/R4E, section 21CCA. 
basis of both surface and subsurface lithologic discontinuities and topographic lineaments (Plates 1 and 2). The northwest trending fault exhibits approximately 45 meters of apparent vertical offset.

\section{STRUCTURE CONTOUR MAP}

A structure contour map was constructed for the top of the lower Troutdale unit (Figure 24). It is recognized that the upper surface of the siltstone may be locally eroded. However, at the scale of the study area the surface appears to be a mappable structural surface. The contact is relatively easy to distinguish on water well reports because of the contrasting lithology between the upper and lower Troutdale members. Deformation associated with the Tickle Creek fault zone is apparent on the structure contour map. Narrowly spaced contour lines along the structure are oriented roughly 90 degrees to the regional strike. The area influenced by the Tickle Creek fault zone also appears as a high on the structure contour map. Another discontinuity on the structure map is probably associated with displacement on the northeast trending fault in T1S/R4E, section 32 .

\section{TECTONIC MODEL}

A right-lateral wrench fault model is herein proposed for the Tickle Creek fault zone. The right-lateral wrench interpretation is based on the geometry of the identified fault segments and the left-lateral movement exhibited by the northeast striking quarry fault. Figure 25 shows the classical right-lateral wrench model superimposed on mapped segments of the Tickle Creek fault zone. The overlay is oriented at $\mathrm{N} 40^{\circ} \mathrm{W}$. A remarkable match occurs between the quarry fault and the model's northeast trending conjugate shear ( $\left.\mathrm{R}^{\prime}\right)$. 


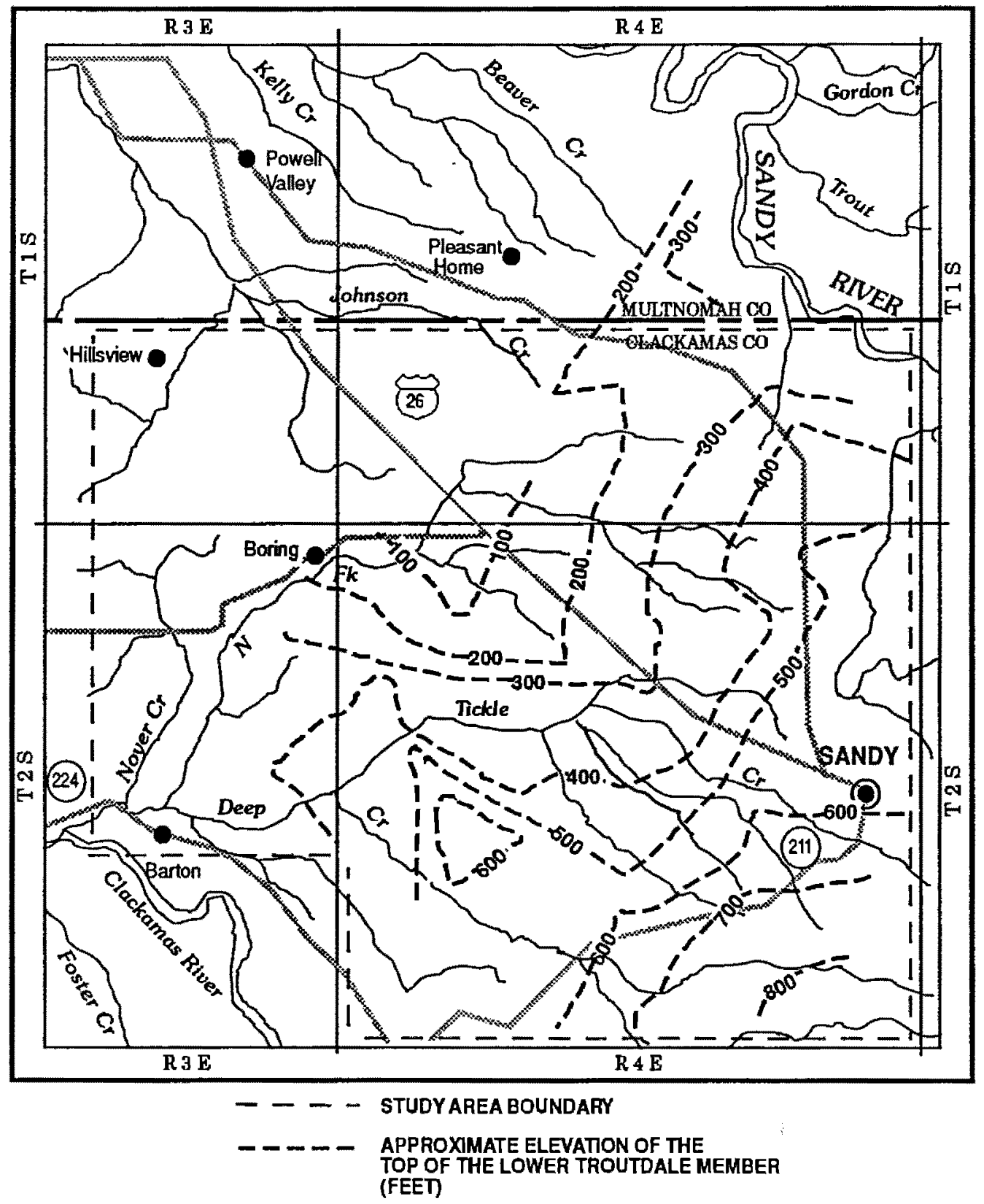

Figure 24. Structure contour map of the top of the lower Troutdale member. 


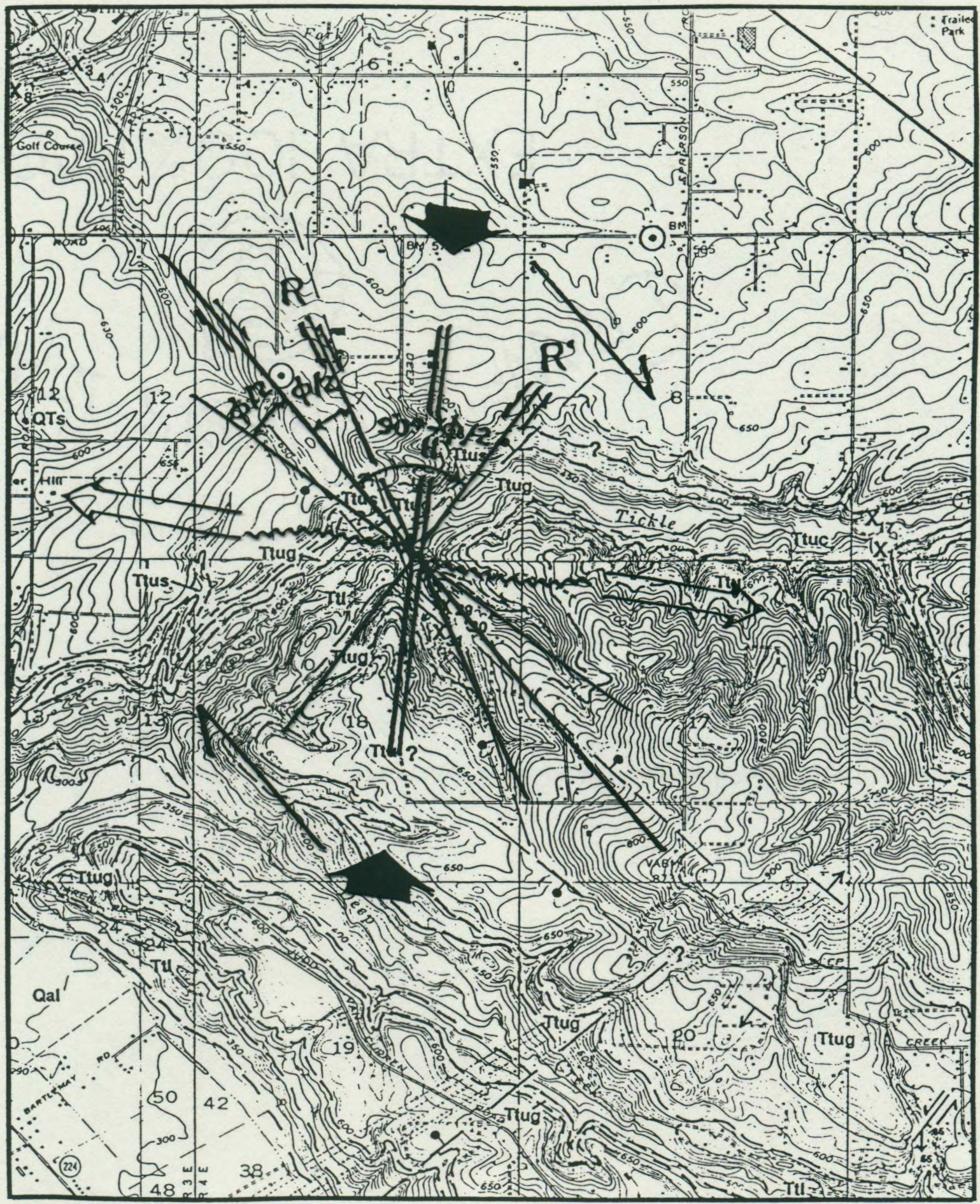

Figure 25. A comparison between a right-lateral wrench model and mapped fault segments along the Tickle Creek fault zone. 
On a regional scale, the Sandy River fault, Tickle Creek fault zone, and other smaller faults within the study area are interpreted herein as part of a complex boundary zone within the Portland Basin pull-apart structure. 


\section{GEOLOGIC HISTORY}

In middle to late Miocene time flows of the Columbia River Basalt Group entered the Portland area through a topographic low in the Miocene Cascade Range. Some low $\mathrm{MgO}$ and high MgO Grande Ronde Basalt as well as four flows of the Frenchman Springs Member of the Wanapum Basalt were deposited in the Portland Basin between 16 Ma and $15 \mathrm{Ma}$ (Beeson and others, 1989). The distribution of the Columbia River Basalt Group flows in the Portland area was influenced by the continual development of the Portland Hills-Clackamas River Structural Zone (Beeson and others, 1989). According to Beeson and others (1989), the continual development of a pull-apart basin along the Portland Hills-Clackamas River Structural Zone in the Portland area produced the topographic low in which the lavas flowed.

Deformation continued in the Portland area after the deposition of the Columbia River Basalt Group units. Concurrent with the post-Columbia River Basalt Group deformation was renewed activity in the Cascade Range that produced the Rhododendron Formation. Volcanic and volcaniclastic deposits of the Rhododendron Formation were erupted and deposited between $14 \mathrm{Ma}$ and 10.6 Ma (Gannett, 1982). Rhododendron Formation deposits appear to have reached only the easternmost part of the Portland Basin. Subsequent to the deposition of the Rhododendron Formation was the deposition of clay, silt, and fine sand of the lower member of the Troutdale Formation. There is evidence within a paleochannel of the Columbia River that the deposition of the Rhododendron Formation overlapped with the deposition of the lower member of the Troutdale Formation (Tolan, 1982).

Gradual subsidence of the Portland Basin continued between $13 \mathrm{Ma}$ and $6 \mathrm{Ma}$ (Beeson and others, 1989). This allowed a stream system carrying mainly clay, silt, 
and fine sand to deposit approximately 150 meters to 250 meters thickness of sediment within the southeast part of the Portland Basin during that time.

Sedimentation within the Portland Basin changed dramatically around $6 \mathrm{Ma}$. This was in response to increased volcanic activity in the adjacent Cascade Range. Starting around $6 \mathrm{Ma}$, increased volcanic activity in the Cascade volcanoes produced tremendous amounts of volcanic detritus that was transported and deposited by the Columbia River and other streams draining the Cascade Range. The material was derived from basalt and basaltic andesite eruptions during the development of the so called early High Cascades. At first, the volcanic material mixed with stream sediments of the Columbia River forming lenses of vitric and lithic sands within the coarse grained stream deposits. Eventually, the existing Columbia River Channel and streams draining the Cascade Range into the Portland area were aggraded with predominantly basalt and basaltic andesite detritus and volcanic flow deposits. Within the Cascade Range drainages, the volcanic flows form the proximal part of the volcanic units while some of the vitric and lithic sand and silt deposits in the eastern part of the Portland Basin represent the distal portion of those units. A few volcanic flows entered the Portland Basin near the eastern margin. Presumably, the flows originated in the Bull Run area. Up to approximately 50 meters thickness of the volcanic flows and volcanic sediments were deposited in the southeast part of the Portland Basin.

The episodic nature of the Cascade Range eruptions allowed the Columbia River to periodically influence the depositional record in the area. Mostly fine grained material derived from the Columbia River Basin was deposited periodically during the time that the major influence was the Cascade Range.

Continued volcanic activity in the Cascade Range concurrent with tectonic basin development allowed continued alluviation within the study area. The youngest sediments in the study area reflect a change in the depositional regime and eruptive material. The 
younger sediments are less well sorted and include andesite clasts not observed in the older Cascade Range derived Troutdale Formation material. The younger sedimentary unit locally includes volcaniclastic and debris flow material also not seen in the underlying sediments. Intercalated and overlying the sediments within the study area are the basaltic and basaltic andesite Boring Lava vents and deposits. 


\section{SUMMARY AND CONCLUSIONS}

The Portland Basin has been developing since at least the middle Miocene. Deposits within the southeast part of the basin have recorded most of the activity. The oldest deposits within the study area are lava flows of the Columbia River Basalt Group. Low MgO and high MgO Grande Ronde Basalt as well as four units of the Frenchman Springs Member of Wanapum Basalt are present. The four Frenchman Springs units include Ginkgo, Sand Hollow, Sentinel Gap, and Lyons Ferry.

The Columbia River Basalt Group is overlain in the study area by as much as 215 meters of micaceous clay, silt, and fine sand. The unit is termed lower Troutdale member in this report. Total exposed section for the lower Troutdale member is $\mathbf{5 5}$ meters located in the Sandy River canyon.

The lower Troutdale member is overlain by two distinct facies of the upper Troutdale member. One facies is characteristically a quartzite bearing pebble to cobble conglomerate with a matrix of micaceous, arkosic sand. The other facies is typically a vitric and lithic sand with varying amounts of pebble to cobble clasts. Fine grained constituents of the Columbia River facies of the upper Troutdale member are chemically very similar to the lower Troutdale member. The similarity occurs because both deposits are products of the Columbia River drainage. The maximum thickness of a sampled section of the Columbia River facies is 40 meters.

Vitric and lithic sands of the upper Troutdale member have been the subject of study for years. The vitric and lithic sand facies occurs within the study area in three depositional forms. The first is typically as a 15 to 40 meters thick deposit of medium to coarse grained vitric or vitric and lithic sand with occasional Boring Lava type clasts. The second form is medium to coarse grained vitric or lithic sand with basalt and 
quartzite clasts commonly forming the lower part of the deposit. The second form probably represents incorporation and mixing of the Columbia River type clasts with the Cascade Range derived vitric and lithic sands. The third occurrence of the vitric and lithic sand facies is as interbedded layers within the The Columbia River facies. This occurrence probably represents the direct incorporation of Cascade Range derived material into the Columbia River stream system.

Boring Lava flows are poorly exposed within the study area. Water well report data suggest that numerous flows and/or intrusions are present at depth. Boring Lava pyroclastic debris was identified at the base of a Boring vent located $3 \mathrm{~km}$ northnortheast of Boring, Oregon. A Boring Lava flow overlying vitric sand was sampled and chemically analyzed during this study. The results of the chemical analysis indicate that the flow is chemically similar to the vitric sand unit.

Distinct post-Troutdale deposits were recognized during this study. Up to 67 meters of the unit are identified in the northern part of the study area. The postTroutdale deposits are generally distinguished from the upper Troutdale member by the abundance of coarse grained volcanic clasts, a greater degree of weathering, and lack of sorting. Mudflows and debris flows are also present within the unit in the northern part of the study area.

Trace element and major oxide analyses of sediments and volcanic material from the study area revealed two chemically distinct provenances for the material. The Columbia River Basin and the Cascade Range appear to have contributed material to the study area. The Columbia River Basin derived sediments are characteristically higher in thorium, lanthanum, and silica.

The Cascade Range derived material are further divided into three distinct chemical groupings. The groupings generally reflect the chemical differences between basalt, basaltic andesite, and andesite rocks. The basalt group includes vitric and lithic 
upper Troutdale member material and a Boring Lava flow. The basalt group is chemically similar to Cascade Range volcanic units. The basaltic andesite group also consists of vitric and lithic material, but those samples are more closely associated with Portland Basin Boring Lavas.

The debris flow deposits of the post-Troutdale unit are typically lower in chromium and scandium, and higher in silica than the other Cascade Range derived material. The deposits are similar to andesite lava composition.

An age range of 6 to 2 million years was proposed in previous studies for the upper Troutdale member. Numerous possible source rocks have been identified as being within a 7 to 2 million year age range and adjacent to the Portland Basin. Pliocene volcanic activity within the present Bull Run and Sandy River drainages are likely sources for most of the vitric and lithic silt and sand deposits within the study area.

Tectonic activity has been ongoing within the southeast part of the Portland Basin since the middle Miocene. Major structural features within the southeast part of the basin include the north-northwest trending Sandy River fault and the previously unrecognized northwest trending Tickle Creek fault zone. This study places the Sandy River fault east of the previously mapped location. Offset across the Sandy River fault displaces Columbia River Basalt Group units approximately 245 meters higher on the east side. The Tickle Creek fault zone is interpreted as a right-lateral wrench fault. A small left-lateral strike-slip fault identified during this study is interpreted as a conjugate shear within the Tickle Creek fault zone.

All of the structural features identified within the study area are interpreted as being part of a complex boundary zone within the Portland Basin pull-apart structure. 


\section{REFERENCES}

Allen, J. R., 1932, Contributions to the structure, stratigraphy, and paleontology of the lower Columbia River Gorge: M. A. thesis (unpublished), Univ. of Oregon, Eugene, $96 \mathrm{p}$.

Allen, J. R., 1975, Volcanoes of the Portland area, Oregon: Ore Bin, vol. 37, no. 9, pp. 145-157.

Anderson, J. L., 1978, Structure and stratigraphy of the Columbia River Basalt Group in the Clackamas River Drainage: M.S. thesis (unpublished), Portland State University, Portland, Oregon.

Beaulieu, J. D., 1974, Geologic hazards of the Bull Run Watershed, Multnomah and Clackamas, Oregon: Oregon Department of Geology and Mineral Industries Bulletin 82, $77 \mathrm{p}$.

Beeson, M. H., Fecht, K. R., Reidel, S. P., and Tolan, T. L., 1985, Regional correlations within the Frenchman Springs Member of the Columbia River Basalt Group: New insights into the middle Miocene tectonics of northwestern Oregon: Oregon Department of Geology and Mineral Industries, Oregon Geology, vol. 47, no. 8, pp. 87-96.

Beeson, M. H., Johnson, A. G., and Moran, M. R., 1975, Portland Environmental Geology-Fault Identification: final technical report, U.S. Geological Survey contract no. 14-08-0001-14832, Geology Department, Portland State University, Portland, Oregon.

Beeson, M. H., and Tolan,T. L., 1989, The Columbia River Basalt Group in the Cascade Range: a middle Miocene reference datum for structural analysis, in proceedings of Workshop XLIV, Geological, geophysical, and Tectonic setting of the Cascade Range: U.S. Geological Survey Open File Report 89-178.

Beeson, M. H., Tolan, T. L., and Anderson, J. L., 1989a, The Columbia River Basalt Group in western Oregon; Geologic structures and other factors that controlled flow emplacement patterns, in Volcanism and Tectonics in the Columbia River Flood Basin Province, Reidel, S. P., and Tolan, T. L., eds., Geological Society of America Special Paper 239, pp. 223-246.

Beeson, M. H., Tolan, T. L., and Madin, I. P., 1989b, Geologic map of the Lake Oswego Quadrangle, Clackamas, Multnomah, and Washington Counties, Oregon, Oregon Department of Geology and Mineral Industries Geological Map Series, GMS-59.

Beeson, M. H., Tolan, T. L., and Madin, I. P., 1991, Geologic map of the Portland Quadrangle, Multnomah, and Washington Counties, Oregon and Clark County, Washington: Oregon Department of Geology and Mineral Industries Geological Map Series, GMS-75. 
Beeson, P. T., 1990, Gravity maps, models, and analyses of the greater Portland area, Oregon: M.S. thesis (unpublished), Portland State University, Portland, Oregon, $79 \mathrm{p}$.

Benson, G. T., and Donovan, J. C., 1974, Preliminary tectonic map of the greater Portland area: in A preliminary geological investigation of the ground effects of earthquakes in the Portland metropolitan area, Oregon: Oregon Department of Geology and Mineral Industries Open File Report 0-74-1.

Davis, S. A., 1987, An analysis of the eastern margin of the Portland Basin using gravity surveys: M.S. thesis (unpublished), Portland State University, Portland, Oregon.

Foxworthy, B.L., Hogenson, G.M., and Hampton, E.R., 1964, Records of wells and springs, water levels, and chemical quality of ground water in the East Portland area, Oregon: Oregon Water Resources Department Ground Water Report No. 3, $79 \mathrm{p}$.

Gannett, M. W., 1982, A geochemical study of the Rhododendron and Dalles Formations in the area of Mount Hood, Oregon: M.S. thesis (unpublished), Portland State University, Portland, Oregon.

Hammond, P. E., Geyer, K. M., and Anderson, J. L., 1982, Preliminary geologic map and cross sections of the upper Clackamas and North Santiam Rivers area, northern Oregon Cascade Range: Portland, Oreg.: Portland State University Earth Sciences Department, scale 1:62,500.

Hammond, P. E., 1988, Status report on detailed stratigraphic mapping of High Cascade volcanic units and Rhododendron Formation in the northwest-trending fault zone (Rhododendron Ridge) of the upper Clackamas River area, northern Oregon Cascade Range: Geology Department, Portland State University, Portland, Oregon, $10 \mathrm{p}$.

Hogenson, G. M., and Foxworthy, B.L., 1965, Ground water in the East Portland area, Oregon: U.S. Geological Survey Water Supply Paper 1793, 78 p.

Hodge, E. T., 1938, Geology of the lower Columbia River: Geological Society of America Bulletin, vol. 49, no. 6, pp. 831-930.

Leonard, A. R., and Collins, C. A., 1983, Ground water in the northern part of Clackamas County, Oregon: Oregon Water Resources Department Ground Water Report No. $29,85 \mathrm{p}$.

Madin, I. P., 1990, Earthquake-hazard geology maps of the Portland Metropolitan area, Oregon: Oregon Department of Geology and Mineral Industries Open File Report 0-90-2.

McCarthy, K. A., and Anderson, D. B., 1990, Ground-Water data for the Portland Basin, Oregon and Washington: U.S. Geological Survey Open-File Report 90-126, 56 p.

Mundorff, M. J., 1964, Geology and ground water conditions of Clark County, Washington, with a description of a major alluvial aquifer along the Columbia River: U.S. Geological Survey Water Supply Paper 1600, 268 p. 
Piper, A. M., 1942, Ground-Water resources of the Willamette Valley, Oregon: U.S. Geological Survey Water Supply Paper 890. 194 p.

Priest, G. R., and Vogt, B. F., eds.,1983, Geology and geothermal resources of the central Oregon Cascade Range: Oregon Department of Geology and Mineral Industries Special Paper 15, 123 p.

Schlicker, H. G., and Finlayson, C. T., 1979, Geology and geologic hazards of Northwestern Clackamas County, Oregon: Oregon Department of Geology and Mineral Industries Bulletin 99, $79 \mathrm{p}$.

Sherrod, D. R., and Smith, J. G., 1989, Preliminary map of upper Eocene to Holocene volcanic and related rocks of the Cascade Range, Oregon: U.S. Geological Survey Open-File Report 98-14.

Swanson, R. D., 1986, A stratigraphic and geochemical study of the Troutdale Formation and Sandy River mudstone in the Portland Basin and lower Columbia River Gorge: M.S. thesis (unpublished), Portland State University, Portland, Oregon.

Tolan, T. L., 1982, The stratigraphic relationships of the Columbia River Basalt Group in the lower Columbia River Gorge of Oregon and Washington: M.S. thesis (unpublished), Portland State University, Portland, Oregon, $151 \mathrm{p}$.

Tolan, T. L., and Beeson, M. H., 1984, Intracanyon flows of the Columbia River Basalt Group in the lower Columbia River Gorge and their relationship to the Troutdale Formation: Geological Society of America Bulletin, vol. 95, no. 4 pp. 463-477.

Tolan, T. L., Reidel, S. P., Beeson, M. H., Anderson, J. L., Fecht, K. R., Swanson, D. A., 1989 , Revisions to the estimates of the areal extent and volume of the Columbia River Basalt Group, in Volcanism and Tectonics in the Columbia River Flood Basin Province: Reidel, S. P., and Tolan, T. L., eds., Geological Society of America Special Paper 239, pp. 1-20.

Treasher, R. C., 1942, Geologic history of the Portland area: Oregon Department of Geology and Mineral Industries Short Paper 7, $17 \mathrm{p}$.

Trimble, D. E., 1957, Geology of the Portland Quadrangle, Oregon-Washington: U.S. Geological Survey Map GQ-104.

Trimble, D. E., 1963, Geology of Portland, Oregon and adjacent areas: U.S. Geological Survey Bulletin 1119, $119 \mathrm{p}$.

Wilkinson, W. D., Lowry, W. D., and Baldwin, E. M., 1946, Geology of the St. Helens Quadrangle, Oregon: Oregon Department of Geology and Mineral Industries Bulletin no. 31 .

Wise, W. S., 1969, Geology and petrology of the Mt. Hood area: A study of High Cascade volcanism: Geological Society of America Bulletin, v. 80, no. 6, pp. 969-1006.

Yelin, T. S., and Patton, H. J., 1991, Seismotectonics of the Portland, Oregon region: Bulletin of the Seismological Society of America, v. 81, no. 1, pp. 109-130. 
APPENDIX A

GEOCHEMICAL ANALYSES 
Two experiments were conducted using instrumental neutron activation analysis. The first experiment was done in conjunction with the advanced geochemistry course at Portland State University. The second experiment was conducted as part of this thesis research. Both experiments followed standard experimental procedures, and utilized U.S. Geological Survey rock standards for comparison.

The samples and standards were irradiated for 1 hour at $250 \mathrm{kw}$ in the Reed College TRIGA MARK II Reactor. At four to five days and approximately twenty-one days after irradiation, the samples and standards were placed in a gamma-ray detector and the energy spectra were counted. A Ge-Li detector was used in the first experiment and a high purity $\mathrm{Ge}$ detector was used for the second experiment.

The major element analysis was conducted by Washington State University staff. The WSU analysis uses an $\mathrm{x}$-ray fluorescence technique. 
Sample Sample

Name Number

Location

Unit

Th

La

\begin{tabular}{|c|c|c|c|c|c|c|c|}
\hline$K L-1$ & 1 & 2S/4E-9CCC & Ttuc & 5.90 & 0.30 & 22.60 & 0.50 \\
\hline$K L-2$ & 2 & $2 \mathrm{~S} / 4 \mathrm{E}-8 \mathrm{BAA}$ & Ttuc & 6.20 & 0.30 & 21.00 & 0.50 \\
\hline$K L-3$ & 3 & $2 S / 3 E-1 A C D$ & QTs & 3.17 & 0.18 & 17.40 & 0.40 \\
\hline$K L-4$ & 4 & $2 S / 3 E-1 A C D$ & QTs & 4.20 & 0.20 & 21.10 & 0.40 \\
\hline$K L-5$ & 5 & $2 S / 3 E-1 B B A$ & QTV & 1.57 & 0.13 & 12.60 & 0.30 \\
\hline$K L-6$ & 6 & $2 S / 3 E-15 D B B$ & QTb & 1.51 & 0.13 & 15.80 & 0.30 \\
\hline $\mathrm{KL}-7$ & 7 & $2 S / 3 E-14 C A B$ & 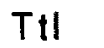 & 9.50 & 0.40 & 34.10 & 0.70 \\
\hline$K L-8$ & 8 & $2 S / 3 E-1 C A A$ & Tiu & 8.48 & 0.12 & 34.31 & 0.07 \\
\hline$K L-9$ & 9 & $2 S / 3 E-1 C C B$ & Ttus & 2.11 & 0.00 & 9.46 & 0.16 \\
\hline$K L-10$ & 10 & $2 S / 3 E-1 C C B$ & Ttuc & 11.61 & 0.13 & 41.70 & 0.06 \\
\hline$K L-11$ & 11 & $2 \mathrm{~S} / 3 \mathrm{E}-1 \mathrm{CCB}$ & Ttuc & 12.39 & 0.13 & 38.52 & 0.05 \\
\hline $\mathrm{KL}-12$ & 12 & $2 \mathrm{~S} / 3 \mathrm{E}-1 \mathrm{CCB}$ & Ttuc & 11.04 & 0.11 & 46.08 & 0.06 \\
\hline$K L-13$ & 13 & $2 S / 3 E-11 A D B$ & Ttug & 7.94 & 0.09 & 33.35 & 0.06 \\
\hline$K L-14$ & 14 & $2 S / 3 E-11 A D B$ & $T+1$ & 8.89 & 0.11 & 26.25 & 0.04 \\
\hline$K L-15$ & 15 & 2S/4E-7BDC & QTs & 4.02 & 0.12 & 25.47 & 0.05 \\
\hline$K L-16$ & 16 & $2 S / 4 E-7 B D C$ & $T t l$ & 12.53 & 0.15 & 39.80 & 0.07 \\
\hline $\mathrm{KL}-17$ & 17 & 2S/4E-9CCB & Ttuc & 7.99 & 0.09 & 38.82 & 0.06 \\
\hline$K L=18$ & 18 & $2 S / 3 E-11 B D A$ & Ttus & 6.96 & 0.10 & 24.13 & 0.05 \\
\hline$K L-19$ & 19 & 2S/4E-8BAA & QTV & 2.97 & 0.07 & 17.00 & 0.03 \\
\hline$K L-20$ & 20 & $2 \mathrm{~S} / 4 \mathrm{E}-8 \mathrm{BAA}$ & QTV & 2.75 & 0.09 & 18.05 & 0.06 \\
\hline$K L-21$ & 21 & $2 \mathrm{~S} / 4 \mathrm{E}-8 \mathrm{BAA}$ & QTs & 8.22 & 0.16 & 26.45 & 0.05 \\
\hline$K L-22$ & 22 & $2 S / 4 E-8 B A A$ & Ttuc & 8.32 & 0.14 & 34.12 & 0.06 \\
\hline$K L-23$ & 23 & $2 S / 4 E-8 B A A$ & Ttu & 7.47 & 0.11 & 30.85 & 0.07 \\
\hline$K L-24$ & 24 & $2 \mathrm{~S} / 4 \mathrm{E}-8 \mathrm{BAA}$ & Ttu & 8.75 & 0.10 & 35.11 & 0.06 \\
\hline$K L-25$ & 25 & $2 \mathrm{~S} / 4 \mathrm{E}-7 \mathrm{BAA}$ & Ttu & 3.72 & 0.11 & 30.44 & 0.04 \\
\hline$K L-26$ & 26 & $2 \mathrm{~S} / 5 \mathrm{E}-31 \mathrm{BBA}$ & $T t I$ & 9.26 & 0.17 & 3.01 & 0.01 \\
\hline$K L-27$ & 27 & $2 S / 4 E-14 C A A$ & Ttus & 5.63 & 0.14 & 27.13 & 0.04 \\
\hline$K L-28$ & 28 & 2S/4E-7DBA & Ttus & 4.99 & 0.16 & 56.43 & 0.07 \\
\hline$K L-29$ & 29 & $2 S / 4 E-18 A A C$ & Ttu & 7.88 & 0.09 & 30.06 & 0.05 \\
\hline$K L-30$ & 30 & $2 S / 4 E-18 A A C$ & Ttu & 8.78 & 0.10 & 44.29 & 0.06 \\
\hline$K L-31$ & 31 & $2 S / 4 E-18 A B D$ & Ttuc & 11.15 & 0.11 & 45.29 & 0.06 \\
\hline$K L-32$ & 32 & $2 S / 4 E-28 A A B$ & Ttu & 9.02 & 0.00 & 45.76 & 0.06 \\
\hline$K L-33$ & 33 & $2 S / 4 E-28 A A B$ & Ttuc & 15.20 & 0.13 & 66.09 & 0.07 \\
\hline$K L-34$ & 34 & 1S/3E-26DAD & Ttu? & 10.83 & 0.13 & 29.45 & 0.04 \\
\hline$K L-35$ & 35 & $2 S / 4 E-9 D C B$ & Ttu & 8.70 & 0.13 & 37.45 & 0.00 \\
\hline$K L-36$ & 36 & $1 \mathrm{~S} / 4 \mathrm{E}-36 \mathrm{ABA}$ & QTV & 3.28 & 0.12 & 18.92 & 0.00 \\
\hline$K L=37$ & 37 & $1 \mathrm{~S} / 3 \mathrm{E}-26 \mathrm{ABD}$ & QTV & 3.84 & 0.12 & 29.69 & 0.05 \\
\hline$K L-38$ & 38 & $2 S / 4 E-10 D B C$ & बाs & 4.54 & 0.11 & 18.96 & 0.05 \\
\hline$K L=39$ & 39 & $2 \mathrm{~S} / 4 \mathrm{E}-10 \mathrm{DBC}$ & Ttu & 7.71 & 0.13 & 31.66 & 0.06 \\
\hline$K L-40$ & 40 & $2 S / 4 E-10 D B C$ & Ttu & 5.35 & 0.19 & 26.69 & 0.07 \\
\hline$K L-41$ & 41 & $2 \mathrm{~S} / 4 \mathrm{E}-10 \mathrm{DBC}$ & Ttu & 9.59 & 0.00 & 36.06 & 0.00 \\
\hline$K L-42$ & 42 & $2 S / 4 E-10 D B C$ & $T t l$ & 6.97 & 0.09 & 25.17 & 0.04 \\
\hline$K L-43$ & 43 & $2 S / 4 E-10 D B C$ & Ttu & 4.15 & 0.12 & 23.04 & 0.05 \\
\hline$K L-44$ & 44 & $2 \mathrm{~S} / 3 \mathrm{E}-11 \mathrm{BDA}$ & Ttu & 5.25 & 0.00 & 21.22 & 0.05 \\
\hline
\end{tabular}

All elemental values reported in ppm, except $\mathrm{Fe}, \mathrm{Na}$, and $\mathrm{K}$.

Reported error range is 1 standard deviation.

NR means the value was not reported. 
Sample

Name

$\mathrm{Ta}$

Cs

$\mathrm{Ce}$

$\mathrm{Hf}$

\begin{tabular}{|c|c|c|c|c|c|c|c|c|}
\hline$K L-1$ & 1.00 & 0.20 & 1.70 & 0.20 & 38.00 & 1.50 & 6.10 & 0.40 \\
\hline$K L-2$ & 0.88 & 0.19 & 1.80 & 0.20 & 42.40 & 1.50 & 5.90 & 0.40 \\
\hline KL-3 & 0.50 & 0.12 & 0.00 & 0.00 & 36.20 & 1.30 & 3.60 & 0.30 \\
\hline KL- 4 & 0.71 & 0.13 & 0.70 & 0.15 & 41.70 & 1.40 & 3.90 & 0.30 \\
\hline KL-5 & 0.32 & 0.09 & 0.00 & 0.00 & 21.80 & 0.90 & 2.35 & 0.19 \\
\hline KL-6 & 0.37 & 0.11 & 0.00 & 0.00 & 32.60 & 1.20 & 3.20 & 0.20 \\
\hline KL-7 & 1.05 & 0.19 & 4.10 & 0.20 & 68.00 & 2.00 & 5.80 & 0.40 \\
\hline KL- 8 & 1.01 & 0.05 & 2.64 & 0.20 & 52.79 & 0.57 & 6.14 & 0.17 \\
\hline$K L-9$ & 0.26 & 0.00 & 1.43 & 0.00 & 17.05 & 0.61 & 2.40 & 0.26 \\
\hline$K L-10$ & 1.36 & 0.07 & 6.54 & 0.23 & 76.08 & 0.70 & 4.07 & 0.15 \\
\hline$K L-11$ & 1.19 & 0.10 & 8.67 & 0.22 & 71.51 & 0.58 & 4.43 & 0.09 \\
\hline $\mathrm{KL}-12$ & 1.17 & 0.08 & 4.61 & 0.20 & 79.24 & 0.66 & 5.78 & 0.12 \\
\hline$K L-13$ & 1.17 & 0.08 & 2.26 & 0.16 & 51.07 & 0.50 & 5.15 & 0.17 \\
\hline$K L-14$ & 1.10 & 0.07 & 4.93 & 0.42 & 51.05 & 0.63 & 3.20 & 0.12 \\
\hline$K L-15$ & 0.84 & 0.07 & 1.39 & 0.22 & 37.17 & 0.54 & 4.29 & 0.14 \\
\hline$K L-16$ & 1.53 & 0.18 & 5.40 & 0.24 & 83.08 & 0.67 & 6.26 & 0.14 \\
\hline $\mathrm{KL}-17$ & 1.55 & 0.17 & 4.78 & 0.21 & 40.51 & 0.67 & 4.19 & 0.14 \\
\hline$K L-18$ & 0.76 & 0.06 & 3.82 & 0.26 & 43.41 & 0.61 & 3.65 & 0.21 \\
\hline KL-19 & 0.58 & 0.04 & 0.71 & 0.18 & 30.95 & 0.45 & 3.23 & 0.14 \\
\hline$K L-20$ & 0.67 & 0.08 & 0.81 & 0.00 & 29.32 & 0.46 & 3.63 & 0.19 \\
\hline$K L-21$ & 1.20 & 0.05 & 3.59 & 0.21 & 43.69 & 0.62 & 6.17 & 0.19 \\
\hline KL-22 & 1.13 & 0.07 & 4.43 & 0.24 & 62.31 & 0.74 & 4.49 & 0.25 \\
\hline$K L-23$ & 1.46 & 0.11 & 3.28 & 0.26 & 52.73 & 0.66 & 5.25 & 0.26 \\
\hline$K L-24$ & 1.38 & 0.09 & 4.69 & 0.24 & 58.88 & 0.62 & 4.54 & 0.18 \\
\hline KL-25 & 0.75 & 0.08 & 2.03 & 0.26 & 50.27 & 0.55 & 4.29 & 0.14 \\
\hline$K L-26$ & 2.36 & 0.08 & 0.99 & 0.36 & 9.54 & 0.64 & 10.04 & 0.17 \\
\hline $\mathrm{KL}-27$ & 1.56 & 0.10 & 2.43 & 0.55 & 39.59 & 0.62 & 5.21 & 0.15 \\
\hline$K L-28$ & 2.05 & 0.19 & 2.28 & 0.33 & 26.05 & 0.73 & 4.77 & 0.19 \\
\hline$K L-29$ & 0.83 & 0.05 & 2.69 & 0.17 & 55.39 & 0.50 & 3.66 & 0.11 \\
\hline KL-30 & 3.22 & 0.30 & 6.29 & 0.24 & 37.34 & 0.72 & 4.41 & 0.17 \\
\hline$K L-31$ & 1.51 & 0.07 & 5.77 & 0.20 & 71.01 & 0.67 & 5.54 & 0.12 \\
\hline$K L-32$ & 1.02 & 0.12 & 3.12 & 0.17 & 0.00 & 0.00 & 4.14 & 0.13 \\
\hline$K L-33$ & 1.73 & 0.15 & 6.00 & 0.24 & 118.33 & 0.76 & 12.19 & 0.16 \\
\hline$K L-34$ & 1.47 & 0.06 & 3.95 & 0.26 & 60.46 & 0.67 & 7.85 & 0.12 \\
\hline$K L-35$ & 1.09 & 0.08 & 4.09 & 0.21 & 64.81 & 0.64 & 5.16 & 0.13 \\
\hline$K L-36$ & 0.61 & 0.05 & 0.81 & 0.21 & 32.31 & 0.44 & 3.23 & 0.07 \\
\hline$K L-37$ & 0.83 & 0.08 & 2.11 & 0.00 & 54.99 & 0.75 & 4.59 & 0.16 \\
\hline KL-38 & 1.12 & 0.00 & 1.21 & 0.27 & 31.38 & 0.70 & 5.83 & 0.17 \\
\hline$K L-39$ & 1.15 & 0.05 & 3.66 & 0.23 & 52.37 & 0.61 & 5.20 & 0.12 \\
\hline$K L-40$ & 0.97 & 0.16 & 3.61 & 0.55 & 40.48 & 0.78 & 4.86 & 0.21 \\
\hline$K L-41$ & 1.22 & 0.00 & 5.50 & 0.00 & 63.69 & 0.00 & 4.51 & 0.00 \\
\hline$K L-42$ & 1.08 & 0.07 & 2.19 & 0.14 & 45.02 & 0.42 & 3.75 & 0.09 \\
\hline$K L-43$ & 1.01 & 0.11 & 2.25 & 0.39 & 40.66 & 0.62 & 4.97 & 0.29 \\
\hline$K L-44$ & 0.82 & 0.00 & 2.71 & 0.00 & 34.92 & 0.00 & 3.92 & 0.00 \\
\hline
\end{tabular}


Sample

Name

Sm

Tb

$\mathrm{Ba}$

$\mathrm{Cr}$

\begin{tabular}{|c|c|c|c|c|c|c|c|c|}
\hline$K L-1$ & 4.37 & 0.05 & 0.66 & 0.08 & 300.00 & 70.00 & 100.00 & 20.00 \\
\hline$K L-2$ & 4.19 & 0.05 & 0.71 & 0.13 & 340.00 & 70.00 & 76.00 & 17.00 \\
\hline KL-3 & 3.88 & 0.04 & 0.50 & 0.07 & 320.00 & 60.00 & 38.00 & 9.00 \\
\hline$K L-4$ & 3.76 & 0.03 & 0.55 & 0.06 & 330.00 & 60.00 & 20.00 & 5.00 \\
\hline$K L-5$ & 3.38 & 0.03 & 0.39 & 0.05 & 190.00 & 50.00 & 39.00 & 9.00 \\
\hline$K L-6$ & 4.15 & 0.04 & 0.46 & 0.06 & 300.00 & 60.00 & 120.00 & 30.00 \\
\hline KL-7 & 6.08 & 0.06 & 1.05 & 0.09 & 720.00 & 90.00 & 68.00 & 15.00 \\
\hline$K L-8$ & 4.72 & 0.00 & 0.82 & 0.04 & 655.00 & 9.64 & 38.29 & 1.02 \\
\hline KL-9 & 2.59 & 0.00 & 0.92 & 0.00 & 333.00 & 10.61 & 204.90 & 2.64 \\
\hline$K L-10$ & 5.49 & 0.00 & 0.97 & 0.00 & 723.00 & 10.78 & 85.37 & 1.20 \\
\hline$K L-11$ & 5.05 & 0.00 & 0.85 & 0.04 & 616.00 & 9.50 & 87.24 & 1.05 \\
\hline$K L-12$ & 6.76 & 0.00 & 1.11 & 0.05 & 717.00 & 9.70 & 79.25 & 1.14 \\
\hline$K L-13$ & 3.75 & 0.00 & 0.64 & 0.04 & 489.00 & 13.65 & 62.58 & 1.33 \\
\hline$K L-14$ & 3.22 & 0.00 & 0.65 & 0.04 & 599.00 & 10.52 & 119.82 & 2.08 \\
\hline$K L-15$ & 4.57 & 0.00 & 0.68 & 0.13 & 503.00 & 17.48 & 90.06 & 1.15 \\
\hline$K L-16$ & 8.18 & 0.00 & 1.37 & 0.00 & 705.00 & 12.25 & 73.97 & 1.24 \\
\hline $\mathrm{KL}-17$ & 3.32 & 0.00 & 0.77 & 0.05 & 563.00 & 0.00 & 75.47 & 1.13 \\
\hline$K L-18$ & 2.92 & 0.00 & 0.69 & 0.05 & 501.00 & 10.05 & 125.70 & 1.20 \\
\hline$K L-19$ & 3.17 & 0.00 & 0.50 & 0.03 & 414.00 & 7.14 & 40.49 & 0.79 \\
\hline$K L-20$ & 2.89 & 0.00 & 0.50 & 0.12 & 237.00 & 9.55 & 45.41 & 0.90 \\
\hline$K L-21$ & 2.96 & 0.00 & 0.58 & 0.04 & 436.00 & 10.22 & 107.70 & 1.18 \\
\hline$K L-22$ & 5.12 & 0.00 & 0.92 & 0.05 & 509.00 & 17.60 & 90.88 & 1.38 \\
\hline$K L-23$ & 4.69 & 0.00 & 0.81 & 0.05 & 570.00 & 10.88 & 85.91 & 1.27 \\
\hline$K L-24$ & 4.48 & 0.00 & 0.81 & 0.04 & 595.00 & 9.72 & 82.61 & 1.72 \\
\hline$K L-25$ & 6.36 & 0.00 & 1.09 & 0.06 & 588.00 & 8.66 & 97.39 & 1.11 \\
\hline$K L-26$ & 0.00 & 0.00 & 0.46 & 0.00 & 141.00 & 17.46 & 70.22 & 2.83 \\
\hline KL-27 & 3.84 & 0.00 & 0.71 & 0.00 & 239.00 & 13.81 & 69.21 & 1.20 \\
\hline$K L-28$ & 9.28 & 0.00 & 1.53 & 0.00 & 589.00 & 23.23 & 87.76 & 1.42 \\
\hline KL-29 & 3.40 & 0.00 & 0.60 & 0.03 & 451.00 & 9.84 & 52.48 & 0.82 \\
\hline$K L-30$ & 2.81 & 0.00 & 0.73 & 0.05 & 777.00 & 10.27 & 72.44 & 1.21 \\
\hline$K L-31$ & 5.87 & 0.00 & 0.99 & 0.04 & 723.00 & 11.30 & 72.76 & 1.12 \\
\hline$K L-32$ & 0.00 & 0.00 & 1.24 & 0.10 & 655.00 & 11.43 & 32.02 & 0.94 \\
\hline$K L-33$ & 16.27 & 0.00 & 1.51 & 0.05 & 677.00 & 13.24 & 49.39 & 1.20 \\
\hline$K L-34$ & 3.29 & 0.00 & 0.66 & 0.04 & 411.00 & 11.21 & 84.77 & 1.19 \\
\hline$K L-35$ & 4.65 & 0.00 & 0.95 & 0.05 & 640.00 & 10.89 & 85.19 & 1.23 \\
\hline$K L-36$ & 2.65 & 0.00 & 0.57 & 0.00 & 447.00 & 8.16 & 49.11 & 1.39 \\
\hline$K L-37$ & 3.39 & 0.00 & 0.42 & 0.05 & 230.00 & 0.00 & 43.14 & 1.35 \\
\hline$K L-38$ & 3.63 & 0.00 & 0.70 & 0.05 & 473.00 & 20.98 & 102.40 & 2.16 \\
\hline$K L-39$ & 4.29 & 0.00 & 0.77 & 0.04 & 641.00 & 11.38 & 81.14 & 1.10 \\
\hline$K L-40$ & 4.21 & 0.00 & 1.02 & 0.07 & 854.00 & 15.65 & 239.60 & 3.24 \\
\hline$K L-41$ & 4.66 & 0.00 & 0.97 & 0.00 & 682.00 & 0.00 & 91.68 & 0.00 \\
\hline$K L-42$ & 3.85 & 0.00 & 0.56 & 0.03 & 625.00 & 7.11 & 67.45 & 0.82 \\
\hline$K L-43$ & 4.10 & 0.00 & 0.77 & 0.05 & 507.00 & 10.11 & 70.89 & 1.23 \\
\hline $\mathrm{KL}-44$ & 3.15 & 0.00 & 0.99 & 0.00 & 472.00 & 0.00 & 115.10 & 0.00 \\
\hline
\end{tabular}


Sample

Name

Nd

$\mathrm{Zr}$

Co

\begin{tabular}{|c|c|c|c|c|c|c|c|c|}
\hline$K L-1$ & 16.75 & 0.08 & 18.00 & 3.00 & NR & & 14.90 & 0.40 \\
\hline$K L-2$ & 15.23 & 0.08 & 14.00 & 3.00 & NR & & 16.30 & 0.40 \\
\hline$K L-3$ & 12.25 & 0.06 & 17.00 & 2.00 & NR & & 16.80 & 0.40 \\
\hline $\mathrm{KL}-4$ & 9.98 & 0.05 & 15.00 & 2.00 & NR & & 14.10 & 0.30 \\
\hline$K L-5$ & 12.66 & 0.06 & 11.00 & 2.00 & NR & & 18.90 & 0.40 \\
\hline$K L-6$ & 15.37 & 0.08 & 13.00 & 3.00 & NR & & 24.80 & 0.50 \\
\hline$K L-7$ & 12.61 & 0.05 & 23.00 & 2.00 & NR & & 14.20 & 0.30 \\
\hline$K L-8$ & 11.66 & 0.05 & 23.48 & 0.96 & 219.10 & 28.67 & 13.22 & 0.27 \\
\hline$K L-9$ & 31.34 & 0.08 & 0.00 & 0.00 & 349.00 & 0.00 & 53.14 & 0.47 \\
\hline$K L-10$ & 15.46 & 0.06 & 28.32 & 2.40 & 127.40 & 30.37 & 19.21 & 0.32 \\
\hline$K L-11$ & 13.48 & 0.05 & 26.78 & 1.07 & 171.20 & 0.00 & 16.64 & 0.00 \\
\hline$K L-12$ & 14.18 & 0.05 & 31.19 & 1.03 & 157.60 & 34.92 & 19.56 & 2.50 \\
\hline$K L-13$ & 11.09 & 0.05 & 41.35 & 0.00 & 125.10 & 30.67 & 19.37 & 3.10 \\
\hline$K L-14$ & 19.74 & 0.07 & 0.00 & 0.00 & 223.40 & 54.87 & 20.53 & 2.40 \\
\hline$K L-15$ & 19.34 & 0.06 & 25.40 & 2.36 & 195.50 & 39.30 & 31.05 & 3.92 \\
\hline$K L-16$ & 16.22 & 0.06 & 34.13 & 0.00 & 205.90 & 35.44 & 19.15 & 4.54 \\
\hline$K L-17$ & 17.61 & 0.07 & 18.29 & 1.49 & 203.70 & 40.91 & 20.21 & 3.06 \\
\hline$K L-18$ & 18.66 & 0.06 & 19.37 & 2.30 & 0.00 & 0.00 & 30.61 & 3.58 \\
\hline$K L-19$ & 13.93 & 0.05 & 16.09 & 1.45 & 73.06 & 0.00 & 23.57 & 3.56 \\
\hline$K L-20$ & 13.85 & 0.06 & 16.11 & 0.00 & 130.50 & 29.15 & 27.63 & 4.68 \\
\hline$K L-21$ & 13.99 & 0.06 & 17.13 & 0.00 & 172.10 & 34.16 & 17.09 & 2.71 \\
\hline$K L-22$ & 16.74 & 0.05 & 25.51 & 2.59 & 208.50 & 46.45 & 30.04 & 0.00 \\
\hline$K L-23$ & 18.44 & 0.05 & 25.85 & 1.86 & 349.40 & 123.56 & 23.42 & 3.97 \\
\hline$K L-24$ & 15.61 & 0.04 & 46.49 & 0.00 & 189.60 & 30.72 & 21.61 & 3.18 \\
\hline$K L-25$ & 18.48 & 0.07 & 26.54 & 0.00 & 217.90 & 57.87 & 28.59 & 2.06 \\
\hline$K L-26$ & 23.81 & 0.07 & 21.13 & 0.00 & 256.90 & 0.00 & 6.39 & 0.00 \\
\hline$K L-27$ & 15.58 & 0.07 & 21.87 & 1.82 & 186.00 & 48.52 & 25.49 & 2.18 \\
\hline$K L-28$ & 19.42 & 0.08 & 48.74 & 1.25 & 330.70 & 70.27 & 45.89 & 4.35 \\
\hline$K L-29$ & 11.24 & 0.05 & 18.43 & 1.71 & 117.30 & 25.42 & 15.79 & 3.73 \\
\hline$K L-30$ & 15.73 & 0.06 & 17.69 & 1.61 & 189.30 & 31.32 & 21.08 & 0.00 \\
\hline$K L-31$ & 15.41 & 0.06 & 32.28 & 2.83 & 160.90 & 33.60 & 14.92 & 2.94 \\
\hline$K L-32$ & 12.74 & 0.06 & 50.31 & 4.35 & 167.10 & 29.36 & 21.03 & 2.97 \\
\hline$K L-33$ & 15.35 & 0.06 & 59.78 & 0.00 & 320.50 & 36.70 & 23.28 & 2.62 \\
\hline$K L-34$ & 20.12 & 0.07 & 28.26 & 1.88 & 235.80 & 31.27 & 8.49 & 0.00 \\
\hline$K L-35$ & 17.57 & 0.06 & 0.00 & 0.00 & 195.40 & 48.92 & 22.79 & 3.96 \\
\hline$K L-36$ & 11.28 & 0.04 & 0.00 & 0.00 & 156.50 & 49.98 & 24.54 & 3.75 \\
\hline$K L-37$ & 20.73 & 0.10 & 22.59 & 0.00 & 355.70 & 0.00 & 32.85 & 2.04 \\
\hline$K L-38$ & 22.85 & 0.08 & 0.00 & 0.00 & 164.60 & 44.95 & 38.12 & 2.88 \\
\hline$K L-39$ & 15.97 & 0.06 & 25.60 & 1.03 & 180.00 & 34.25 & 22.61 & 3.15 \\
\hline$K L-40$ & 32.49 & 0.09 & 0.00 & 0.00 & 335.60 & 128.29 & 42.89 & 2.98 \\
\hline$K L-41$ & 17.52 & 0.00 & 27.34 & 0.00 & 368.80 & 0.00 & 19.28 & 0.00 \\
\hline $\mathrm{KL}-42$ & 9.57 & 0.04 & 22.79 & 1.35 & 112.50 & 28.06 & 19.44 & 3.55 \\
\hline$K L-43$ & 19.56 & 0.07 & 20.24 & 2.11 & 232.90 & 62.77 & 24.07 & 3.2 \\
\hline$K L-44$ & 23.09 & 0.00 & NR & & 189.70 & 0.00 & 24.55 & 0.00 \\
\hline
\end{tabular}


Sample

Name

$\mathrm{Fe}^{*}$

$\mathrm{Na}^{*}$

$K^{*}$

$\begin{array}{lrlllll}K L-1 & 3.57 & 0.04 & 0.95 & 0.00 & 0.69 & 0.11 \\ \text { KL-2 } & 3.39 & 0.04 & 0.93 & 0.00 & 0.79 & 0.12 \\ \text { KL-3 } & 4.50 & 0.04 & 2.54 & 0.01 & 0.93 & 0.18 \\ \text { KL-4 } & 3.43 & 0.03 & 2.92 & 0.01 & 1.30 & 0.20 \\ \text { KL-5 } & 4.10 & 0.04 & 2.66 & 0.01 & 0.87 & 0.16 \\ \text { KL-6 } & 5.22 & 0.05 & 2.66 & 0.01 & 0.88 & 0.18 \\ \text { KL-7 } & 3.11 & 0.03 & 1.26 & 0.00 & 1.90 & 0.20 \\ \text { KL-8 } & 4.20 & 0.19 & 2.39 & 0.00 & 1.39 & 0.00 \\ \text { KL-9 } & 9.19 & 0.25 & 1.75 & 0.00 & 0.37 & 0.00 \\ \text { KL-10 } & 5.01 & 0.17 & 0.95 & 0.00 & 1.84 & 0.00 \\ \text { KL-11 } & 2.10 & 0.15 & 0.89 & 0.00 & 2.02 & 0.00 \\ \text { KL-12 } & 4.58 & 0.20 & 1.09 & 0.00 & 1.89 & 0.00 \\ \text { KL-13 } & 4.19 & 0.22 & 1.69 & 0.00 & 1.52 & 0.00 \\ \text { KL-14 } & 6.47 & 0.15 & 7.12 & 0.00 & 1.36 & 0.00 \\ \text { KL-15 } & 5.96 & 0.18 & 1.01 & 0.00 & 0.70 & 0.00 \\ \text { KL-16 } & 4.51 & 0.23 & 1.09 & 0.00 & 1.58 & 0.00 \\ \text { KL-17 } & 4.16 & 0.18 & 1.11 & 0.00 & 1.53 & 0.00 \\ \text { KL-18 } & 5.46 & 0.22 & 1.24 & 0.00 & 1.19 & 0.00 \\ \text { KL-19 } & 5.07 & 0.20 & 2.99 & 0.00 & 1.13 & 0.00 \\ \text { KL-20 } & 4.64 & 0.20 & 3.05 & 0.00 & 1.21 & 0.00 \\ \text { KL-21 } & 5.09 & 0.26 & 0.93 & 0.00 & 0.84 & 0.00 \\ \text { KL-22 } & 8.77 & 0.22 & 0.95 & 0.00 & 1.13 & 0.00 \\ \text { KL-23 } & 5.69 & 0.31 & 1.38 & 0.00 & 1.42 & 0.00 \\ \text { KL-24 } & 4.63 & 0.19 & 1.09 & 0.00 & 1.41 & 0.00 \\ \text { KL-25 } & 4.81 & 0.20 & 0.95 & 0.00 & 0.61 & 0.00 \\ \text { KL-26 } & 11.08 & 0.10 & 0.06 & 0.01 & 0.00 & 0.00 \\ \text { KL-27 } & 6.09 & 0.21 & 0.44 & 0.00 & 0.54 & 0.00 \\ \text { KL-28 } & 6.94 & 0.26 & 0.62 & 0.00 & 0.42 & 0.00 \\ \text { KL-29 } & 3.18 & 0.15 & 1.19 & 0.00 & 1.39 & 0.00 \\ \text { KL-30 } & 4.67 & 0.21 & 0.99 & 0.00 & 1.84 & 0.00 \\ \text { KL-31 } & 4.46 & 0.19 & 0.98 & 0.00 & 1.63 & 0.00 \\ \text { KL-32 } & 3.34 & 0.23 & 1.03 & 0.00 & 1.71 & 0.00 \\ \text { KL-33 } & 4.01 & 0.16 & 0.42 & 0.00 & 1.40 & 0.00 \\ \text { KL-34 } & 4.84 & 0.09 & 0.10 & 0.00 & 0.61 & 0.00 \\ \text { KL-35 } & 3.82 & 0.22 & 1.24 & 0.00 & 1.56 & 0.00 \\ \text { KL-36 } & 4.12 & 0.18 & 3.22 & 0.00 & 0.86 & 0.00 \\ \text { KL-37 } & 6.01 & 0.14 & 0.06 & 0.00 & 0.00 & 0.00 \\ \text { KL-38 } & 8.26 & 0.20 & 0.50 & 0.00 & 0.88 & 0.00 \\ \text { KL-39 } & 4.92 & 0.20 & 1.17 & 0.00 & 1.39 & 0.00 \\ \text { KL-40 } & 7.91 & 0.18 & 0.56 & 0.00 & 0.60 & 0.00 \\ \text { KL-41 } & 4.68 & 0.00 & 1.19 & 0.00 & 1.46 & 0.00 \\ \text { KL-42 } & 3.16 & 0.20 & 1.47 & 0.00 & 1.55 & 0.00 \\ \text { KL-43 } & 5.74 & 0.31 & 1.95 & 0.00 & 0.64 & 0.00 \\ \text { KL-44 } & 5.53 & 0.00 & 1.08 & 0.00 & 0.58 & 0.00 \\ & & & & & & \end{array}$

"Elemental values reported in percent 
Sample Sample

$\begin{array}{lclllllr}\text { Name } & \text { Number } & \text { Location } & \text { Unit } & \mathrm{SiO}_{2} & \mathrm{Al}_{2} \mathrm{Q}_{3} & \mathrm{TiO}_{2} & \mathrm{FeO}^{*} \\ \mathrm{KL}-2 & 2 & \text { 2S/4E-8BAA } & \text { Ttus } & 61.37 & 26.27 & 1.47 & 5.90 \\ \mathrm{KL}-3 & 3 & \text { 2S/3E-1ACD } & \text { QTs } & 60.43 & 17.56 & 1.08 & 6.89 \\ \mathrm{KL}-5 & 5 & \text { 2S/3E-1BBA } & \text { QTv } & 58.04 & 18.98 & 0.99 & 6.42 \\ \mathrm{KL}-7 & 7 & \text { 2S/3E-14CAB } & \text { TtI } & 68.97 & 16.95 & 1.02 & 5.08 \\ \mathrm{KL}-8 & 8 & \text { 2S/3E-1CAA } & \text { Ttu } & 62.99 & 21.08 & 0.88 & 5.64 \\ \mathrm{KL}-9 & 9 & \text { 2S/3E-1CCB } & \text { Ttus } & 50.51 & 16.45 & 1.30 & 12.33 \\ \mathrm{KL}-10 & 10 & \text { 2S/3E-1CCB } & \text { Ttuc } & 66.80 & 17.67 & 0.87 & 7.23 \\ \mathrm{KL}-11 & 11 & \text { 2S/3E-1CCB } & \text { Ttuc } & 68.85 & 20.39 & 1.00 & 2.84 \\ \mathrm{KL}-12 & 12 & \text { 2S/3E-1CCB } & \text { Ttuc } & 69.93 & 15.85 & 0.88 & 6.10 \\ \mathrm{KL}-16 & 16 & \text { 2S/4E-7BDC } & \text { TtI } & 67.87 & 17.07 & 1.02 & 6.21 \\ \mathrm{KL}-19 & 19 & \text { 2S/4E-8BAA } & \text { QTv } & 59.84 & 17.92 & 0.97 & 6.00 \\ \mathrm{KL}-26 & 26 & \text { 2S/5E-31BBA } & \text { TtI } & 35.73 & 37.63 & 3.33 & 21.81 \\ \mathrm{KL}-28 & 28 & \text { 2S/4E-7DBA } & \text { Ttus } & 58.27 & 25.30 & 1.44 & 11.00 \\ \mathrm{KL}-30 & 30 & \text { 2S/4E-18AAC } & \text { Ttu } & 69.08 & 17.17 & 0.92 & 6.08 \\ \mathrm{KL}-31 & 31 & \text { 2S/4E-18ABD } & \text { Ttuc } & 70.15 & 15.54 & 0.88 & 6.70 \\ \mathrm{KL}-32 & 32 & \text { 2S/4E-28AAB } & \text { Ttu } & 72.81 & 15.85 & 0.90 & 4.71 \\ \mathrm{KL}-33 & 33 & \text { 2S/4E-28AAB } & \text { Ttuc } & 71.26 & 16.42 & 1.35 & 6.08 \\ \mathrm{KL}-36 & 36 & \text { 1S/4E-36ABA } & \text { QTs } & 62.30 & 17.20 & 0.79 & 5.60 \\ \mathrm{KL}-37 & 37 & \text { 1S/3E-26ABD } & \text { QTv } & 54.48 & 33.53 & 1.48 & 9.61 \\ \mathrm{KL}-38 & 38 & \text { 2S/4E-10DBC } & \text { QTs } & 54.94 & 26.53 & 1.96 & 12.36 \\ \mathrm{KL}-45 & 45 & \text { 1S/4E-35BCB } & \text { QTb } & 49.59 & 16.76 & 1.42 & 11.19 \\ \mathrm{KL}-46 & 46 & \text { 1S/4E-35BCB } & \text { Ttus } & 51.23 & 16.93 & 1.35 & 11.26 \\ \mathrm{KL}-47 & 47 & \text { 1S/4E-27ADD } & \text { Ttus } & 50.17 & 17.05 & 1.52 & 11.71 \\ \mathrm{KL}-48 & 48 & \text { 2S/4E-8BAA } & \text { Ttus } & 56.75 & 16.94 & 1.22 & 8.41 \\ \mathrm{KL}-49 & 49 & \text { 2S/4E-8BAA } & \text { Ttus } & 52.30 & 16.87 & 1.44 & 11.41 \\ \mathrm{KL}-50 & 50 & \text { 2S/3E-11BDA } & \text { Ttus } & 51.02 & 17.09 & 1.46 & 11.14\end{array}$

*Total $\mathrm{Fe}$ is expressed as $\mathrm{FeO}$ 
Sample

\begin{tabular}{|c|c|c|c|c|c|c|}
\hline Name & $\mathrm{MnO}$ & $\mathrm{CaO}$ & $\mathrm{MgO}$ & $\mathrm{K}_{2} \mathrm{O}$ & $\mathrm{Na}_{2} \mathrm{O}$ & $\mathrm{P}_{2} \mathrm{O}_{5}$ \\
\hline$K L-2$ & 0.03 & 1.34 & 0.63 & 1.22 & 1.75 & 0.04 \\
\hline$K L-3$ & 0.09 & 5.71 & 2.68 & 1.30 & 4.06 & 0.21 \\
\hline $\mathrm{KL}-5$ & 0.11 & 6.29 & 3.73 & 0.98 & 4.32 & 0.16 \\
\hline$K L=7$ & 0.04 & 1.62 & 1.47 & 2.55 & 2.18 & 0.13 \\
\hline$K L-8$ & 0.04 & 3.19 & 0.47 & 1.84 & 3.81 & 0.07 \\
\hline$K L-9$ & 0.29 & 8.65 & 7.53 & 0.20 & 2.64 & 0.10 \\
\hline$K L-10$ & 0.03 & 1.01 & 1.83 & 2.94 & 1.57 & 0.05 \\
\hline$K L-11$ & 0.02 & 0.88 & 1.20 & 3.34 & 1.46 & 0.03 \\
\hline$K L-12$ & 0.03 & 1.27 & 1.48 & 2.60 & 1.82 & 0.05 \\
\hline$K L-16$ & 0.05 & 1.66 & 1.72 & 2.46 & 1.82 & 0.11 \\
\hline$K L-19$ & 0.10 & 6.15 & 2.95 & 1.34 & 4.54 & 0.20 \\
\hline$K L-26$ & 0.27 & 0.78 & 0.00 & 0.06 & 0.09 & 0.30 \\
\hline$K L-28$ & 0.06 & 1.15 & 0.81 & 0.73 & 1.20 & 0.04 \\
\hline$K L-30$ & 0.03 & 0.71 & 1.48 & 2.82 & 1.66 & 0.05 \\
\hline$K L-31$ & 0.04 & 1.12 & 1.38 & 2.38 & 1.79 & 0.03 \\
\hline$K L-32$ & 0.07 & 0.65 & 0.87 & 2.42 & 1.69 & 0.03 \\
\hline$K L-33$ & 0.06 & 0.38 & 1.02 & 2.59 & 0.79 & 0.04 \\
\hline$K L-36$ & 0.08 & 5.02 & 2.53 & 1.53 & 4.75 & 0.18 \\
\hline$K L-37$ & 0.14 & 0.18 & 0.14 & 0.07 & 0.28 & 0.08 \\
\hline$K L-38$ & 0.13 & 0.46 & 1.02 & 1.33 & 1.09 & 0.18 \\
\hline$K L-45$ & 0.17 & 9.84 & 7.62 & 0.29 & 2.94 & 0.13 \\
\hline$K L .46$ & 0.17 & 9.33 & 6.12 & 0.27 & 3.03 & 0.11 \\
\hline $\mathrm{KL}-47$ & 0.16 & 8.85 & 7.13 & 0.32 & 2.71 & 0.13 \\
\hline$K L-48$ & 0.13 & 7.23 & 4.36 & 1.38 & 3.39 & 0.17 \\
\hline$K L-49$ & 0.15 & 8.23 & 6.24 & 0.46 & 2.71 & 0.12 \\
\hline$K L-50$ & 0.16 & 9.22 & 6.30 & 0.42 & 3.01 & 0.16 \\
\hline
\end{tabular}


APPENDIX B

STRATIGRAPHIC SECTIONS OF SAMPLED WELLS 


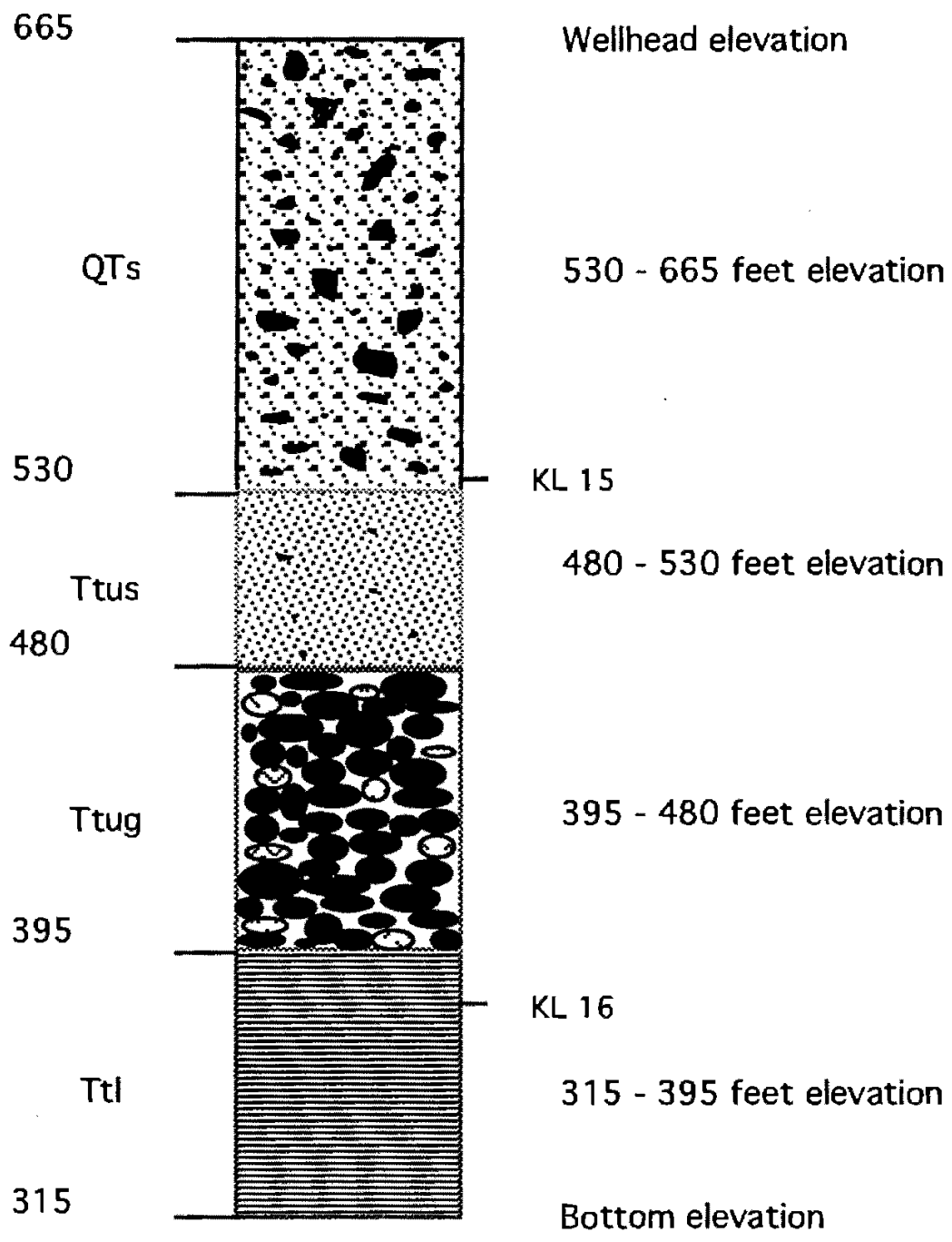

Figure 26. Snyder well section. Located in T2S/R4E, section 7BDC. 
541

469

Ttus

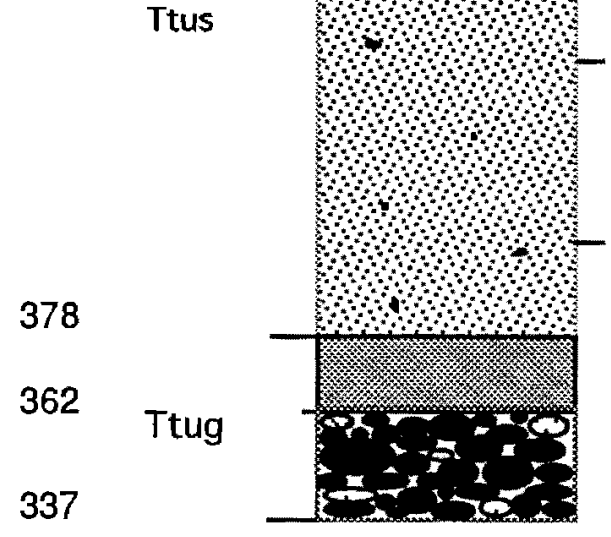

Wellhead elevation

469-541 feet elevation

$\mathrm{KL} 44$

362-469 feet elevation

KL 50

KL 18

337-362 feet elevation

Bottom elevation

Figure 27. Wilson well section. Located in T2S/R3E, section 11BDA. 


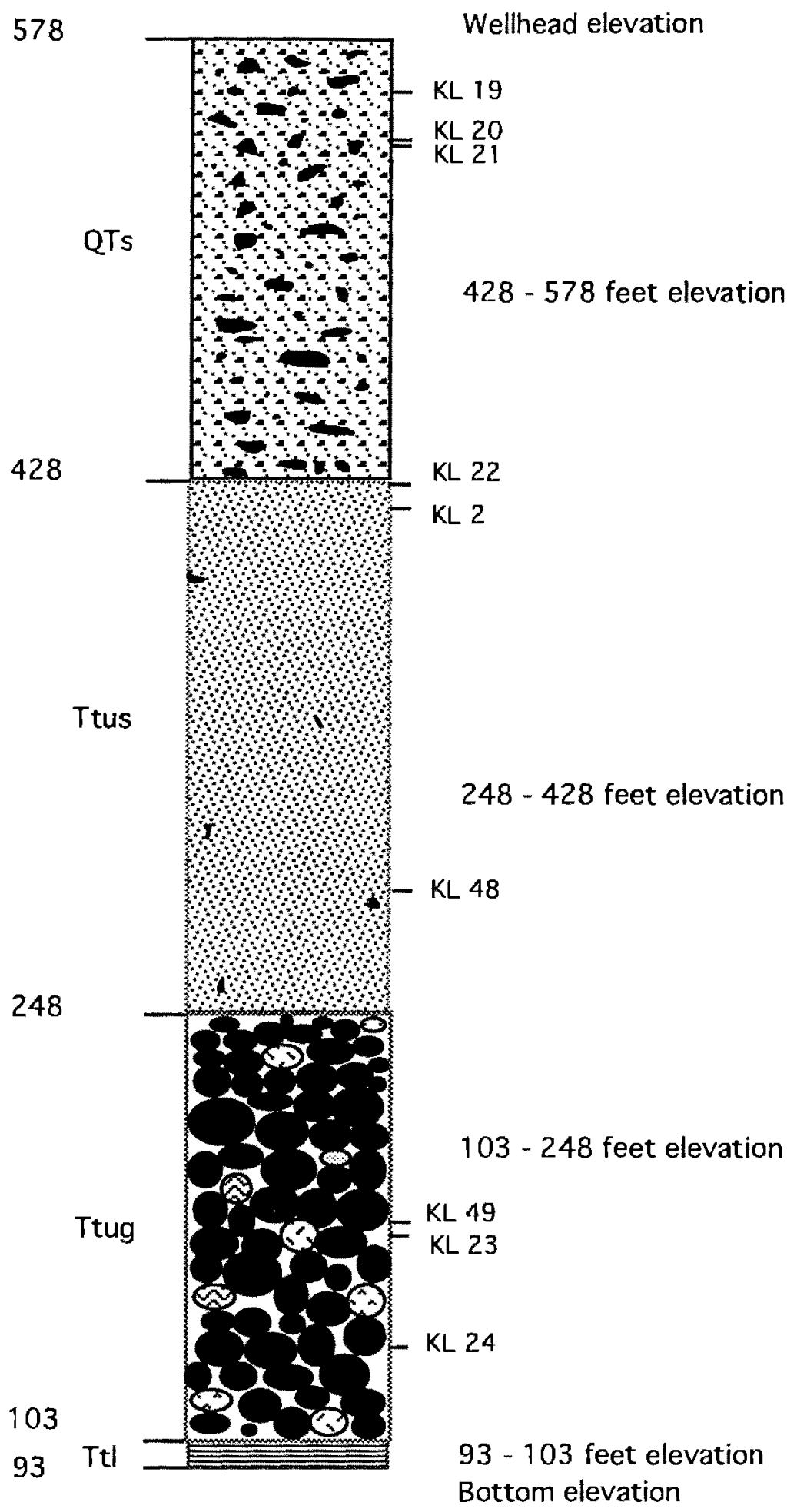

Figure 28. Iseli Nursery well \#6 section. Located in T2S/R4E, section 8BAA. 
700

480

400

210

200

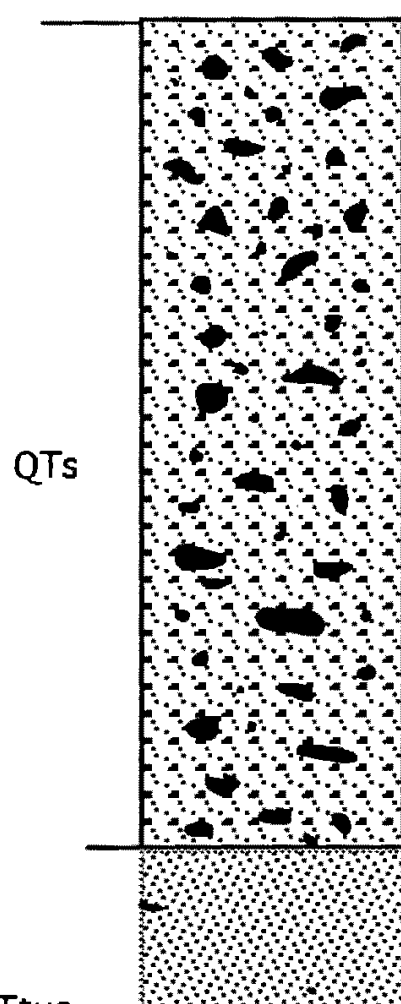

Ttus
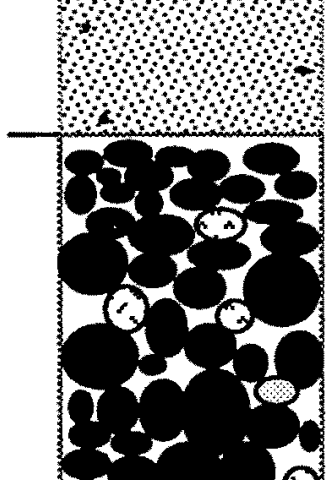

Ttug

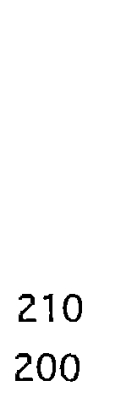

Wellhead elevation

480-700 feet elevation

400-480 feet elevation

210-400 feet elevation

200 - 210 feet elevation

Bottom elevation

Figure 29. Surface Nursery well section. Located in T1S/R4E, section 27ADD. 


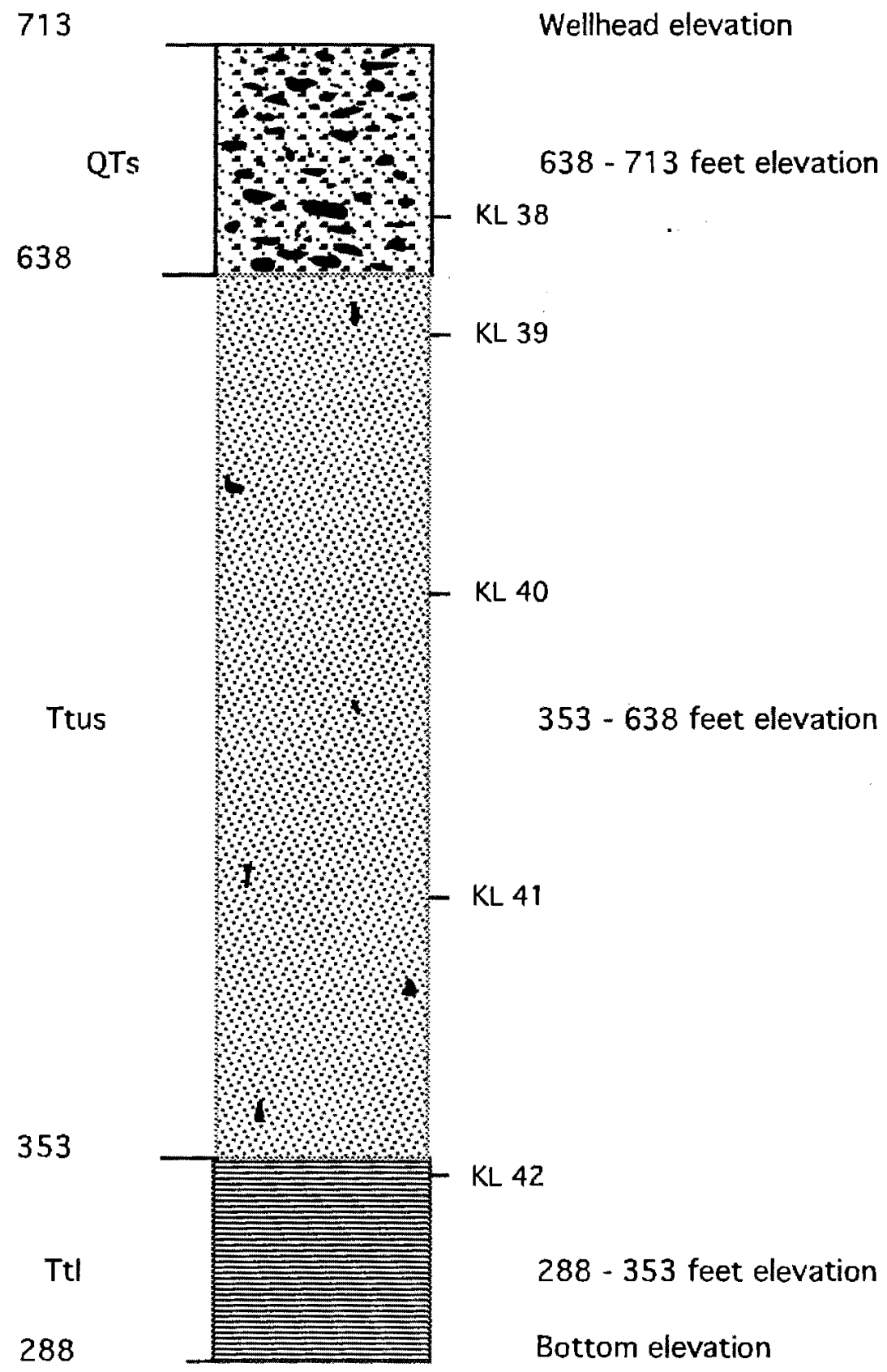

Figure 30. Sobella Nursery well section. Located in T2S/R4E, section 1ODBC. 
740

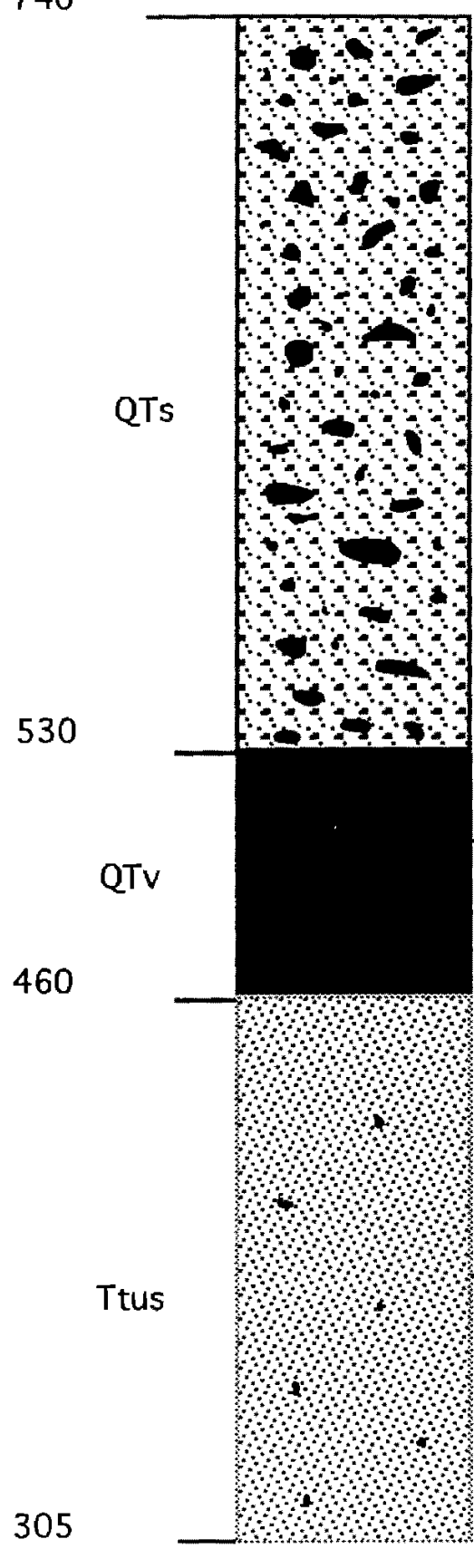

Wellhead elevation

530 - 740 feet elevation

$\mathrm{KL} 45$

530 - 460 feet elevation
$\mathrm{KL} 46$

460 - 305 feet elevation

Bottom elevation

Figure 31 . Krueger Nursery well section. Located in T1S/R4E, section 35BCB. 